UNIVERSIDADE DE SÃO PAULO

FACULDADE DE ECONOMIA, ADMINISTRAÇÃO E CONTABILIDADE DEPARTAMENTO DE ADMINISTRAÇÃO

PROGRAMA DE MESTRADO PROFISSIONAL EM EMPREENDEDORISMO

ORGANISMOS ESTUDANTIS E O INCENTIVO AO EMPREENDEDORISMO NAS UNIVERSIDADES BRASILEIRAS

Artur Tavares Vilas Boas Ribeiro

Orientador: Prof. Dr. Guilherme Ary Plonski

SÃO PAULO

2016 
Prof. Dr. Marco Antônio Zago

Reitor da Universidade de São Paulo

Prof. Dr. Adalberto Américo Fischmann

Diretor da Faculdade de Economia, Administração e Contabilidade

Prof. Dr. Roberto Sbragia

Chefe do Departamento de Administração

Prof. Dr. Martinho Isnard Ribeiro de Almeida

Coordenador do Programa de Mestrado Profissional em Empreendedorismo 


\title{
ORGANISMOS ESTUDANTIS E O INCENTIVO AO EMPREENDEDORISMO NAS UNIVERSIDADES BRASILEIRAS
}

\author{
Dissertação apresentada ao Departamento \\ de Administração da Faculdade de \\ Economia, Administração e Contabilidade \\ da Universidade de São Paulo como registro \\ parcial para obtenção do título de Mestre em \\ Ciências.
}

Orientador: Prof. Dr. Guilherme Ary Plonski 
FICHA CATALOGRÁFICA

Elaborada pela Seção de Processamento Técnico do SBD/FEA/USP

Ribeiro, Artur Tavares Vilas Boas.

Organismos estudantis e o incentivo ao empreendedorismo nas universidades brasileiras / Artur Tavares Vilas Boas Ribeiro. - São Paulo, 2016.

$112 \mathrm{p}$.

Dissertação (Mestrado) - Universidade de São Paulo, 2016.

Orientador: Guilherme Ary Plonski.

1. Empreendedorismo. 2. Universidade. 3. Entidades estudantis. 4.

Criação de empresas. I. Universidade de São Paulo. Faculdade de Economia, Administração e Contabilidade. II. Título. 
Aos professores Ary e Zancul, pelas oportunidades, conhecimento e inspiração inequívocos.

A todos envolvidos com o Núcleo de Empreendedorismo da USP, pela confiança, suporte, paciência e resiliência.

À minha família e aos que compuseram parte da minha jornada, por fazer de mim alguém com tantos privilégios para perseguir utopias. 

"Contar é muito dificultoso. Não pelos anos que já se passaram. Mas pela astúcia que tem certas coisas passadas de fazer balancê, de se remexerem dos lugares. A lembrança da vida da gente se guarda em trechos diversos; uns com os outros acho que nem se misturam [...]. Contar seguido, alinhavado, só mesmo sendo coisas de rasa importância.". Se para Guimarães Rosa era difícil o "resgate da alma em cuja memória se encontram as coisas eternas", percebo dificuldade maior neste momento de colocar em uma folha minhas muitas palavras de agradecimento. Os motivadores diversos que me cabem agradecer me fariam escrever uma outra dissertação. Guimarães estava certo, contar é muito dificultoso.

Inicialmente, agradeço aos que me criaram e me deram condições materiais, intelectuais e morais para o cumprimento de minhas missões: meus pais, Artur, Carmem e Antônio, além de minha irmã Raquel. E à Bárbara, por me mostrar melhores caminhos.

Ao grande mestre e orientador que tive prazer de encontrar nessa jornada, professor Ary, por ter me ensinado (e continuar ensinando) muito mais que pesquisar, lecionar ou estimular o empreendedorismo em instituições de pesquisa. Mas por me ensinar a carregar em cada ação a essência de Tikkun Olam, de consertar o mundo. E, representados pelo professor Ary, agradeço a tantos outros professores que marcaram minha vida e reforçaram em mim o sonho de ser como eles.

Aos acadêmicos empreendedores que compartilham do mesmo sonho e tentam construir organizações e elementos de transformação dentro das instituições em que estão inseridos, Eduardo Zancul, Marcos Barretto, Alessandro Moreira, Paulo Lemos, Patrícia Krakauer, Fábio Kon, André Fleury, César Guimarães, Taiguara Langrafe, Roseli Lopes, João Bittencourt, Alexandre Martinazzo, Glauco Peres, Edison Simoni, Anapatrícia Morales e tantos outros.

Aos alunos empreendedores da USP que confiaram nos meus sonhos e projetos, que estiveram presentes e que me ajudaram nessa construção. Aos que fizeram parte do Núcleo de Empreendedorismo da USP e passaram por desafios de maneira nobre, corajosa e resiliente. Aos que à frente da organização estiveram do meu lado, aos que pavimentaram muito dela anteriormente, aos que estão construindo as bases para o futuro: essa construção é de vocês. Aos parceiros, apoiadores e patrocinadores dos nossos esforços, muito obrigado.

Aos envolvidos nos movimentos de incentivo aos ecossistemas de empreendedorismo, aos que tentam construir outras organizações grassroots e diariamente buscam transformar os ambientes onde estão inseridos, agradeço por toda inspiração e cumplicidade.

Aos amigos, familiares e colegas, obrigado por suportar minhas excentricidades. À toda equipe Wylinka, por confiar e permitir meu desenvolvimento livre na missão de transbordar todos os sonhos e ideais - um agradecimento especial à Ana e ao Elimar, por me acolherem e acreditarem em mim.

Muito obrigado a todos que compuseram minha jornada. Muito obrigado. 

"Qual a juventude mais desafiada? A do século anterior ou aquela que hoje se empenha na construção do futuro? Cada geração enfrenta desafios que lhe são próprios. Em cada época, em cada cidade, país ou continente, há problemas percebidos ou ignorados. Percebidos por quem se dispõe a fazer a diferença; ignorados por quem se entrega exclusivamente ao próprio cotidiano ou sucumbe às tentações da inércia. Esta inércia, felizmente, em todas as circunstâncias enfrentou a virtuosa resistência dos que buscam soluções, espaços de poder e resultados como instrumentos para a viabilização de ideias que melhorem a vida coletiva." 



\section{RESUMO}

O presente estudo tem como proposta compreender os processos de nascimento e evolução de organizações estudantis que atuam no incentivo ao empreendedorismo em universidades de pesquisa brasileiras. A característica central de tais organizações é relativa ao seu modelo grassroots: de gênese espontânea e informal, autônoma de interesses institucionais e com crescimento de baixo para cima - partindo dos alunos e ganhando apoio institucional ao passo que amadurecem seus trabalhos. Pretendeu-se explorar com maior profundidade os seguintes elementos acerca das mesmas: (i) surgimento e motivações; (ii) papéis e atividades a serem desempenhadas; (iii) indicadores de maturidade. A revisão de literatura cobriu inicialmente o conceito de empreendedorismo e seu impacto econômico, avançando para a abordagem de ecossistemas de empreendedorismo, detalhando os papéis das universidades em ecossistemas e modelos práticos para tais e, por fim, deu ênfase e aprofundamento nas bibliografias relativas ao fenômeno das organizações universitárias grassroots para empreendedorismo. A pesquisa tem caráter exploratório e abordagem qualitativa, utilizando, como método o estudo de casos múltiplos com fonte de coleta complementar por dois elementos: um relato descritivo com observador participante e um levantamento de experiências. O relato descritivo apresentou a vivência do observador participante atuando à frente do Núcleo de Empreendedorismo da USP, trazendo percepções acerca de desafios, soluções e atividades desempenhadas pela organização. $\mathrm{O}$ levantamento de experiência contou com entrevistas em profundidade aplicadas em dez líderes ou ex-líderes de organizações grassroots de universidades de pesquisa brasileiras. As entrevistas se dividiram em três blocos: papéis a serem desempenhados; criação e organização do movimento; validação de um modelo de maturidade. O Modelo de Maturidade se baseou em um modelo proposto por uma associação nacional de organizações grassroots para empreendedorismo em universidades do Reino Unido, buscando validação e adaptação ao contexto de universidades de pesquisa brasileiras resultando em um modelo com quatro estágios: nascente, em consolidação, maduro e autossustentável. O tratamento dos dados das entrevistas foi realizado por meio de Análise de Conteúdo, utilizando os procedimentos de Bardin. Os resultados obtidos dialogam com a teoria e reforçam a importância das organizações grassroots no direcionamento estratégico das universidades, bem como sua relevância quanto à capacidade de execução e transformação do ambiente universitário. Referente às atividades, pode-se perceber uma concentração em três vias: inspiração/estímulo; capacitação/ensino; conexão/estrutura. $\mathrm{O}$ incentivo ao aluno interessado em empreender, percorrendo essas vias, se encerra com a formação de empreendedores que, bem-sucedidos, retornam à universidade trazendo consigo inspiração, capacitação e conexões para novos alunos interessados, formando uma espiral positiva e um efeito de rede marcante no estudo. Faz-se importante ressaltar também a notada tensão entre o apoio institucional salutar que pode vir a ser dado pela universidade versus os riscos de fagocitose, institucionalização prejudicial e engessamento das organizações grassroots. Deste modo, este estudo busca contribuir trazendo maior compreensão sobre o fenômeno grassroots e dar suporte a tais organismos e às instituições em que se inserem na otimização de suas atividades em universidades de pesquisa brasileira. Sua relevância se faz pelo relativo ineditismo no contexto nacional, pelo potencial impacto de tais organismos e pela contemporaneidade do fenômeno, abrindo caminhos para futuros e aprofundados estudos.

Palavras-chave: Empreendedorismo, Universidades, Entidades estudantis, Criação de empresas 


\section{ABSTRACT}

This study has the purpose to understand the processes of birth and evolution of student-led organizations active in encouraging entrepreneurship in Brazilian research universities. The central feature of such organizations is related to its grassroots model of spontaneous and informal genesis, autonomous institutional interests and bottom-up rising - starting with students and gaining institutional support while they mature their jobs. It was intended to explore in greater depth the following about them: (i) emergence and motivations; (ii) roles and activities to be performed; (Iii) indicators of maturity. The literature review originally covered the concept of entrepreneurship and its economic impact, advancing to entrepreneurship ecosystems, detailing the roles of universities in ecosystems and practical models for such, and, finally, has emphasized and deepen in the bibliographies about the phenomenon of grassroots university organizations for entrepreneurship. The research has an exploratory and qualitative approach, using a Multiple Case Study and using data from two elements: a descriptive report with participant observer and an experience description. The descriptive report presented the experience of the participant observer acting ahead of the USP Entrepreneurship Center (studen-led organization), bringing insights about challenges, solutions and activities performed. The experience description had in-depth interviews applied with ten leaders or former leaders of grassroots organizations from Brazilian research universities. The interviews were divided into three groups: roles to be played; creation and organization of the movement; validation of a maturity model. The Maturity Model is based on a proposed by a model from a national association of grassroots organizations for entrepreneurship in UK universities, seeking validation and adaptation to the context of Brazilian research universities - resulting in a model with four stages: borning, in consolidation, mature and self-sustaining. The treatment of the interviews data was conducted through content analysis, using the Bardin procedures. The results obtained dialogue with theory and reinforce the importance of grassroots organizations in the strategic direction of the universities as well as their relevance for get things done and transformation of the university environment. On the activities, one can see a concentration in three ways: inspiration; training; connection/structure. The motivation of students interested in being a entrepreneur, traveling these roads, ends with the formation of successful entrepreneurs that returns to the university bringing inspiration, training and connections to new interested students, forming a outstanding positive spiral and network effect in the study. It is also important to emphasize a perceived tension between the healthy institutional support that can be gived by the university versus the risks of phagocytosis, harmful institutionalization and inflexibility of grassroots organizations. Thus, this study seeks to contribute by bringing greater understanding of the phenomenon and support such organizations and institutions to which they belong in optimizing their activities in Brazilian research universities. Its relevance is done by the relative novelty in the national context, the potential impact of such bodies and the phenomenon of contemporaneity, opening for future paths and in-depth studies.

Keywords: Entrepreneurship, Student-led organizations, Universities, Company creation. 



\section{SUMÁRIO}

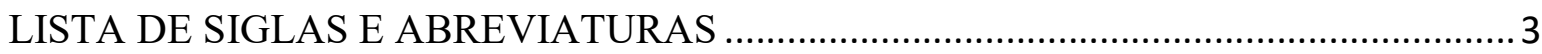

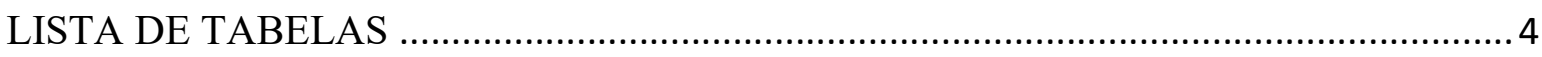

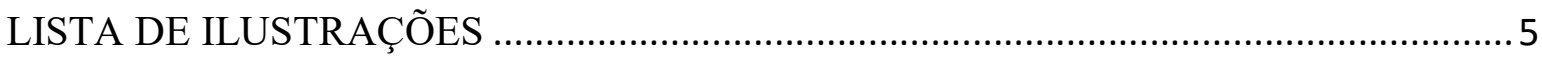

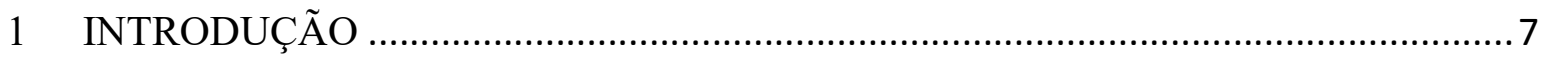

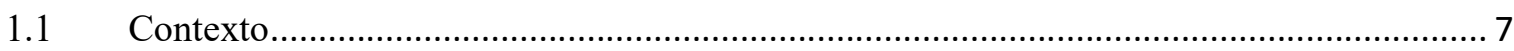

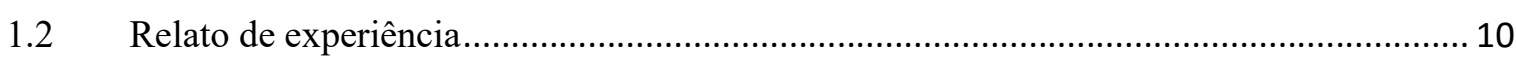

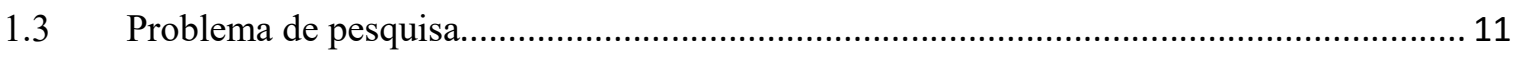

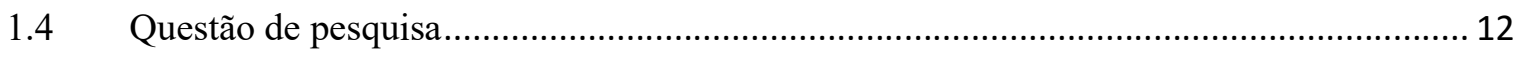

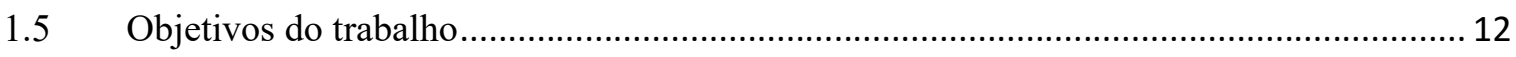

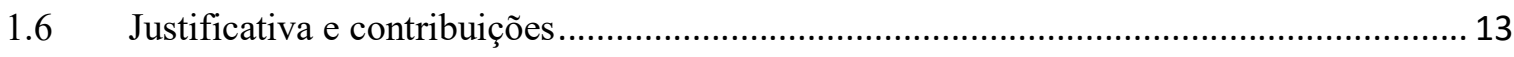

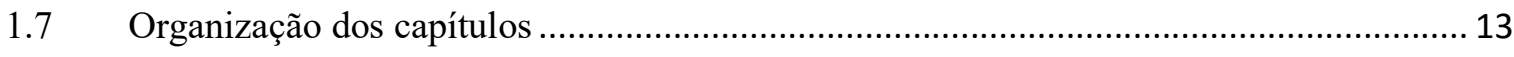

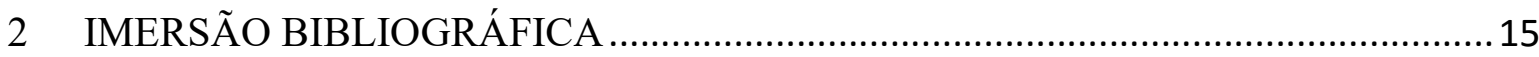

2.1 Empreendedorismo e seu impacto econômico................................................................... 15

$2.2 \quad$ O conceito de ecossistemas de empreendedorismo ........................................................... 16

2.3 O papel da universidade em ecossistemas de empreendedorismo ...................................... 19

2.3.1 Estudos relativos ao papel da universidade como efetiva no incentivo ao

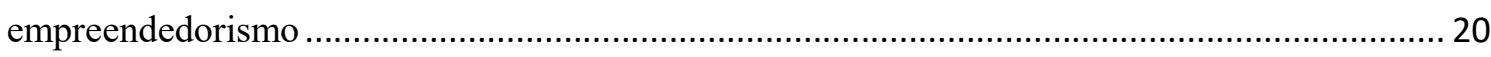

2.3.2 Modelos internacionais de universidades e ecossistemas de empreendedorismo ......... 24

2.4 A transformação da universidade rumo ao empreendedorismo por meio dos movimentos

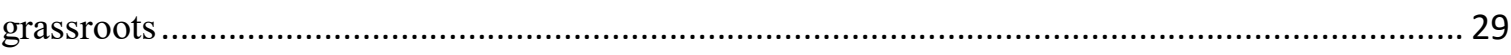

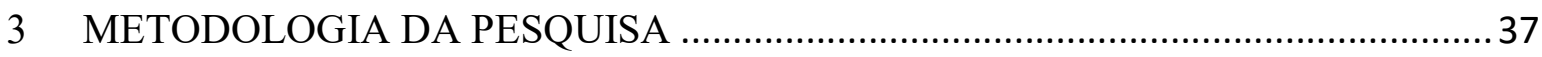

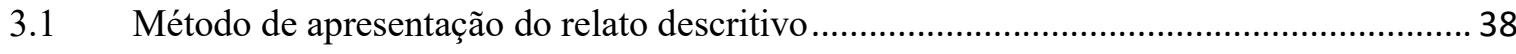

3.2 Método no tratamento de dados do levantamento de experiências....................................... 39

3.3 Matriz de amarração da dissertação ................................................................................ 41

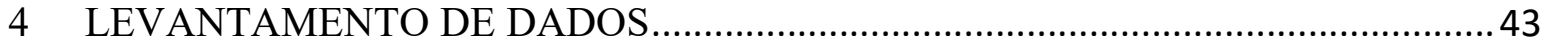

4.1 Relato Descritivo: Núcleo de Empreendedorismo da USP............................................... 43

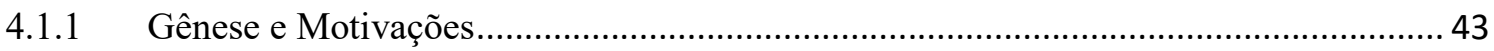

4.1.2 Estrutura organizacional e de operações …................................................................ 47

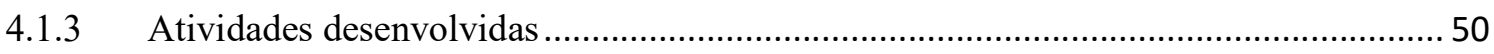

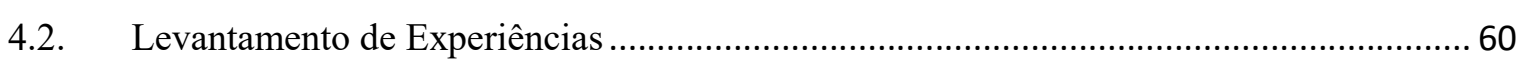

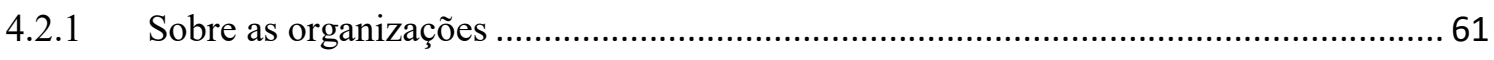

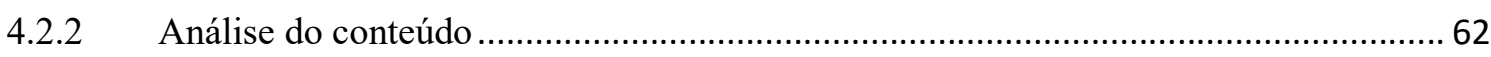




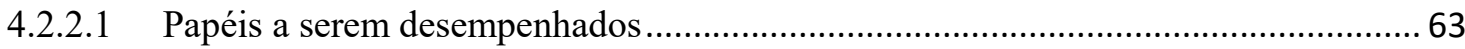

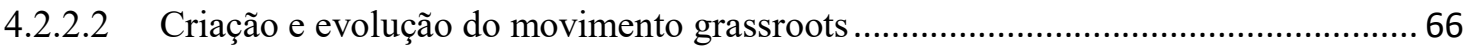

4.2.2.3 Validação do Modelo de Maturidade NACUE ............................................................. 76

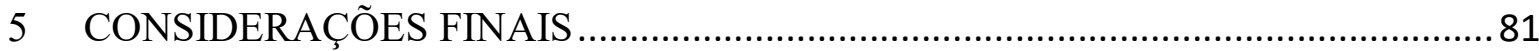

5.1 Da prática à teoria: relações identificadas no referencial teórico …................................... 81

5.2 Estrutura de atividades e métricas das organizações ........................................................ 83

5.3 Modelo de Maturidade para organizações estudantis grassroots voltadas para

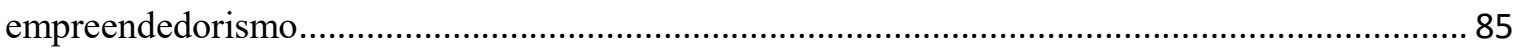

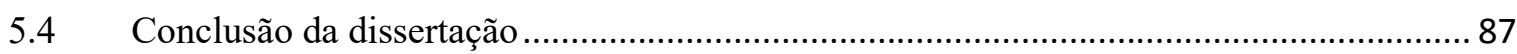

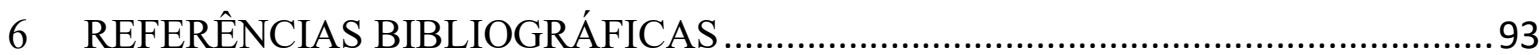

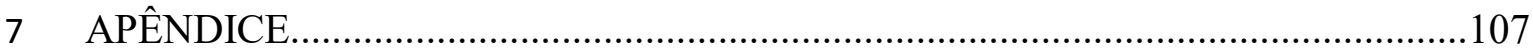




\section{LISTA DE SIGLAS E ABREVIATURAS}

AALTOES

AEP

AWC

AUSPIN

BRICs

CCSL/USP

CEO

CEU

EUA

FEA/USP

FEA-RP/USP

GEM

HP

IME/USP

MIT

MOOC

MOVER

MVP

NACUE

NEU

PGT/USP

PICE

Poli/USP

PRP/USP

RUNN

SEBRAE

UNICAMP

UNIFEI

USP
Aalto Entrepreneurship Society

Associação dos Engenheiros Politécnicos

Academic Working Capital

Agência USP de Inovação

Brasil, Rússia, Índia e China

Centro de Competência de Software Livre da USP

Chief Executive Officer ou diretor executivo

Centro de Empreendedorismo da UNIFEI

Estados Unidos da América

Faculdade de Economia, Administração e

Contabilidade da USP

Faculdade de Economia, Administração e

Contabilidade da USP de Ribeirão Preto

Global Entrepreneurship Monitor

Hewllet-Packard Company

Instituto de Matématica e Estatística da USP

Massachussets Institute of Technology

Massive Open Online Course

Movimento Empreende Ribeirão

Minimum Viable Product ou Produto Mínimo Viável

National Consortium of University Entrepreneurs

Núcleo de Empreendedorismo da USP

Núcleo de Política e Gestão Tecnológica da USP

Programa Integrado de Capacitação Empreendedora

Escola Politécnica da USP

Pró-reitoria de Pesquisa da USP

Rede USP de Novos Negócios

Serviço Brasileiro de Apoio às Micro e Pequenas

Empresas

Universidade Estadual de Campinas

Universidade Federal de Itajubá

Universidade de São Paulo 


\section{LISTA DE TABELAS}

Tabela 1 - Diferentes abordagens entre grassroots e institucional .................................32

Tabela 2 - Matriz de exploração das entrevistas realizadas............................................ 40

Tabela 3 - Matriz de Amarração da Dissertação .................................................................. 41

Tabela 4 - Organização das aulas e objetivos do curso online ..........................................57

Tabela 5 - Tabulação de dados da escala Likert ........................................................... 78

Tabela 6 - Distribuição das notas da escala Likert........................................................... 79

Tabela 7 - Relação entre base teórica e dados levantados ............................................... 83

Tabela 8 - Atividades e potenciais métricas quantitativas........................................... 84

Tabela 9 - Características encontradas nos estágios de maturidade de organizações

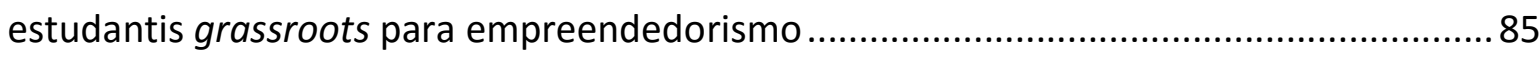

Tabela 10 - Estrutura do Modelo de Maturidade NACUE adaptada: Pilares x Estágios de Maturidade

Tabela 11 - Tensão entre suporte e risco na ação institucional para com o desenvolvimento do modelo grassroots 


\section{LISTA DE ILUSTRAÇÕES}

Ilustração 1 - Organização dos capítulos da dissertação................................................... 14

Ilustração 2 - Modelo de Ecossistemas de Empreendedorismo .........................................17

Ilustração 3 - Espiral positivo de transbordamentos no empreendedorismo ...................... 19

Ilustração 4 - Ecossistema de empreendedorismo em universidades de pesquisa............. 24

Ilustração 5 - Oposição entre abordagem bottom-up dos grassroots e top-down

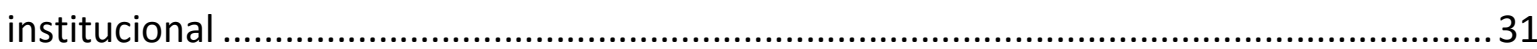




\section{INTRODUÇÃO}

\subsection{Contexto}

No contexto socioeconômico global, vive-se um momento de reinvenção de mercados e busca por soluções inovadoras frente às crises econômicas, à escassez de recursos e ao desafio da competitividade em nível global. Para isso, governos de nações diversas estão buscando se mobilizar para revolucionar seus países por meio do empreendedorismo (ISENBERG, 2010). Um dos mais emblemáticos casos de desenvolvimento econômico por meio do empreendedorismo durante crises é o de Israel, país que tem concentrado seus esforços na criação de novos negócios e investimento em inovação. Os resultados, mesmo perante tensões regionais de variadas naturezas, são apontados por Senor e Singer (2011) no livro 'Nação Empreendedora' ao explorar o impacto positivo do empreendedorismo mesmo em períodos de guerra - afirmando, inclusive, que "a participação do país no mercado de capitais de risco não caiu - de fato, ela mais que dobrou" (SENOR E SINGER, 2011). No desenvolvimento de ecossistemas um pilar de destaque é a Ciência e a Tecnologia a partir de suas instituições de ensino, com ênfase no Ensino Superior. Israel mostra-se como caso emblemático nos esforços de grandes líderes da nação, podendo-se destacar a figura de Shimon Peres - que em sua atuação sempre reforçou o papel da Ciência como agente transformador da região (TEPPER, 2013; PERES, 2016) em seus investimentos em educação básica, centros de pesquisa estrangeiros e, especialmente, nas renomadas Universidades do país. Os esforços no desenvolvimento de uma população altamente educada em pensamento científico, inclusive com um programa de ensino básico envolvendo 5 matemáticas, é pauta dos discursos do líder político em seus mais de 50 anos de carreira que transformou o país de uma economia essencialmente agrícola para uma economia de alta tecnologia (UDASIN, 2015).

O Brasil também tem se posicionado quanto ao seu compromisso com a criação de novos negócios, sendo apontado pelo Public Forum Institute, como um país com grande potencial econômico (BOOKER, 2013). A posição do Instituto é reforçada pelos números do Global Entrepreneurship Monitor (SINGER; AMORÓS; ARREOLA, 2015), que apontam o país como a maior taxa de empreendedorismo entre os BRICs (Brasil, Rússia, Índia e China) e constantemente se destacando por seus números. Além do Brasil, tal 
tendência vem sendo percebida em outros países, que passaram a investir em desenvolvimento pela da criação de novos negócios, como, por exemplo, o caso dos países Ruanda, Chile e Islândia (ISENBERG, 2010). Com a busca para o fomento a iniciativas empreendedoras nos países, surgiu a percepção de que se faz necessário um conjunto de iniciativas coordenadas, articulando diversos participantes do universo relacionado a empreendedorismo - os chamados ecossistemas de empreendedorismo (NADGRODKIEWICZ, 2014).

Recentemente, o Governo Federal do Brasil também se destacou por esforços nesse sentido, ao explorar o desenvolvimento de startups de tecnologia da informação por meio do programa 'Start-Up Brasil', inspirado na iniciativa pioneira Start-Up Chile, criada em 2010. $\mathrm{Na}$ ocasião do lançamento, foram elucidadas algumas questões relevantes acerca do programa, como "fortalecer o ecossistema de startups no país para aumentar a competitividade do Brasil e estimular o desenvolvimento econômico" (QUIANO, 2013) sustentando-se em cinco pilares: (i) desenvolvimento econômico e social; (ii) posicionamento internacional; (iii) inovação e empreendedorismo; (iv) produção científica, tecnológica e de inovação; (v) competitividade.

Daniel Isenberg, diretor executivo da Babson College, instituição de ensino reconhecida por seu engajamento com empreendedorismo, construiu em seu projeto de desenvolvimento de um modelo de ecossistema de empreendedorismo que tem como objetivo organizar os participantes de um ecossistema, elencando-os em seis grandes elementos: mercado; políticas públicas; estrutura financeira; padrões culturais; mecanismos de suporte; e capital humano (ISENBERG, 2011).

O fator capital humano apontado no modelo de Isenberg é reforçado em uma análise apresentada à Bloomberg sobre a perspectiva referente ao Brasil e seus investimentos. Segundo a mesma, o ecossistema brasileiro é um dos que é mais analisado como potencial, porém há uma grande escassez de talentos capacitados para atuarem em negócios de alta tecnologia - fator apontado como o maior gargalo do País para uma grande transformação (LEVIN, 2015).

Nesse contexto de desenvolvimento, poderiam as universidades desempenhar um papel efetivo no sentido de (i) estimular potenciais empreendedores na construção de seus 
próprios negócios, (ii) formar massa de trabalho altamente qualificada e (iii) gerar conhecimento e tecnologia aos mercados ávidos por novas soluções e potencialidades para inovação? Apesar desse papel, alguns estudos apontam que o Brasil ainda se encontra insuficiente quanto à capacidade de oferecer o suporte necessário por meio de suas universidades. Segundo a pesquisa "Empreendedorismo nas Universidades Brasileiras", em 2012 eram baixos os números dedicados à formação de empreendedores por parte das Universidades Brasileiras (ENDEAVOR, 2012). A deficiência na formação de empreendedores ainda era maximizada por outro ponto no espectro da pesquisa: somente $38,1 \%$ dos universitários que pensam em abrir seu negócio afirmam se dedicar ao ato de se capacitar para empreender.

A necessidade de a universidade desempenhar um papel mais efetivo em ecossistemas de empreendedorismo tornou-se pauta em estudos acadêmicos, como o de Woollard, Zhang e Jones (2007), trazendo com estes o conceito de terceira missão ${ }^{1}$ ("third mission"). O conceito e interesse também ganham força nas universidades do Brasil, gerando esforços tanto institucionais - como medidas estratégicas por parte do corpo diretivo das instituições -, quanto movimentos autônomos, liderados por estudantes, professores e pesquisadores engajados com a causa, sendo este último aspecto central do presente estudo - o fenômeno dos chamados movimentos grassroots. Tais movimentos se caracterizam por serem de orientação "de baixo para cima", ou seja, autônomos, não institucionalizados, de gênese informal e com agendas próprias e independentes. Ao passo que se desenvolvem, passam a possuir influência e apoio por parte de níveis hierárquicos mais altos de instituições, gerando impactos estratégicos e transformação no direcionamento das universidades. Tais movimentos ganharam destaque nos processos de mudança relativos à orientação das universidades para uma terceira missão, temática presente em estudos da sociologia do ensino superior (CLARK, 1973), tendo como autores advogando em causa Etzkowitz (2013) e Clark (2004). Alinhando-se à proposta da presente dissertação, dá-se destaque no contexto dos grassroots universitários para empreendedorismo uma associação de organizações do Reino Unido, a NACUE (National Consortium of University

1 Entende-se como terceira missão na universidade "a promoção do desenvolvimento socioeconômico a partir do estímulo à aplicação prática do conhecimento gerado neste ambiente" (MARTINS, 2014, p. 5). Deste modo, cabe à primeira missão ensinar, à segunda, pesquisar, e à terceira gerar transbordamentos do conhecimento - gerando inovações, novos negócios e educação continuada, bem como melhores relações com elementos socioculturais, com o poder público e com o mercado de uma maneira geral (LAREDO, 2007). 
Entrepreneurs), que além do destaque no ambiente universitário, ganhou força e apoio governamental por parte do Governo Britânico, desempenhando diversos esforços no desenvolvimento de organizações grassroots na nação - sendo um destes esforços a criação do Modelo de Universidade utilizado (NACUE, 2012).

\subsection{Relato de experiência}

O relato de experiência que direciona a presente dissertação se pauta em um fenômeno ligado ao nascimento e crescimento de dezenas de empresas de destaque (99taxis, Nubank, Worldpackers, Kekanto, Ifood, Tecmudas e Lean Survey entre outras), fundadas por alunos e ex-alunos da Universidade de São Paulo (USP). Tal fenômeno carrega consigo relação direta com a coordenação de esforços por parte do Núcleo de Empreendedorismo da USP (NEU), organização autônoma e nascida a partir de impulsos individuais de alunos, pesquisadores e professores, em parceria com diversos outros agentes.

O NEU surge em 2012, como um movimento (que veio a se tornar uma organização formal, com sede física dentro da USP e CNPJ próprio) composto por alunos da graduação e pós-graduação direcionada à missão de fomentar uma cultura de empreendedorismo na Universidade de São Paulo, contando com parceiros em diversas organizações, tais como:

- Unidades de ensino da USP - Instituto de Matemática e Estatística (IME/USP), Faculdade de Economia, Administração e Contabilidade (FEA/USP) e Escola Politécnica da USP (Poli/USP);

- Braços Institucionais - Associação da Escola Politécnica (AEP), Agência USP de Inovação (Auspin), Pró-Reitoria de Pesquisa (PRP/USP).

- Laboratórios e núcleos de pesquisa - Núcleo de Política e Gestão Tecnológica da USP (PGT/USP), Inovalab da Poli, Centro de Competência em Software Livre do IME/USP (CCSL).

O principal traço da organização se mostra no fato de ser um fenômeno "grassroots", ou seja, possuir crescimento autônomo, vindo das bases e sem interesses ou agendas institucionais definidos externamente. Como resultado desses esforços autônomos baseados nos interesses do corpo de fundação e diretamente ligados aos interesses de empreendedores da USP, o Núcleo de Empreendedorismo da USP pôde presenciar o nascimento de novos negócios em sua rede, a conexão de muitas empresas, o 
amadurecimento de empreendedores, o fortalecimento de equipes via contratação de estagiários da USP, e o direcionamento de startups para processos relevantes de aceleradoras, fomentos governamentais e pontes com fundos de investimento.

As três bases utilizadas pelo NEU no cumprimento de sua missão no ecossistema da USP são: inspiração, capacitação e conexão - partindo sempre da premissa que esse processo desencadeia um movimento cíclico positivo, no qual alunos apoiados tornam-se empreendedores que, por sua vez, apoiam novos alunos no futuro. No final do ano de 2014 e durante o ano de 2015, o Núcleo passou por um momento de consolidação, estabelecendo-se fisicamente no laboratório Inovalab da Escola Politécnica da USP. Neste momento, ganha maior destaque pelos seus casos de sucesso, materializados pela presença em diversos veículos midiáticos (Estado de São Paulo, CBN, Jornal da Globo, Jornal O Politécnico entre outros) devido o representativo papel desempenhado referente ao estímulo do empreendedorismo.

A existência do Núcleo dialoga diretamente com um movimento expressivo - e natural - da Universidade de São Paulo voltando-se para cumprir um papel positivo e ativo no ecossistema de empreendedorismo da cidade de São Paulo, bem como reforça a importância do fenômeno grassroots nesse processo, que também é evidenciado em outras iniciativas dentro da USP, tais como o Inovalab e o Centro de Competência de Software Livre (IME-USP). Em paralelo aos movimentos na USP, desenvolviam-se organizações similares no mundo inteiro, sendo referência para o NEU movimentos que surgiam na Escandinávia (SOCIETY, 2016) e no Reino Unido (PENWARDEN, 2013).

\subsection{Problema de pesquisa}

Como já apontado na contextualização do projeto, é evidente, no momento atual do País, a demanda por maior participação da universidade - especialmente universidades de pesquisa - em ecossistemas de empreendedorismo. Diante dessa demanda e das movimentações para suprir deficiências relativas a esse papel, residem as dificuldades enfrentadas pelas universidades em tal direcionamento de suas ações - que se desmembram na limitação ao enxergar os caminhos a percorrer, bem como na limitação referente aos processos relativos a essa transformação. Os movimentos autônomos de alunos têm se configurado como uma estrutura possível para complementar os esforços da Universidade e até mesmo assumir 
certo protagonismo no direcionamento da mesma para o estímulo ao empreendedorismo regional. Com base nisso, a problemática reside em compreender como desenvolver organizações grassroots que cumpram um papel efetivo no incentivo ao empreendedorismo de maneira sustentável nas universidades.

Vale ressaltar que tal problemática traz consigo uma orientação a produtos de pesquisa de naturezas diferentes, porém complementares: em primeiro lugar, busca identificar modelos já vivenciados que se direciona a resultados descritivos, e, em segundo lugar, anseia por referências e direções que permitam novos avanços no que tem sido realizado dentro das universidades.

\subsection{Questão de pesquisa}

A problemática apresentada traz à tona a seguinte questão: como os movimentos grassroots, liderados por alunos, podem desempenhar um papel efetivo no incentivo ao empreendedorismo em universidades de pesquisa brasileiras?

\subsection{Objetivos do trabalho}

O objetivo principal da pesquisa é propor um marco referencial capaz de nortear esforços por parte de alunos e clarificar o modelo grassroots para auxiliar a decisão de gestores de universidades e outros agentes institucionais que podem catalisar o papel de tais movimentos para empreendedorismo. A composição deste marco dialoga com a orientação dada pela problemática: um elemento descritivo trazendo melhor compreensão sobre o fenômeno e um elemento normativo, sendo este um ferramental para uma análise de maturidade de organizações deste tipo.

Sendo a pesquisa de natureza exploratória e qualitativa, tem-se como objetivos específicos:

(i) Descrever, por meio de um relato com observador participante, as potencialidades e boas práticas de um movimento grassroots para empreendedorismo, sendo o Núcleo de Empreendedorismo da USP o objeto central. 
(ii) Levantar, por meio de levantamento de experiências, percepções acerca do desenvolvimento de movimentos grassroots para empreendedorismo em outras universidades brasileiras.

(iii). Validar e adaptar ao cenário brasileiro, por meio de levantamento de experiências, um Modelo de Maturidade utilizado por movimentos grassroots para empreendedorismo no Reino Unido.

(iv). Organizar o material produzido de modo a oferecer uma estrutura normativa que sirva como base para nortear esforços.

\subsection{Justificativa e contribuições}

O potencial do projeto se justifica pelos já citados impactos econômicos relacionados ao empreendedorismo e pelo potencial relacionado ao papel da Universidade na criação de novos negócios, especialmente em empresas de tecnologia (LEMOS, 2012). Borison (2014) apresenta a universidade como ambiente recorrente de nascimento de empresas de base tecnológica pelo mundo e, desse modo, a relevância do presente projeto aproveita o fenômeno do crescimento do interesse de graduandos e recém-graduados em empreender, bem como no aumento do movimento de startups em ambientes universitários, como aponta Endeavor (2012). Essa demanda, combinada com a percepção de alunos quanto à ausência de iniciativas que deem suporte ao nascimento de seus negócios, aponta para a necessidade de um modelo capaz de direcionar estratégias claras referentes ao incentivo do empreendedorismo no ambiente universitário.

Acredita-se que as contribuições do projeto trarão frutos no sentido de apresentar, fundamentado por bases científicas, um marco referencial claro sobre potenciais papéis a serem assumidos por movimentos grassroots no incentivo a ecossistemas de empreendedorismo.

\subsection{Organização dos capítulos}

Como estrutura para garantir o cumprimento dos objetivos acima citados, o presente estudo se organiza da seguinte maneira: 


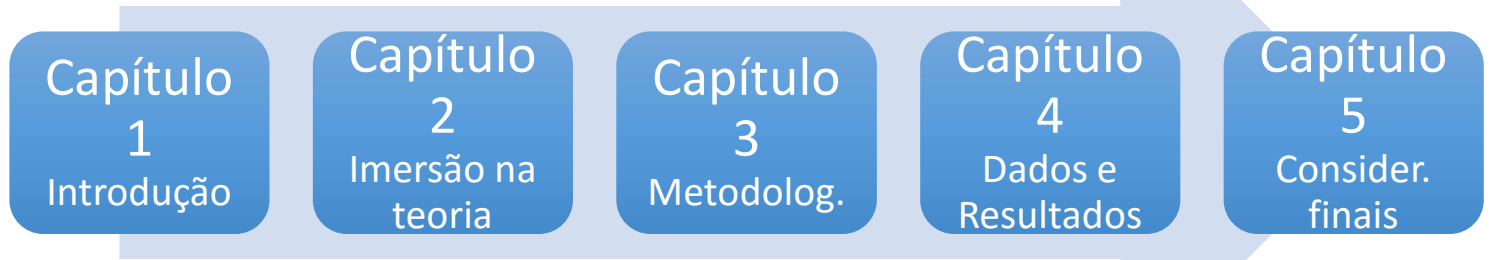

\section{Ilustração 1 - Organização dos capítulos da dissertação}

FONTE: Elaborada pelo autor.

O capítulo inicial centra-se em definir o contexto da situação, tanto em uma análise do cenário global quanto com uma aproximação da experiência vivida pelo autor, elemento característico da dissertação de um mestrado com ênfase na bagagem profissional do pesquisador. O capítulo segundo busca apresentar teorias diretamente relacionadas ao tema proposto para análise, sendo complementado, também, por uma imersão em experiências internacionais relativas ao tema para melhor alicerçar a pesquisa. $\mathrm{O}$ terceiro capítulo apresenta e justifica a escolha do método, vinculado o mesmo com os interesses do estudo presente. No penúltimo capítulo, haverá a apresentação de dados e os resultados encontrados com a pesquisa, sendo diretamente relacionados com a imersão teórica. Por fim, o fechamento da dissertação se dá no capítulo quinto, que contém considerações finais, análises da relação da pesquisa de campo com a teoria, limitações e propostas para estudos futuros esperados. 


\section{IMERSÃO BIBLIOGRÁFICA}

O propósito do embasamento teórico se fundamenta na intenção de guiar o leitor pelos principais estudos já realizados nos temas que envolvem a presente dissertação. Em paralelo, tal arcabouço referencial nutre as reflexões práticas - de modo a confirmá-las, por elas ser complementado e também delinear a estrutura científica do processo científico envolvido. Neste capítulo foram cobertos - (i) empreendedorismo e seu impacto econômico, conceituando o tema e trazendo as defesas de sua relevância; (ii) o conceito de ecossistemas de empreendedorismo, elucidando a base para as reflexões e trazendo modelos visuais; (iii) o papel das universidades em ecossistemas de empreendedorismo, trazendo as principais abordagens de como desempenhar impacto efetivo em um ecossistema e, também, modelos internacionais de universidades relevantes nesse sentido (Stanford, MIT, Technion e Aalto); (iv) a transformação da universidades e os movimentos grassroots para empreendedorismo, que finaliza a imersão dialogando com o objeto de estudo.

\subsection{Empreendedorismo e seu impacto econômico.}

O termo "empreendedorismo", apesar de profundos esforços para uma elucidação conceitual - como os de Gartner (1985) em seu artigo "A conceptual framework for describing the phenomenon of new venture creation" - ainda apresenta diversas, e distintas, etimologias e, principalmente, dúvidas quanto a sua real significância. Para fins de esclarecimento quanto ao referencial utilizado pela pesquisa, definiu-se a compreensão de empreendedorismo apresentada pelo Global Entrepreneurship Monitor (GEM) em seu relatório do ano de 2011 que apresenta o empreendedorismo como um processo que compreende as diferentes fases de desenvolvimento do empreendimento, abrangendo as fases: intenção de iniciar um negócio; efetivação da criação; administração do negócio inicial; empreendimento já estabelecido (ANDREASSI et al, 2011).

A importância do movimento de empreendedorismo caminha com bastante alinhamento ao desenvolvimento econômico. Em conclusão ao seu livro Inovação e Espírito Empreendedor, Drucker (1985) ressalta o papel do empreendedorismo frente à necessidade de revoluções como forma de restauração de diversos contextos, evitando, desta maneira, que os mesmos tornem-se obsoletos. Diversos autores complementam tal tese da relação positiva direta entre empreendedorismo e desenvolvimento econômico, com destaque a 
Schumpeter (1942), Gibb (1996), Dahlstrand (2007), Acs, Desai e Hessels (2008). Em uma cena brasileira, a prosperidade econômica também é ressaltada por Andreassi et al (2011) nas análises do GEM (Global Entrepreneurship Monitor), apresentando o empreendedorismo como fator crítico para desenvolvimento econômico, bem estar social, geração de renda e, inclusive, como solução em períodos de recessão mundial.

A figura do empreendedor como criador de empresas em período universitário passa a ganhar destaque com os movimentos ocorridos no Vale do Silício e na Rota 128, onde a juventude das Universidades de ponta dos Estados Unidos começou a se engajar na construção de novos negócios e levantar empresas de alto impacto. Diversas empresas tiveram suas bases nesses ambientes, como a relação de Stanford com Google e HewlletPackard Co. (HP) e MIT com Qualcomm. Este movimento atuou como um estímulo à percepção de alunos de diversas universidades ao redor do mundo sobre à própria capacidade de criar negócios, gerando um boom de empresas de tecnologia, as chamadas startups, com suas bases em instituições de ensino (BORISON, 2014). Conceitualmente, uma startup é uma fase de uma empresa de base tecnológica na qual se busca encontrar um modelo de negócios sustentável a longo prazo e desenvolver uma estrutura com potencial de tornar-se escalável, ou seja tornar-se capaz de fazer com que a base de clientes/receita cresça de modo notavelmente superior ao crescimento da estrutura de custos e de recursos utilizados (RIES, 2011). Quanto à base tecnologia, essencialmente estão ligadas a tecnologia da informação - seja no core ou em suas subjacências. Segundo Kon et al (2014), de 2004 a 2014 foram mais de 200,000 startups ao redor do mundo.

\subsection{O conceito de ecossistemas de empreendedorismo}

Tem sido tônica de estudos (MCKEON, 2013) a crença de que, para estimular o surgimento de novos negócios, é preciso desenvolver uma gama de iniciativas buscando a promoção da articulação dos diversos participantes do processo de empreender. Nesta linha, Regele e Neck (2012) apresentam o conceito de "ecossistema de empreendedorismo" como um quadro formado por um conjunto de condições que estimulem a atividade empreendedora de alto nível, tais como: acesso a financiamento; existência de programas governamentais de empreendedorismo; ensino de empreendedorismo; políticas que contribuam para a transferência de P\&D; infraestrutura legal e comercial; e facilidade regulatória para a criação de novos empreendimentos. Um dos mais relevantes defensores deste paradigma é o já citado Daniel Isenberg, Ph.D., Diretor Executivo da Babson College, figura presente 
entre as principais universidades voltadas para empreendedorismo do mundo, que desenvolveu o programa 'The Babson Entrepreneurship Ecosystem Project' (ISENBERG, 2011).

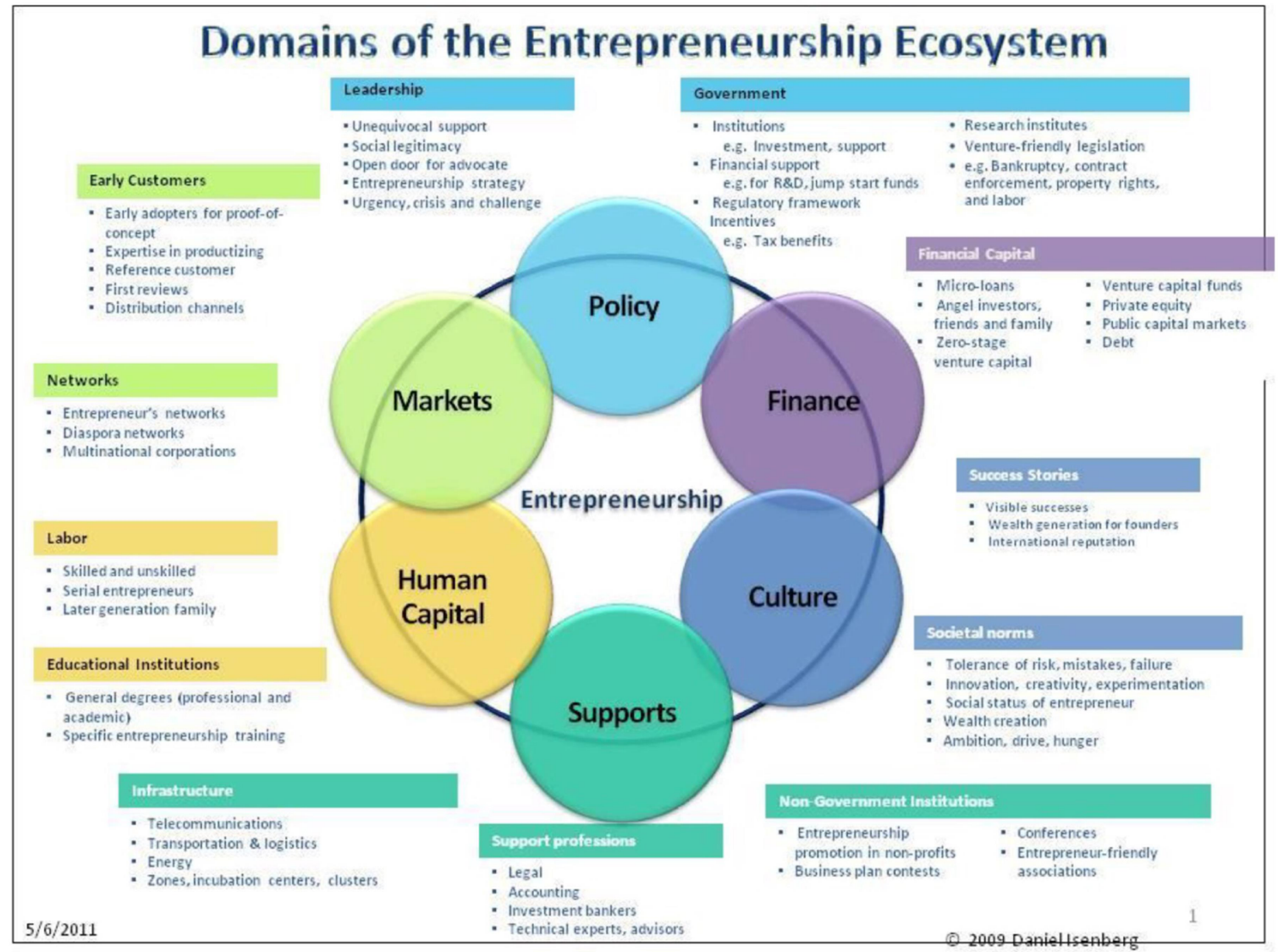

Ilustração 2 - Modelo de Ecossistemas de Empreendedorismo

FONTE: Isenberg (2011)

Buscando explorar ecossistemas de startups de Israel, Kon et al (2014) identificou elementos característicos do ecossistema de empreendedorismo em Israel, encontrando a seguinte disposição, mais centrada em questões culturais que podem impactar positivamente em tais comunidades: (i) a presença de uma Universidade de ponta (ex: Technion Institute of Technology), (ii) uma mistura cultural de empreendedores, investidores e acadêmicos experientes e altamente talentosos, (iii) bem-estar e qualidade de vida com escritórios casuais (maior liberdade em horários, dress code e arquitetura aberta), cultura de trabalho saudável e desdém por modelos de comunicação hierárquicos, (iv) pessoas de diversas partes do mundo e atos que encorajem imigrantes talentosos a se mudarem para centros urbanos, (v) risco e falha sendo tratados como parte da jornada 
empreendedora, (vi) empreendedores autênticos com paixão para fazer a diferença no mundo, (vii) uma indústria de patentes bem estabelecida, (viii) pessoas autenticamente apaixonadas guiadas por ideias, corajosas na tomada de risco, confiáveis e resilientes, (ix) nenhuma ideia sendo considerada louca, (x) a indústria de Venture Capital em um ciclo virtuoso onde empreendedores usam seus ganhos para investir em novas startups, e (xi) cultura de network com ideias livremente sendo trocadas entre os atores.

Para Feld (2012), um dos responsáveis pela construção do ecossistema de Boulder, Colorado, a articulação dos principais atores em um ecossistema é fundamental, porém, faz-se necessário que o movimento seja liderado fundamentalmente por empreendedores, visto que os mesmos apresentam compreensão e compromisso mais profundo em relação às necessidades e realidades locais. Além do caráter de ser liderado por empreendedores, o autor defende que o bom estabelecimento de um ecossistema de empreendedorismo só se dá quando tais líderes assumem compromissos de longo prazo com a comunidade, característica que se desdobra em fortalecimento de rede de contatos, de atenção ao movimento e de conhecimento adquirido/transferido. Alguns outros fatores, como uma cultura de abertura para diversos atores são apresentados em seu livro. Isenberg (2010) também propõe uma estrutura em forma de fluxo para demonstrar o que pode ser gerado ao desenvolver um ecossistema de empreendedorismo. Inicialmente, são oferecidas capacitação e inspiração, com o objetivo de formar competências básicas e uma mentalidade de empreendedor; após essa etapa, é fornecido capital e experiência para estimular os empreendedores a abrirem seu próprio negócio e adquirirem crescimento. Com isso, vem a realização de sucesso e riqueza por meio do negócio, e, segundo o autor, há um retorno natural em forma de inspiração, capital e experiência para a comunidade de futuros empreendedores. O espiral positivo - movimento no qual bons resultados atraem novas atividades que colaboram com novos bons resultados - de Isenberg (2010) trata o espiral positivo dos ecossistemas de empreendedorismo da seguinte maneira: 


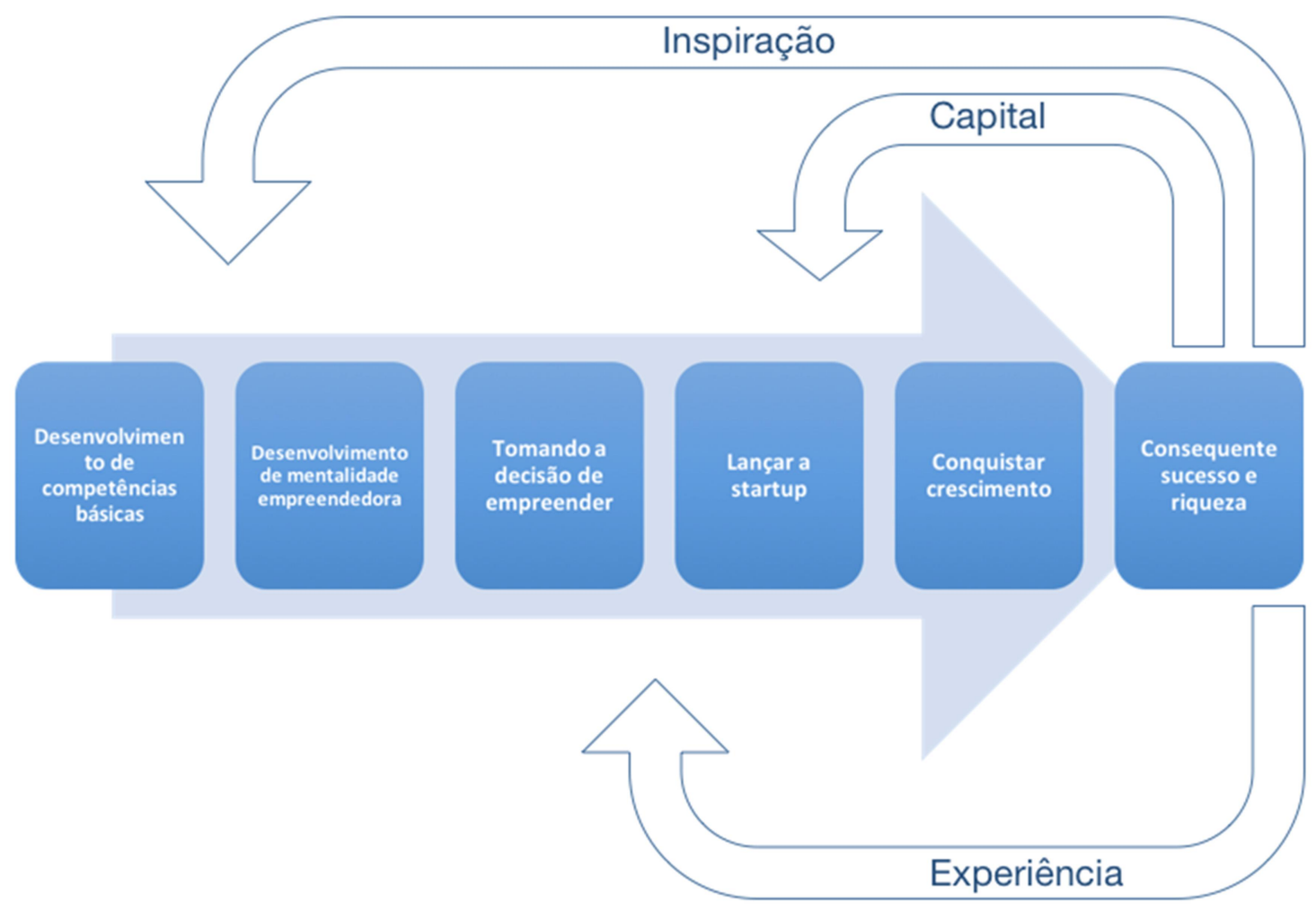

Ilustração 3 - Espiral positivo de transbordamentos no empreendedorismo

FONTE: Adaptado de Isenberg (2011)

Isenberg (2011) reforça esse conceito com uma alusão a transbordamentos, usando o conceito de spillovers:

\begin{abstract}
"Spillovers são feedbacks positivos, e todos os engenheiros sabem que um sistema com feedbacks positivos chegam em um ponto no qual isso se torna relativamente autônomo e automático. $\mathrm{Na}$ verdade, se você observar regiões que se tornaram extraordinariamente empreendedoras, tais como Taiwan, Israel, Islândia, bem como regiões específicas como Boston e Vale do Silício, (...), você perceberá o empreendedorismo ganhando tração e decolando. As pessoas começam a falar sobre isso, e se torna socialmente aceitável, as instituições começam a se desenvolver, e o governo passa a reconhecer isso como algo positivo e a ouvir os novos empreendedores influentes e suas iniciativas. $O$ ecossistema se fortalece, o que gera mais empreendedores, que fortalece mais o ecossistema. Sucesso gera sucesso." (ISENBERG, 2011, p.9. Tradução do autor.)
\end{abstract}

\title{
2.3 O papel da universidade em ecossistemas de empreendedorismo
}

Neste tópico, pretende-se imergir no papel desempenhado pelas universidades em ecossistemas de empreendedorismo no sentido de desempenhar um papel efetivo estimulando a criação de empresas. O tópico é dividido entre (a) as referências de estudos e 
(b) modelos internacionais posicionados como referência no papel efetivo de desenvolvimento do ecossistema em que se insere.

\subsubsection{Estudos relativos ao papel da universidade como efetiva no incentivo ao empreendedorismo}

Segundo Martins (2014), o processo de evolução do papel das universidades começa em meados do séc. XIX, momento em que se amplia sua missão principal para o campo da pesquisa - não mais somente focando em ensino. Com o desenvolvimento da pesquisa e da geração de conhecimento, desperta-se a atenção dos agentes do setor produtivo, há maior participação do capital privado no ambiente acadêmico e ocorre maior atração de investimentos. Na segunda metade do século XX, ocorre a incorporação da inovação tecnológica à missão da universidade. A partir deste marco, sua importância para a sociedade cresce significativamente devido às relações com o desenvolvimento econômico e social, tornando-se elemento chave na transferência de tecnologia e formação de capital humano. Para a autora, a intensificação da relação universidade-empresa ocorre por quatro fatores interligados - (i) o desenvolvimento de novas plataformas tecnológicas; (ii) o aumento na produção científica ligada a diversos aspectos da indústria; (iii) demanda por novas estruturas de financiamento acadêmico; (iv) a intensificação de políticas governamentais atentas à transferência de tecnologia da universidade. Dada a evolução do papel das universidades, percebe-se um aumento das interfaces e o fortalecimento da influência desempenhada pela universidade no desenvolvimento econômico. Destaca-se também da teoria o caráter muitas vezes subversivo por parte dos movimentos de empreendedorismo dentro da universidade - sendo muitas vezes uma atividade vista de maneira conflituosa com tais propósitos iniciais das instituições de ensino superior. Ainda hoje, a aplicação da pesquisa científica no meio acadêmico enfrenta tensões e visões contrárias a tal atividade, com a percepção de que a comercialização da pesquisa atua em detrimento do ethos de desenvolvimento da pesquisa pura (NYMAN, 2015).

O destaque dado para o papel da educação na construção de um ecossistema de empreendedorismo já tem raízes em décadas anteriores. De acordo com Katz (2003), um dos primeiros cursos de empreendedorismo foi ofertado pela Harvard Business School, em 1947, em uma turma de MBA de 188 alunos - e em 1994 mais de 120.000 estudantes faziam aulas de empreendedorismo ou pequenos negócios. Frente a este aspecto, diversas medidas têm historicamente sido tomadas por parte de gestores públicos no sentido de estimular a transferência de tecnologia e a atuação de Universidades de maneira mais ativa nos ecossistemas. Kon et al (2014) destaca, em um exemplo dentre diversos pelo mundo, o Bayh-Dole Act, em 1980, nos Estados Unidos da América, como um elemento legal que melhor organizava estruturas legais e burocráticas para transferência de tecnologias 
surgidas em universidades públicas e centros de pesquisa a serem aplicadas em indústrias de alta tecnologia, gerando um aumento considerável na produção de produtos tecnológicos e negócios de sucesso a partir de avanços científicos. Lemos (2012) apresenta o caso de Stanford como um processo de "co-evolução", no qual os componentes relevantes de um ecossistema evoluem de maneira interativa, porém espontânea, com o mercado, com as startups nascidas, com as tecnologias etc. Tal abordagem é complementada por Etzkowitz (2003):

\footnotetext{
"Stanford University and Silicon Valley developed as a virtual joint venture. The metamorphosis of the region and the university was a cooperative and collaborative effort in which the evolution of the Valley was inextricably interwined with the transformation of the university. Stanford played a significant role in creating the vision and implementing rhe strategy that produced the world's leading complex of high technology firms. The rise of these firms in turn fed back into the growth of university by providing it with a pathway for its students, a market for its technologies and partners for building new research collaborations. By assisting the economic development of its region, Stanford transformed itself into a leading research university." (ETZKOWITZ, 2003, p. 102)
}

Para Glaeser e Kerr (2010), os governos atuais possuem o interesse na construção de ecossistemas por meio de uma cidade empreendedora, e este modelo requer quatro elementos-chave: (i) uma infraestrutura que permita uma fácil entrada de novas empresas no mercado; (ii) um alto percentual da população com formação educacional superior; (iii) tomadores de medidas públicas locais e estatais focados em desenvolver uma região que ofereça pessoas competentes e empreendedoras; e (iv) robustas relações entre empreendedorismo e instituições voltadas para educação.

Plonski e Carrer (2009), apresentam três espectros de atuação que a universidade pode assumir em relação ao empreendedorismo - o primeiro sendo a sala de aula; o segundo configurado pelos laboratórios; e o terceiro sendo as incubadoras, combinando conhecimentos de maneira a gerar valor percebido pela sociedade através da incorporação em bens e serviços. A universidade traz para si, portanto, um papel fundamental no suporte à formação de novos empreendimentos, seja com sua pesquisa acadêmica, seja com iniciativas de apoio ao desenvolvimento e comercialização de tecnologias, como 
incubadoras de negócios e núcleos de empreendedorismo. Diversos autores, dos quais se destacam Etzkowitz et al (2000), Bessant e Tidd (2009), Chwolka e Raith (2012), Wright et al (2009), Clarysse, Bruneel e Wright (2011) e Kasabov (2013), apontam para a importância do papel da universidade e da educação formal como agentes de estímulo ao empreendedorismo. As escolas de administração, pontuadas como integrantes do processo de ensino de ferramentas e mecanismos de gestão e criação de novos negócios, são tratadas como elementares (KIRBY, 2002).

McKeon (2013) afirma que a universidade também pode exercer forte impacto no desenvolvimento comunitário local, exemplificando com o caso de Oklahoma, na cidade de Tulsa. Segundo o autor, o desenvolvimento regional se deu pela Tulsa Community College desempenhando atividades de suporte local, tais como:

(a) Tulsa Spirit Award: Uma competição organizada em 2007 para inspirar e aumentar o engajamento em empreendedorismo na cidade. Em 2012, a Universidade Tulsa Community College passou a patrocinar a competição. Desde 2007, os finalistas da competição já adicionaram mais de 8 milhões de dólares em salários anuais da cidade, gerando um salário médio de aproximadamente 45 mil dólares.

(b) Launch Your Entrepreneurial Journey: Um programa não-convencional desenvolvido pela Universidade em 2010 para estimular empreendedores locais a lançarem suas ideias no mercado. O programa tem um modelo centrado em coachs que acompanham passo-a-passo o começo de negócios. No primeiro ano de funcionamento, o programa adicionou aproximadamente 1,3 milhão de dólares em salários anuais na cidade, com 29 novos empregos criados por 7 novas empresas.

Outro papel que pode ser desempenhado pela universidade, segundo Feld (2012), está relacionado a utilizar os recursos físicos e humanos para catalisar ecossistemas de empreendedorismo. Por ter excelentes espaços para trabalhar, auditórios e grandes locais para conferências em sua estrutura física e alunos interessados em empreendedorismo, há um potencial para realização de atividades e conferências - além de ser um celeiro de talentos para atuação em empresas nascentes. Sobre a característica de ser um celeiro de talentos, McKeon (2013) destaca o papel da universidade em reconhecer empreendedores potenciais. Identificar esse perfil disposto a realizar grandes mudanças é o primeiro passo 
de um desafio maior - o de, após reconhecer, encontrar os melhores métodos para instruir e equipar tais empreendedores com conhecimento e ferramentas necessárias para que eles sejam bem-sucedidos em seus negócios. Um mecanismo que tem ganhado destaque na instrução de empreendedores é a aprendizagem experiencial, na qual os alunos são capacitados a partir do engajamento prático com projetos reais e aprofundam seus conhecimentos por meio de vivências e dinâmicas próximas à realidade de um empreendedor (KRAKAUER, 2014).

Compilando o desdobramento teórico sobre possíveis papéis a serem desempenhados por universidades - especialmente as que têm boa parte dos esforços voltados à pesquisa científica - visando uma efetiva atuação no desenvolvimento de ecossistemas de empreendedorismo, pode-se pontuar que tais papéis são: (i) desenvolvimento tecnológico a partir de pesquisas científicas; (ii) capacitação gerencial; (iii) formação de mão-de-obra qualificada para atuar em empresas nascentes; (iv) capacitação em empreendedorismo; (v) influencia na cultura local de empreendedorismo; (vi) oferta de infraestrutura para eventos e atividades que tornem o ecossistema mais vibrante; (vii) suporte à comunidade local; (viii) interface entre empreendedores e instituições de pesquisa, de fomento e com infraestrutura laboratorial; (ix) transbordamento intelectual para o ecossistema a partir de conhecimento acadêmico produzido. Lemos (2012) organizou de maneira visual um marco referencial a maneira como os agentes de uma Universidade de pesquisa (Universidade Estadual de Campinas - UNICAMP) podem se organizar sob um ponto de vista de ecossistemas: 


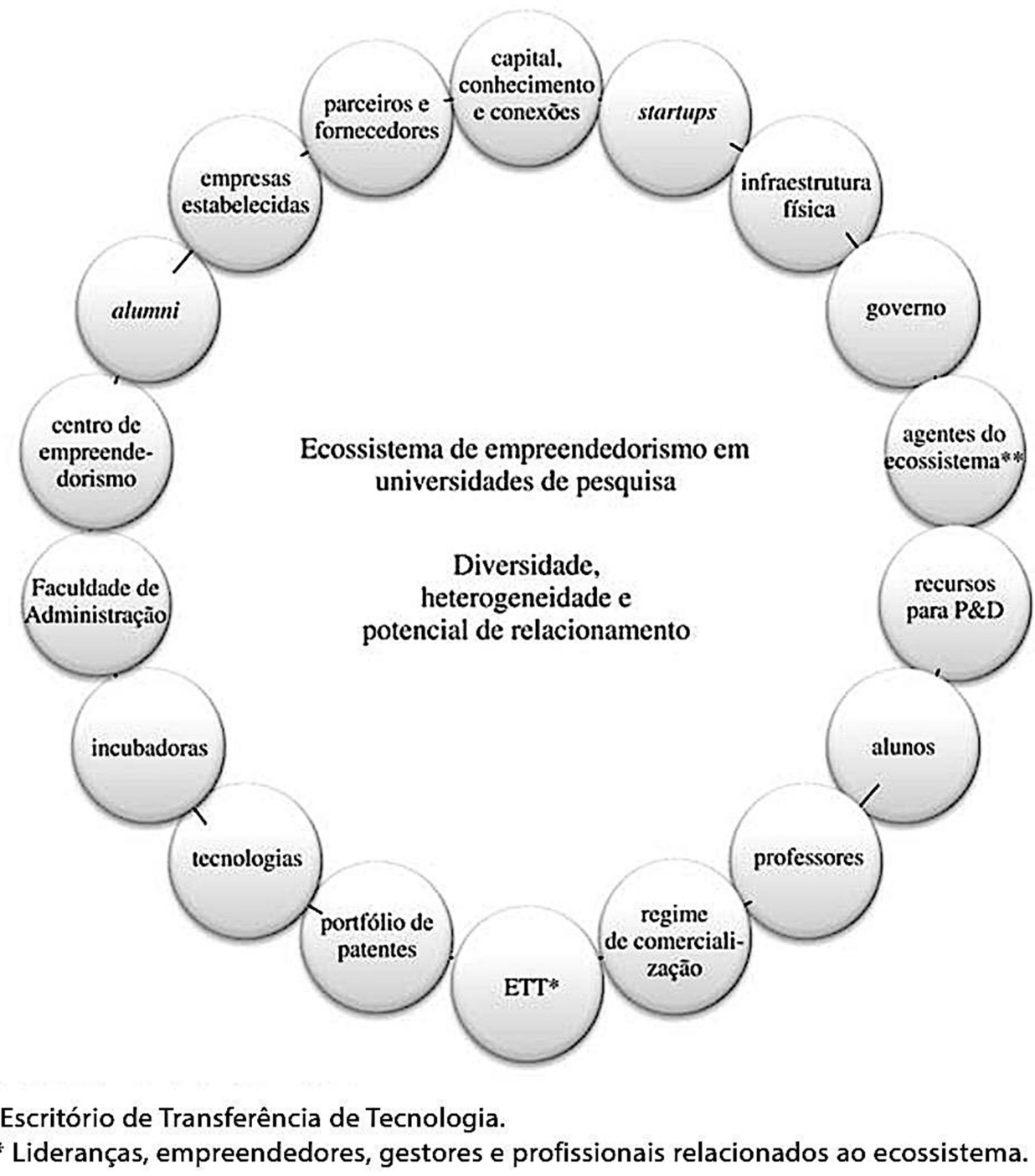

Ilustração 4 - Ecossistema de empreendedorismo em universidades de pesquisa

FONTE: Lemos (2012)

\subsubsection{Modelos internacionais de universidades e ecossistemas de empreendedorismo}

Para fins de enriquecimento do presente trabalho, foram selecionadas quatro experiências de universidades internacionais que se destacam por seus esforços em promover ativamente o empreendedorismo e, deste modo, colaborar com o ecossistema no qual estão inseridas. Foram escolhidas as instituições Stanford University, Massachusetts Institute of Technology (MIT), Israel Institute of Technology Technion e Aalto University, sendo a seleção determinada por três critérios: (i) avaliações de atuação pró-empreendedorismo das mesmas - utilizando o ranking da Forbes (CHEN, 2014), o estudo MIT \& Skoltech 
(GRAHAM, 2014) e o ranking da Entrepreneur (KLICH, 2014); (ii) grau de desenvolvimento dos ecossistemas nos quais elas se inserem, com base em justificativas a serem apresentadas ao longo deste capítulo; (iii) alinhamento com o contexto do presente estudo. As quatro instituições são consideradas como parte do "emergin leaders group" do estudo "Creating university-based entrepreneurial ecosystems - evidence from emerging world leaders" de Graham (2014), fato que as caracteriza dentro da faixa das mais proeminentes universidades em termos de estímulo e desenvolvimento de ecossistemas em seu entorno.

(a) Universidade de Stanford, Estados Unidos: A Universidade de Stanford se destaca naturalmente pela localização onde se encontra: o Vale do Silício. A região se é mundialmente reconhecida pela alta concentração de empresas de tecnologia líderes em seu mercado (Google, Hewlett-Packard Co., Apple entre outras), seu ecossistema vibrante quanto ao surgimento de novas startups e a sua intensa atividade de newtorking entre todas as comunidades ali inseridas (SAXENIAN, 1991). Frente a isso, uma estratégica movimentação por parte da universidade foi fundamental para cumprir o papel de estimular o empreendedorismo no ambiente em que se inseria: conhecida como Modelo Terman. Segundo Etzkowitz (2011), tal modelo nasce dos esforços de um dos líderes acadêmicos da universidade, Fred Terman, Reitor de Engenharia, em estimular a colaboração entre universidade, sociedade e mercado - utilizando estratégias como (i) fortalecimento de escritórios de transferência de tecnologia; (ii) modelos de remuneração acadêmica que fomentavam a busca por aportes privados para projetos de pesquisa; (iii) incentivos para atração de empresas de tecnologia aos arredores do campus; (iv) projetos de associação e cooperação com atividades industriais. Para Etzkowitz (2013), as ações de Terman, que hoje é reconhecido como "o pai do Vale do Silício", foram responsáveis para configurar o formato dos atuais parques tecnológicos e se estruturavam na organização de recursos centrados em uma colaboração entre Governo, Universidade e Indústria, conceito conhecido por Hélice Tripla. As mudanças fortaleceram competências empreendedoras na esfera acadêmica (LEMOS, 2012), atuando diretamente na formação de professores, alunos e pesquisadores que vieram a se tornar empreendedores no Vale do Silício, como aponta o estudo How Silicon Valley became Silicon Valley (MORRIS e PENIDO, 2014), e que desempenharam um 
importante papel na história do desenvolvimento do ecossistema e da cultura de alto risco e empreendedorismo de Stanford (FU e HSIA, 2015).

(b) Instituto de Tecnologia de Massachusetts (MIT), Estados Unidos: O ecossistema de Boston organiza não só um dos principais institutos de tecnologia do mundo, o MIT, mas também a Universidade de Harvard, a Universidade de Boston e outras renomadas. Tal concentração em produção científica e tecnológica em torno da Rota 128 originou os atuais clusters da região, tais como biotecnologia, energia, tecnologias veiculares entre outros. A riqueza deste ecossistema em torno do rio Charles tem influencias trazidas desde os tempos de Segunda Guerra Mundial, nos quais as produções envolvendo a bomba atômica, mísseis guiados, defesa baseada em computação e tecnologias avançadas possuíam bastante relação com a região e com o desenvolvimento científico de suas universidades (ROBERTS e EESLEY, 2009). Apesar da atenção dada aos grandes esforços institucionais destinados à missão do MIT ("mens et manus" - mente e mãos trabalhando juntas) de voltar a produção científica à geração de impacto prático no desenvolvimento de tecnologias, uma das principais características da instituição, segundo Roberts e Eesley (2009), é a autonomia e a riqueza na capilaridade de seus movimentos pró-empreendedorismo. Um famoso caso que materializa tal característica é o de Stark Draper, cujo nome hoje é vinculado à mais alta premiação de engenharia dos EUA (Estados Unidos da América), o Draper Prize. Seu laboratório, autônomo e de pequeno tamanho (com altas taxas de rotatividade e baixos incentivos para permanência a longo prazo), se concentrava em, segundo o professor, ser um ambiente onde jovens engenheiros aprendiam e, depois, poderiam ir para outros lugares para ser bem sucedidos. Tal laboratório gerou um relevante número de spin-offs e seus resultados influenciaram a gestão do MIT a estimular outros pequenos e autônomos movimentos laboratoriais. Além do estudo de Rober e Esley (2009), Tornatzky e Rideout (2014) destacam outras iniciativas capilarizadas fazem com que o Instituto seja tão vibrante no trabalho com empreendedorismo - tais como os movimentos de alumni, a atuação do MIT Entrepreneurship Center (ofertando cursos livres, serviços de mentoria, competições de plano de negócios como a MIT $\$ 100 \mathrm{~K}$, disciplinas para acadêmicos, projetos de times multidisciplinares entres outros) e os clubes de empreendedorismo (Biopharma Business Club; Energy Club; Mobile 
Media Club; Nanotech Club entre outros.), todos característicos por serem autônomos e gerando, deste modo, um impacto regional onde se inserem, fato que coloca o MIT entre as principais universidades do mundo na criação de novos negócios.

(c) Technion Instituto de Tecnologia, Israel: Israel traz em sua história elementos relacionados à guerra, à cultura de sobrevivência em meio a grandes perseguições e a grandes redes de relacionamento conhecidas como "diáspora networks", características das grandes migrações dos povos judeus. Segundo Senor e Singer (2011), os movimentos migratórios fortaleceram o ecossistema israelense de duas maneiras: (i) oriundos da antiga união soviética, um grande volume de engenheiros ajudou a compor as bases intelectuais do país; (ii) conexão com redes empresariais e de investidores em um nível global. Quanto ao histórico regional no envolvimento com conflitos armados, tem-se algumas consequências, tais como um intenso investimento em alta tecnologia, maior capacidade de adaptação habilidade no gerenciamento de riscos e, por último e mais específico ao exército e povo israelense, autonomia em decisões estratégicas, independente da patente militar, centrando-se sempre na excelência, traço característico da cultura conhecido como chutzpah - um misto de insolência com ousadia. Os componentes acima citados, ligados a decisões estratégicas em políticas públicas e lideranças empresariais notáveis, compuseram a chamada "Nação Empreendedora", que hoje possui a maior densidade de startups por número de habitantes no mundo. Segundo Haan e Golany (2011), o papel de Technion em Israel se fortaleceu após a guerra da independência do país, em 1948, com algumas decisões por parte do então primeiro ministro, David Ben-Gurion, que desenhou para este Instituto de Tecnologia uma atuação nos padrões do MIT em sua prioridade máxima dada à ciência e tecnologia de seu governo. A partir deste momento o governo israelense passa a incentivar - utilizando-se de recursos e modelos de cooperação - a atuação conjunta de universidade e indústria, incentivando especialmente o surgimento de spin offs e transferências de tecnologia. Assim como no MIT, ainda há a promoção e incentivo ao empreendedorismo via créditos em disciplinas de criação de negócios, competições de plano de negócios, um centro de empreendedorismo e um programa de suporte a alumnis empreendedores. Fora os esforços públicos no 
incentivo ao desenvolvimento de atividades pró-empreendedorismo em Technion, a instituição carrega consigo uma forte cultura que reflete os padrões do país em que se insere - a ousadia, a criticidade e o espírito de liderança empreendedora, como aponta a análise do papel de Technion escrita pelo New York Times na matéria “The Technion: Israel's Hard Drive” (HARMAN, 2013) - trazendo depoimentos de renomados empreendedores sobre a instituição:

"'I can say without exaggeration that Israel could not have been built without the Technion,' says Yossi Vardi, who has founded or helped build more than 60 companies in Israel and has five degrees from the Technion. 'There is a Technion graduate behind practically every highway, desalinization plant, new missile technology and start-up company in the country. ", (HARMAN, 2013)

(d) Universidade de Aalto, Finlândia: Sempre encabeçando rankings relacionados ao desenvolvimento humano, econômico e outros, a Finlândia também se destaca nas primeiras posições nos rankings globais de empreendedorismo (GEDI, 2014). O país é considerado o que mais investe em startups de estágio inicial, bem como lidera os esforços em políticas públicas para empreendedorismo e inovação, segundo Ortmans (2012). O ecossistema local conta com uma comunidade vibrante de empreendedores, esforço político para transferência de tecnologia, movimentos de aceleradoras de negócios e um histórico de negócios bem-sucedidos (Nokia, MySQL, Rovio entre outras.) que reflete no aumento do interesse na criação de empresas por parte dos habitantes. A Universidade de Aalto possui diversos esforços institucionais para a criação de novos negócios e transferência de tecnologia avançada para o mercado, como apontado por pelo reitor Matti Pursula (PURSULA, 2010) e pelo chefe do Centro de Empreendedorismo da universidade, Will Cardwell (CARDWELL, 2012) ao desenhar as estratégias centradas em (i) processos de transferência de tecnologia; (ii) fortalecimento das relações com o mercado; (iii) desenvolvimento de uma maior cultura de tomada de risco; (iv) direcionamento centrado em inovação disruptiva; (v) delineamento de modelos de aceleração de novos negócios. Porém, o maior destaque é dado aos recentes fenômenos ligados ao seu processo de evolução e participação em ecossistemas de empreendedorismo: como é o caso do surgimento da Aalto Entrepreneurship Society - AaltoES, uma iniciativa estudantil 
autogerida que tomou proporções transformadoras. Segundo a instituição (SOCIETY, 2016) o movimento começou com a simples organização de eventos (que hoje são mais de 100 por ano), ganhou um prédio próprio, organizaram um programa de aceleração de startups via crowdfunding, se tornaram, em meados de 2010, o termo mais famoso da Finlândia nas redes sociais e hoje atuam diretamente nos principais movimentos do ecossistema de empreendedorismo do país. Outros exemplos da abertura da universidade para fenômenos grassroots são apontados no livro "Managing Reform in Universities: The Dynamics of Culture, Identity and Organisational Change” (STENSAKER, VALIMAA e SARRICO, 2012), apontando um caso do desenvolvimento de um programa de ensino organizado por voluntários que em momento algum foram dissuadidos de suas intenções por parte da alta administração da universidade, gerando um movimento que durou mais de dez anos e envolveu dezenas de pessoas em um trabalho consistente que passou a ganhar apoio de professores e gestores.

\subsection{A transformação da universidade rumo ao empreendedorismo por meio dos movimentos grassroots}

O conceito de inovação grassroots é coberto no estudo "Grassroots Innovation: A Systematic Review of Two Decades of Research" de Hossain (2016), que apresenta estudos apontando para a definição do conceito grassroots como a geração de mudanças por meio de uma rede autônoma de ativistas e organizações que promovem mudanças de baixo para cima (bottom-up) para um desenvolvimento sustentável da comunidade em que estão inseridos. O autor apresenta a variedade de tipos de grassroots, podendo ocorrer em forma de movimentos, cooperativas, grupos informais, entidades sociais ou associações voluntárias. No caso da presente revisão bibliográfica, dar-se-á maior atenção aos movimentos e organizações grassroots ligadas ao contexto de empreendedorismo em universidades.

Para fins de elucidação quanto aos termos, pode-se melhor organizar as abordagens da seguinte maneira:

(a) Fenômeno grassroots: trata de um conceito mais amplo, ligado ao comportamento coletivo percebido em sociedades, instituições e ambientes no sentido de surgimento de movimentos grassroots onde se inserem. É um fenômeno 
de causa espontânea e, em muitos casos, sem conexão entre si, sendo naturais das estruturas sociais em que estão inseridos;

(b) Modelo grassroots: trata do formato no qual uma organização surge e se desenvolve. Está ligado a características estruturais e modelo de evolução grassroots (de baixo para cima, espontâneo, autônomo e afins);

(c) Movimento grassroots: trata da disposição de grupos sociais em se desenvolverem de forma autônoma, espontânea e partindo da base de onde se encontram. Podendo ser menos maduros (iniciativas) ou mais maduros (organizações);

(d) Organização grassroots: estágio de evolução de um corpo grassroots que já possui CNPJ, organograma sólido e estrutura de operações madura.

Considera-se importante apresentar as abordagens relativas aos processos de transformação em universidades no direcionamento para fomentar empreendedorismo e inovação. Com o fortalecimento do conceito de Sociologia das Universidades, recentes estudos (LEHDONVIRTA, 2013; ETZKOWITZ, 2013) apontam para os movimentos autônomos universitários como motores de transformação, sejam eles iniciativas de professores, de alunos, ex-alunos e afins. Lehdonvirta (2013) traz o fenômeno da Helsinki Spring, com destaque ao poder transformacional de movimentos universitários na cultura da sociedade finlandesa como um todo, ao passo que Etzkowitz (2013) traz uma visão da transformação evolutiva de Stanford ao longo do tempo e o papel de organizações lideradas por estudantes na mudança centrada na Universidade. Neste processo de transformação, conhecido como grassroots, há um espontâneo movimento de protagonismo por parte de líderes que não foram institucionalmente eleitos e que são desprovidos de agendas ou interesses ligados necessariamente às políticas da universidade. Cabe ressaltar nesta dissertação a força simbólica do termo protagonista - do grego, agonia tem como significado "luta", sendo o protagonista aquele que luta a favor, ao passo que antagonista se caracteriza por ser aquele que se posiciona contra (CORTELLA, 2015). No caso, os movimentos grassroots se mostram assumindo um protagonismo autônomo na transformação das comunidades em que se inserem.

David Goldberg e Mark Somerville, no livro "A Whole New Engineer: The Coming Revolution in Engineering Education" (GOLDBERG e SOMERVILLE, 2014) reforçam 
este pensamento analisando os processos de transformação de Ollin College e University of Illinois, ambas nos Estados Unidos. Para os autores, a universidade deve, em um nível institucional, conectar esses movimentos autônomos, ajudar sua disseminação e fazer com que esses movimentos - chamados pelos autores de 'bright spots' - ganhem força por meio de incentivos e suporte inequívoco. Para os autores, há a necessidade de repensar a maneira de atacar os problemas - ao invés de 'top-down', a transformação na educação pode ser influenciada de maneira 'bottom-up':

"The usual assumption in most organizations is that change comes from the top - through the usual top-down, hierarchical initiative of the boss - but oftentimes administrators are more experienced at perpetuating the status quo than at changing it. On the other hand, individual faculty members or students at the bottom of the pyramid often know that there is a problem and have good ideas about how to fix or improve it, but their bottom-up initiatives flounder, not because they don't work - they do but because they don't diffuse or spread throughout the organization." (GOLDBERG e SOMERVILLE, 2012)

Podendo a abordagem bottom-up versus top-down ser ilustrada da seguinte maneira:

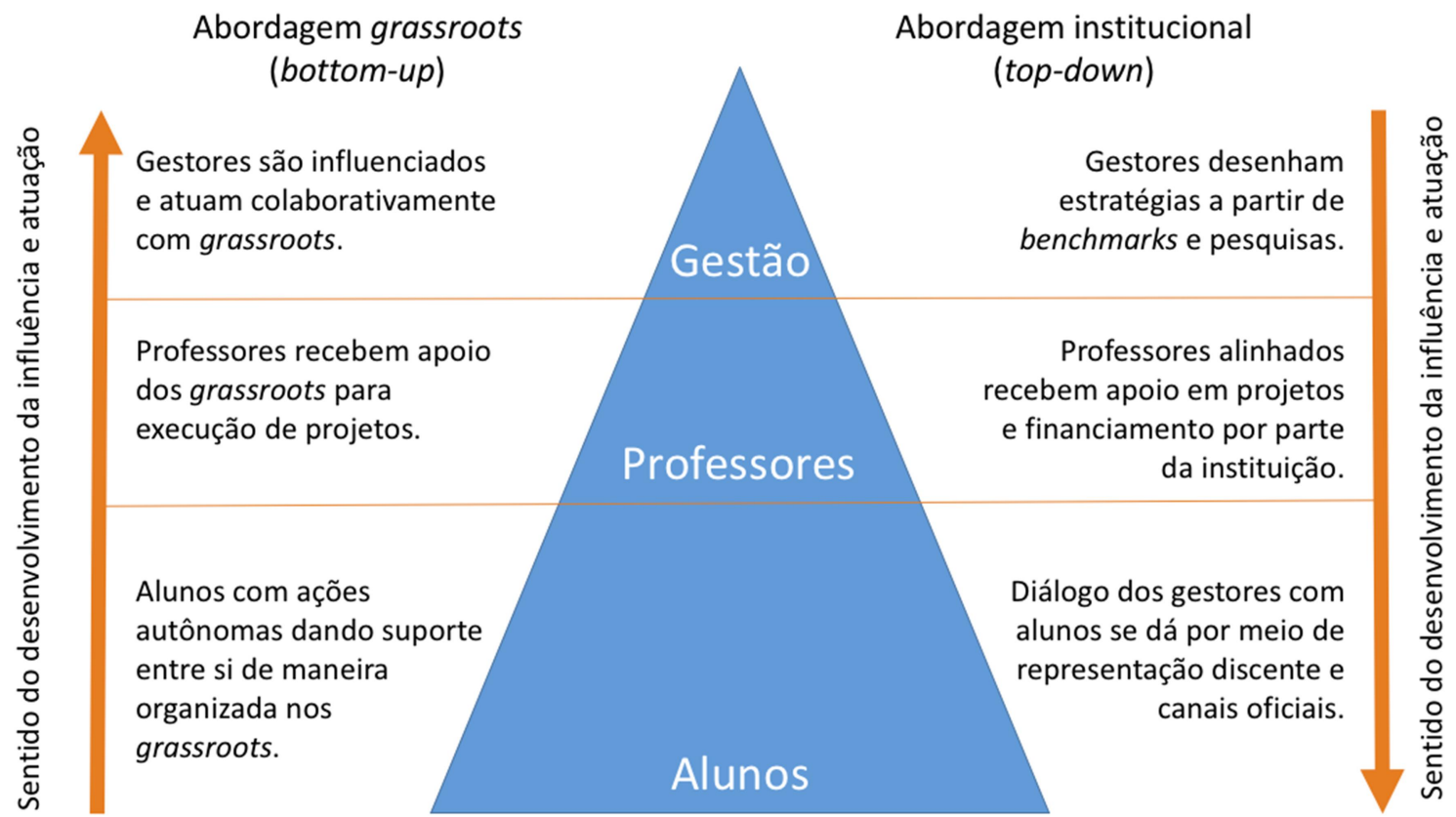

Ilustração 5 - Oposição entre abordagem bottom-up dos grassroots e top-down institucional

FONTE: Elaborada pelo autor 
No estudo "Everyday people making a difference on college campuses: the tempered grassroots leadership tactics of faculty and staff", Kezar, Gallant e Lester (2011) apresentam um marco referencial diferenciando as abordagens de transformação em universidades em três figuras, propondo uma terceira figura intermediária - que mesmo fazendo parte do corpo institucional, utiliza-se de estratégias e vinculações bottom-up para gerar mudanças: (i) liderança grassroots, (ii) abordagem institucional clássica do ensino superior e (iii) abordagem moderada (tempered approach). Para os autores, há uma forte distinção entre a abordagem grasroots de transformação e a abordagem institucional clássica.

Tabela 1 - Diferentes abordagens entre grassroots e institucional

\begin{tabular}{|c|c|c|}
\hline & Estratégias Grassroots & $\begin{array}{l}\text { Estratégias } \\
\text { Institucionais }\end{array}$ \\
\hline Inspiração e Liderança & $\begin{array}{c}\text { Força orientada por uma } \\
\text { visão }\end{array}$ & $\begin{array}{l}\text { Fóruns intelectuais; programas de } \\
\text { capacitação e desenvolvimento } \\
\text { profissional }\end{array}$ \\
\hline $\begin{array}{l}\text { Abordagem para } \\
\text { influência em ensino, } \\
\text { pesquisa e serviços }\end{array}$ & $\begin{array}{l}\text { Esforços e ações } \\
\text { centradas no aumento de } \\
\text { consciência coletiva }\end{array}$ & $\begin{array}{c}\text { Currículos de ensino; fóruns } \\
\text { intelectuais; desenvolvimento } \\
\text { profissional; trabalho em conjunto e } \\
\text { mentoria de alunos }\end{array}$ \\
\hline $\begin{array}{l}\text { Processos de } \\
\text { fortalecimento e } \\
\text { posicionamento da } \\
\text { organização }\end{array}$ & $\begin{array}{l}\text { Criação de redes de } \\
\text { contatos / } \\
\text { empoderamento de } \\
\text { outros líderes / } \\
\text { construção de } \\
\text { relacionamentos }\end{array}$ & $\begin{array}{l}\text { Trabalho em conjunto e mentoria de } \\
\text { alunos; contratação e mentoria de } \\
\text { ativistas de mentalidade alinhada }\end{array}$ \\
\hline $\begin{array}{l}\text { Construção de cultura e } \\
\text { governança }\end{array}$ & Mobilização de pessoas & $\begin{array}{l}\text { Mentoria de ativistas de mentalidade } \\
\text { alinhada; utilização de redes existentes; } \\
\text { utilização de dados; parceria com } \\
\text { stakeholders chave }\end{array}$ \\
\hline $\begin{array}{l}\text { Mecanismos de garantia } \\
\text { de recursos }\end{array}$ & $\begin{array}{l}\text { Acúmulo orgânico de } \\
\text { recursos }\end{array}$ & $\begin{array}{c}\text { Aquisição de recursos e apoio externo; } \\
\text { utilização de dados }\end{array}$ \\
\hline $\begin{array}{l}\text { Expansão e influência } \\
\text { externa }\end{array}$ & $\begin{array}{l}\text { Uso de persuasão e } \\
\text { influência }\end{array}$ & $\begin{array}{l}\text { Parceria com stakeholders chave; } \\
\text { aquisição de recursos e apoio externo }\end{array}$ \\
\hline
\end{tabular}

FONTE: Elaborada a partir de Kezar, Gallant e Lester (2011)

Quanto aos movimentos grassroots de caráter estudantil, há um crescimento no protagonismo dos mesmos em processos de transformação voltados para o empreendedorismo na universidade. Em seu estudo "StartX and the 'Paradox of Success': 
Filling the gap in Stanford's entrepreneurial culture", Etzkowitz (2013) demonstra como um movimento liderado por alunos e ex-alunos culminou em uma grande transformação na Universidade de Stanford, suprindo inclusive um gap no suporte aos empreendedores em uma universidade reconhecida como uma das principais do mundo para criação de empresas. John Maeda, que foi professor do MIT por 12 anos e presidente da Rhode Island School of Design, reforça a importância do papel desses movimentos nos processos de mudança das universidades para inovação em seu mais recente report sobre o mercado de tecnologia:

\footnotetext{
"Por ter sido presidente de uma universidade, sei por experiência própria que organizações lideradas por alunos geralmente são a mais rápida parte a se mover nas áreas relevantes para os interesses estudantis. Descobri que, especialmente em áreas como startups, design e tecnologia, o discurso é liderado muito mais pelos alunos que pelo corpo docente." (MAEDA, 2016. Tradução do autor.)
}

Burton Clark (2004) dialoga com o argumento destacando o fato de as mudanças a partir de movimentos estudantis serem um processo gradual e consequente de diversas ações autônomas que tomam forma ao passo que evoluem e se encontram. O autor caracteriza esses movimentos autônomos ganhando força com o conceito de "autonomia proativa". Para o mesmo, a autonomia proativa de movimentos estudantis carrega consigo a responsabilidade do protagonista educacional, indicando que somente se deve pedir por autonomia em momentos nos quais a intenção seja utilizar a autonomia de modo a fazer da universidade uma instituição melhor.

A consolidação do conceito começou a fazer com que a abordagem grassroots de mudança se tornasse fundamental ao imergir no contexto de empreendedorismo nas universidades. Um exemplo se encontra no já citado estudo "Creating university-based entrepreneurial ecosystems - evidence from emerging world leaders" de Graham (2014). A autora realizou um trabalho de análise com centenas de universidades e especialistas junto à iniciativa MIT Skoltech - uma parceria entre Instituto de Ciência e Tecnologia de Skolkovo (Skoltech) e MIT com a missão de "educar líderes globais em inovação, avançar o conhecimento científico e nutrir novas tecnologias para tratar de problemas críticos enfrentados pela Rússia e pelo mundo" (GRAHAM, 2014. p.1). Ao buscar identificar padrões nos processos que permitiram algumas universidades alcançarem reconhecimento global no incentivo ao empreendedorismo, encontrou dois "drivers de transformação" alinhados aos elementos citados acima: o modelo A, que ocorreu de baixo pra cima (bottom-up), liderado pela 
comunidade acadêmica, catalisado por estudantes, alumni e empreendedores da região; e o modelo B, de cima para baixo, liderado pela universidade como instituição e funcionando a partir das estruturas de atuação formais da mesma. O modelo A é apresentado em diversos momentos do estudo como 'movimento grassroots' e colocado como fundamental em muitos casos.

Aumentando a relevância no Reino Unido, tais movimentos grassroots de estudantes voltando-se para incentivo ao empreendedorismo ganharam uma nomenclatura que passou a ser recentemente utilizada por diversos movimentos na Europa. Tal nomenclatura apresenta algumas variações que ganha nomes diferentes de acordo com a região em que se encontra, sendo o nome principal as entrepreneurship societies, com variações para entrepreneurial societies; enterprise societies; entrepreneurship clubs; e-clubs. Para Smith (2011), tais organizações lideradas por alunos existem no mundo inteiro, mas não com tanta densidade quanto no Reino Unido - tendo sido a primeira a ser fundada em 1999, na Universidade de Cambridge, e hoje com mais de 70 organizações do tipo espalhadas pelo país.

\begin{abstract}
"Such groups work to drive a grassroots entrepreneurial movement within their institution, bringing together talented and passionate students from across faculties to create peer-led enterprise communities where enterprising students and young entrepreneurs support, empower and enable each other. Through these societies students are connecting across disciplines and building valuable connections, knowledge and skills from their peers and a wide range of local entrepreneurs, alumni, business support organisations and others." (SMITH, 2011)
\end{abstract}

Alguns estudos têm se aprofundado em observar os impactos gerados por estes movimentos no suporte ao empreendedorismo, tais como o "The role of entrepreneurship clubs and societies in entrepreneurial learning" (PITTAWAY et al, 2011) publicado no International Small Business Journal. O fortalecimento do movimento no Reino Unido originou o NACUE, uma organização que busca estruturar tais sociedades em um modelo unificado e sólido, oferecendo suporte e direcionamento. Em 2011, o NACUE abrangia mais de 70 sociedades, atuava em conjunto a agentes de mais de 85 universidades e representava um total de cerca de 40.000 alunos por todo o Reino Unido (SMITH, 2011). Como materiais de suporte, a organização criou diversas ferramentas, tais como: (i) Modelo de Maturidade, com um marco de progressão para direcionar as sociedades; (ii) Programa de Aprendizagem, com documentos de suporte e aconselhamento para sociedades visando apoiar o desenvolvimento das mesmas; (iii) Programa Estruturado de Mentorias, com 
conversas constantes das sociedades com os líderes da NACUE; (iii) Conferências, Comitês, Workshops e Dias de Treinamento, centrados na capacitação e formação de lideranças futuras (NACUE, 2009). O amadurecimento dos movimentos também passou a entrar na pauta de políticas públicas, como destacado pelo jornal Telegraph do Reino Unido ao apresentar a opinião de Mark Prisk - na época Ministro dos Negócios (Minister for Business and Enterprise) - que buscava compreender melhor o modelo grassroots de estudantes fomentando a criação de empresas de modo a buscar sinergias e suporte por parte do governo britânico (TYLER, 2011).

Desta forma, os movimentos liderados por estudantes de maneira grassroots têm demonstrado efetividade e amadurecimento no processo de transformação da universidade, bem como no seu direcionamento para o suporte à criação de novos negócios. $\mathrm{O}$ fenômeno grassroots liderado por alunos surge, deste modo, apresentando um caminho diferente no desenvolvimento de ações dentro da universidade, podendo ser uma via complementar às ações institucionais. 


\section{METODOLOGIA DA PESQUISA}

A presente seção tem como objetivo elucidar os procedimentos para a realização da pesquisa, cabendo a esta parte descrever de maneira organizada o método utilizado para o cumprimento do trabalho proposto. Como estrutura de referência para o processo de escolha do método, utilizou-se o modelo de Gonçalves (2007) para determinar as características que melhor se adequavam para o cumprimento, cumprimento este que considera sempre o alinhamento entre proposta da dissertação e método utilizado.

O objetivo da pesquisa tem caráter exploratório, visto que se encontra em uma situação nova e busca aprofundar-se para trazer, sob a luz do conhecimento científico, maior compreensão da realidade. Como método de pesquisa melhor adaptado a este contexto de ciências sociais aplicadas, optou-se pela utilização de um Estudo de Múltiplos Casos devido à ascensão do fenômeno em instituições diferentes e pela riqueza que tal multiplicidade traria (YIN, 2001). Os casos selecionados foram as principais organizações estudantis de fomento a empreendedorismo em universidades de pesquisa, sendo estes Núcleo de Empreendedorismo da USP, Núcleo de Empreendedores da FEA Ribeirão Preto, Liga Empreendedora da UNICAMP e Centro de Empreendedorismo da Universidade Federal de Itajubá. Os procedimentos em detalhes do método de múltiplos casos serão descritos a seguir, com base e dividem-se em: (i) procedimentos de coleta; (ii) objetivos gerais do projeto; (iii) plano de análise de dados; (iv) matriz de amarração da pesquisa. Para tal projeto, propõe-se um procedimento de coleta iniciado pelo levantamento de experiências, devido ao fato de a experiência das pessoas envolvidas no estudo apresentarem propriedade e bagagem profissional relevantes para aprofundar o conhecimento no estudo, característica que enriquece a pesquisa, como apontado por Mattar (2007). Além do levantamento de experiências, tal procedimento é precedido por uma análise descritiva com observador participante, para melhor alimentar o processo de entrevistas a serem realizadas com especialistas, visto que a pesquisa nasce de um relato de experiência proposto pelo autor observador participante.

Acredita-se, portanto, que um procedimento complementar com duas etapas - (i) relato do observador participante (foco descritivo); (ii) levantamento de experiências (foco normativo). Tal processo de coleta trata-se de uma pesquisa de campo que será realizada de maneira qualitativa, destrinchada de acordo com as etapas de levantamento: 
1. Relato do observador participante: o pesquisador, agente participativo do presente estudo, irá fornecer dados primários à pesquisa, compilando informações relativas à sua experiência à frente do Núcleo de Empreendedorismo da USP. O objetivo do relato será enriquecer o estudo com informações que possam contribuir com a busca por características de movimentos grassroots voltados para empreendedorismo na universidade.

2. Levantamento de experiência: Com entrevistas semiestruturadas, pretende-se (a) compreender características dos principais movimentos grassroots voltados para empreendedorismo no Brasil e (b) validar o Modelo de Maturidade da NACUE, citado no referencial teórico. A proposta da validação do Modelo de Maturidade é contribuir com um material que traga melhor norte para estabelecimento, fortalecimento e perenidade para tais movimentos. Neste levantamento, espera-se propor, validar e reformular um marco referencial com base em contribuições diversas.

Pretende-se, deste modo, trazer aprofundamento teórico, contribuição vivencial e percepção de especialistas que podem oferecer ao estudo uma boa perspectiva das características de um movimento grassroots voltado para empreendedorismo. Objetiva-se, como já dito anteriormente, através do processamento dos dados coletados contribuir gerando duas principais entregas: a primeira, uma abordagem bem embasada academicamente sobre $o$ processo de transformação de uma universidade se voltando naturalmente para empreendedorismo; a segunda, um marco referencial que compile, de maneira eficaz, características fundamentais para o cumprimento de um papel eficaz no estímulo ao empreendedorismo por parte de movimentos grassroots universitários. Ao final do projeto, é esperado encontrar e apresentar mecanismos que ofereçam melhor compreensão sobre o processo de transformação da universidade no incentivo ao empreendedorismo a partir de movimentos grassroots, podendo ter sua utilidade no aprofundamento e análise detalhada em estudos futuros.

\subsection{Método de apresentação do relato descritivo}

A apresentação do relato descritivo, buscado ser um dos elementos de resposta à pergunta de pesquisa 'Como os movimentos grassroots, liderados por alunos, podem desempenhar um 
papel efetivo no incentivo ao empreendedorismo em universidades de pesquisa brasileiras?', se pautou em trazer profundidade na apresentação da história da organização, nos elementos utilizados para um pleno funcionamento garantidor dos resultados já destacados e, principalmente, no relato detalhado das atividades realizadas pelo Núcleo de Empreendedorismo da USP. Acredita-se que, a partir do detalhamento descritivo, haja uma riqueza de elementos e atividades que podem vir a ser replicados por outras organizações no bom aproveitamento de seus recursos para o incentivo de empreendedorismo em Universidades. Deste modo, objetivou-se cumprir com o papel de mostrar os passos trilhados pela organização no cumprimento de um papel efetivo no contexto de ecossistemas de empreendedorismo. Assim sendo, o Relato Descritivo se dividiu em (i) gênese e motivações, (ii) estrutura organizacional e de operações e (iii) atividades desenvolvidas pela organização.

\subsection{Método no tratamento de dados do levantamento de experiências}

O levantamento de experiências teve como objetivo absorver percepções de líderes de organizações grassroots acerca do desenvolvimento de sua organização, dos principais elementos de sucesso, dos papéis a serem desempenhados pelas universidades em ecossistemas de empreendedorismo e os fatores de sobrevivência de uma organização com esse perfil. Em paralelo, também foi abordado a ferramenta Modelo de Maturidade da NACUE para organizações grassroots (entrepreneurship societies) - buscando validar o modelo e adaptá-lo a um contexto brasileiro. Para fins de contextualização, pelo menos um membro era estimulado a contar sobre a organização na abertura da entrevista de modo a nutrir o estudo com informações básicas de tal organização.

As entrevistas se dividiram em três blocos temáticos por consideração com horários, respeito ao grau de conforto do entrevistado com o tema (exemplo - alguns não se sentiam confortáveis em responder questões sobre a história da organização por falta de conhecimento) e coesão textual. Os blocos foram:

- Bloco 1: Papéis possíveis a serem desempenhados em um ecossistema;

- Bloco 2: Criação e organização do movimento grassroots;

- Bloco 3: Validação do Modelo de Maturidade NACUE. 
Quanto ao perfil dos entrevistados, o levantamento se realizou envolvendo gestores e membros de movimentos grassroots para empreendedorismo que possuíam mais de três anos de existência e se distinguiam por sólida contribuição e reconhecimento nos ecossistemas em que se inserem. Foram selecionadas as organizações Núcleo de Empreendedores da Faculdade de Economia, Administração e Contabilidade de Ribeirão Preto (FEA-RP/USP), Centro de Empreendedorismo da Universidade Federal de Itajubá (UNIFEI), Núcleo de Empreendedorismo da USP e Liga de Empreendedorismo da UNICAMP. Os entrevistados foram selecionados com base no potencial de suas experiências em agregar valor ao levantamento - sendo estes pessoas que vivenciaram profundamente a organização, assumiram lideranças de projetos e apresentavam relativa maturidade por tempo de organização. Os principais entrevistados foram líderes veteranos (que vivenciaram períodos de fundação e crise da organização), líderes atuais e corpo presidente - sendo a realização das entrevistas distribuída da seguinte maneira:

Tabela 2 - Matriz de exploração das entrevistas realizadas

\begin{tabular}{|c|c|c|c|c|}
\hline Organização & Entrevistado (E\#) & Bloco 1 & Bloco 2 & Bloco 3 \\
\hline \multirow{3}{*}{$\begin{array}{l}\text { Núcleo de } \\
\text { Empreendedores da } \\
\text { FEA-RP }\end{array}$} & $\begin{array}{c}\text { Pedro Henrique - E1 } \\
\text { (Presidente) }\end{array}$ & Respondeu & Respondeu & Respondeu \\
\hline & $\begin{array}{c}\text { Alexandre - E2 } \\
\text { (Líder atual) }\end{array}$ & Respondeu & Respondeu & Respondeu \\
\hline & $\begin{array}{c}\text { Bruna - E3 } \\
\text { (Líder veterana) }\end{array}$ & Não respondeu & Não respondeu & Respondeu \\
\hline \multirow{2}{*}{$\begin{array}{c}\text { Centro de } \\
\text { Empreendedorismo } \\
\text { da UNIFEI }\end{array}$} & $\begin{array}{l}\text { Gabriela- E4 } \\
\text { (Líder atual) }\end{array}$ & Respondeu & Respondeu & Respondeu \\
\hline & $\begin{array}{c}\text { Juliana - E5 } \\
\text { (Líder veterana) }\end{array}$ & Respondeu & Respondeu & Não respondeu \\
\hline \multirow{3}{*}{$\begin{array}{c}\text { Núcleo de } \\
\text { Empreendedorismo } \\
\text { da USP }\end{array}$} & $\begin{array}{l}\text { Rodrigo - E6 } \\
\text { (Líder atual) }\end{array}$ & Respondeu & Respondeu & Respondeu \\
\hline & $\begin{array}{c}\text { Maurício - E7 } \\
\text { (Vice-presidente) }\end{array}$ & Respondeu & Respondeu & Não respondeu \\
\hline & $\begin{array}{c}\text { Gabriel - E8 } \\
\text { (Líder veterano) }\end{array}$ & Respondeu & Respondeu & Respondeu \\
\hline \multirow{2}{*}{$\begin{array}{c}\text { Liga de } \\
\text { Empreendedorismo } \\
\text { da UNICAMP }\end{array}$} & $\begin{array}{c}\text { Eric - E9 } \\
\text { (Líder atual) }\end{array}$ & Não respondeu & Não respondeu & Respondeu \\
\hline & $\begin{array}{c}\text { Ciro - E10 } \\
\text { (Presidente) }\end{array}$ & Respondeu & Respondeu & Respondeu \\
\hline
\end{tabular}

FONTE: Elaborado pelo autor.

A análise do conteúdo, procedimento selecionado para tratamento dos dados - utilizando o processo metodológico de Bardin (CAREGNATO; MUTTI, 2006), se fez compilando as percepções dos membros para questões históricas da organização e referente aos papéis desempenhados (blocos 1 e 2) - de modo a evitar repetição desnecessária de informações descritivas. O bloco 3, por ter um teor avaliativo e não ser relativo à organização do 
participante, foi avaliado de maneira individual - utilizando a Escala Likert para levantar os dados. Sendo um estudo exploratório qualitativo, não foi considerado o uso de tratamento quantitativo da Escala de Likert, visto que o tamanho da amostra poderia não ser representativa. Deste modo, o bloco 3 foi observado de maneira mais qualitativa e, quanto às notas da escala, foram tratadas a partir do uso de calculo de moda - complementando com uma análise de distribuição das notas - de modo a identificar possíveis tópicos que menos consistência possuía (ALEXANDRE et al, 2003).

\subsection{Matriz de amarração da dissertação}

Com fins de melhor organização da estrutura da dissertação, foi utilizado o modelo de Mazzon (1981), que propõe o uso da Matriz de Amarração como um instrumento de avaliação de aderência entre os elementos de um estudo científico nas pesquisas de Administração (TELLES, 2001). A adaptação do modelo se estruturou com a finalidade de demonstrar coerência entre a pergunta de pesquisa, seu desdobramento em hipóteses, os objetivos da dissertação e os métodos utilizado.

Tabela 3 - Matriz de Amarração da Dissertação

\begin{tabular}{|l|c|c|c|}
\hline \multirow{2}{*}{ Pergunta de Pesquisa } & Hipóteses & Objetivos & Método utilizado \\
\hline & $\begin{array}{c}\text { H1 - Há movimentos } \\
\text { grassroots de impacto no } \\
\text { Brasil }\end{array}$ & $\begin{array}{c}\text { Apresentar a gênese dos } \\
\text { movimentos no Brasil }\end{array}$ & $\begin{array}{c}\text { Relato participante }+ \\
\text { Levantamento de } \\
\text { experiências (Bloco 2) }\end{array}$ \\
\cline { 2 - 4 } $\begin{array}{l}\text { Como os movimentos } \\
\text { alunos, podem } \\
\text { desempenhar um papel } \\
\text { efetivo no incentivo ao } \\
\text { empreendedorismo em } \\
\text { universidades de } \\
\text { pesquisa brasileiras? }\end{array}$ & $\begin{array}{c}\text { H2 - Os grassroots } \\
\text { possuem práticas } \\
\text { ao empreendedorismo }\end{array}$ & $\begin{array}{c}\text { Descrever boas práticas } \\
\text { de incentivo }\end{array}$ & $\begin{array}{c}\text { Relato participante }+ \\
\text { Levantamento de } \\
\text { experiências (Bloco 1) }\end{array}$ \\
\cline { 2 - 4 } & $\begin{array}{c}\text { H3 - Um modelo de } \\
\text { maturidade pode auxiliar } \\
\text { o desenvolvimento de } \\
\text { grassroots no Brasil }\end{array}$ & $\begin{array}{c}\text { Validar um Modelo de } \\
\text { Maturidade para } \\
\text { grassroots brasileiros }\end{array}$ & $\begin{array}{c}\text { Levantamento de } \\
\text { experiências (Bloco 3) }\end{array}$ \\
\hline
\end{tabular}

FONTE: Elaborado pelo autor, baseado em Telles (2001). 


\section{LEVANTAMENTO DE DADOS}

Nesta etapa serão apresentados os dados levantados nos dois momentos da metodologia do estudo: (i) Relato descritivo com observador participante e (ii) Levantamento de experiências.

\subsection{Relato Descritivo: Núcleo de Empreendedorismo da USP}

Como primeiro elemento metodológico, será feito um Relato Descritivo sobre o Núcleo de Empreendedorismo da USP, abordando (i) sua gênese e motivações, (ii) a estrutura organizacional e de operações e (iii) atividades desenvolvidas pela organização. Buscou-se profundo detalhamento na abordagem para cumprir com o objetivo de ser um elemento direcional a outras organizações grassroots que busquem se desenvolver em suas universidades.

\subsubsection{Gênese e Motivações}

Os primeiros movimentos que vieram a originar o Núcleo de Empreendedorismo da USP ocorreram por volta dos anos 2010 e 2011, com alunos de diversas unidades da Universidade de São Paulo buscando empreender e compartilhar experiências entre si. O primeiro registro de atividades é a apresentação de slides de convite para o que seria o início das atividades do NEU - cuja data de formação informada é Setembro de 2010 (STARTUPAPO, 2011). O período de efervescência de 2010 e 2011 foi marcado por alguns fenômenos que trouxeram a temática para o cotidiano dos universitários junto com uma atmosfera vibrante que incentivava o empreendedorismo: (i) em 2009, a startup Buscapé - criada por alunos da Poli - era vendida por mais de 300 milhões de dólares (AGUILHAR, 2015); (ii) em 2010, o filme "A Rede Social" (que se tornou um blockbuster), contava a história de sucesso do Facebook, com ênfase no nascimento da empresa nos corredores de Harvard; (iii) ganhavam relevância os livros Lean Startup (RIES, 2011), Design Thinking (BROWN, 2010) e Business Model Generation (OSTERWALDER e PIGNEUR, 2010), que estimulavam o exercício da criação de startups por meio de produtos minimamente viáveis e prototipagem rápida; (iv) com o incentivo à rápida prototipagem e diminuição de barreiras tecnológicas, surgia um grande volume de atividades e eventos de criação de startups rapidamente - tais como o Startup 
Weekend, que em 2011 influenciava o nascimento a um dos principais aplicativos do país, o Easy Taxi (GAZZONI, 2014).

Antes da formalização do Núcleo, duas organizações envolviam o que viria a ser o NEU - a Rede USP de Novos Negócios (RUNN) e o Centro Minerva de Empreendedorismo. A Rede USP de Novos Negócios teve seu surgimento com alunos da Faculdade de Economia, Contabilidade e Administração da USP (FEA-USP) interessados em conectar alunos empreendedores, compartilhar experiências e realizar algumas atividades inspiracionais como competições de ideias e palestras. Já o Centro Minerva de Empreendedorismo surgiu em 2002, na Escola Politécnica da USP (Poli-USP), sob iniciativa de dois professores José Siqueira e Celso Furokawa voltado para capacitação dos alunos em empreendedorismo por meio de um programa voluntário. O Centro, que inicialmente tinha as características de um movimento grassroots tornou-se institucional ao ser incorporado pela Agência USP de Inovação com a proposta de amplificar suas atividades por toda universidade - após a transição, as atividades do centro se tornaram menos expressivas, embora tenha tentado revitalização buscando alunos da escola de engenharia em 2011 e realizando atividades em parceria com o NEU, mas sem destacado sucesso (FERMINO, 2011; USP, 2012). No caso do Núcleo, o posicionamento firme quanto à não dependência de forças ou interesses institucionais garantiu relações estratégicas que compreendiam a função da organização. Uma das situações que reforçam tal ponto foi a cobertura do Núcleo por um veículo de comunicação institucional, bem como sua replicação em meios de instituições que poderiam possuir receios diversos acerca de um canibalismo dentro de ambientes de apoio na universidade, como a incubadora CIETEC, que apresentou em seu site a matéria "Empreendedorismo na USP: alunos se aventuram no universo das startups" (OLIVEIRA, C.; CASTRO, T., 2015), no qual o NEU tem destaque junto à incubadora no apoio a empresas nascentes.

A troca de experiências e a aproximação entre os alunos dos dois movimentos grassroots gerou uma fusão que originou o Núcleo de Empreendedorismo da USP. Absorvendo as características dos dois modelos, o NEU se estruturou em três pilares: inspiração, capacitação e conexão. Os três pilares eram fundamentais para a missão que veio a ser estabelecida pela organização: desenvolver uma cultura de empreendedorismo dentro da USP. Aqui, cabe ressaltar que orientadores do Núcleo chamaram a atenção pelo caráter da missão e o alinhamento com as reais atividades - em tom de crítica construtiva, foi dado o alerta de que ao se propor atuar na Universidade de São Paulo, deve-se considerar todos os 
seus campi, unidades, escolas e envolvidos. Por características de sua origem, o NEU atua principalmente nas unidades FEA e Poli (além de arredores), do campus Cidade Universitária, muitas vezes limitando sua atuação e afirmando ter uma missão voltada para a USP com um todo - desafio que devidamente recebeu o alerta presente na frase inscrita na Praça do Relógio da USP: "No universo da Cultura, o centro está em toda parte", frase de Miguel Reale que traz a importância de disseminar o saber por todas as partes, atentando-se ao risco de se dizer parte central de um ambiente amplo que carrega o universo no nome, a universidade (RITONDALE, 2008).

Ao passo que a organização foi amadurecendo com suas entregas (que serão detalhadas em tópicos à frente), o NEU passou a se tornar mais reconhecido e com estrutura jurídica configurada, apropriando-se de um CNPJ e criando raízes mais sólidas. Nos primeiros anos, a escassez de recursos incluía a falta de uma sede própria e de financiamento para executar projetos, porém, dialogando com o apresentado por Clark (2004), a autonomia proativa se fortaleceu com resiliência e consistência nas entregas, ganhando a confiança de agentes estratégicos da USP. Ao passo que as entregas se desenvolviam, membros do corpo docente passaram a se aproximar mais da organização e, inclusive trazer alinhamento dos interesses da organização com planejamentos formais da Universidade, como relatado em uma matéria para o Jornal Estado de São Paulo, que destacava o NEU como pilar central de um celeiro de startups formadas na região (AGUILHAR, 2015b). Em outro relato, destacou-se o desenvolvimento da organização por seus esforços autônomos trazendo reconhecimento e engajando diversos professores orientados à terceira missão:

\footnotetext{
"Plonski, um professor e engenheiro envolvido profundamente com a promoção da inovação tecnológica no país pelo menos há duas décadas, conta que tomou conhecimento do NEU por um cartaz afixado numa parede da FEA, a Faculdade de Economia, Administração e Contabilidade da USP. A mensagem do cartaz era um convite para uma palestra de Fernando Reinach, biólogo molecular e professor da USP que se tornou um executivo de fundos de investimento para inovação, e que falaria justamente sobre o Fundo Pitanga. Final da tarde, a sala da Congregação da FEA estava tomada por uns 100 rapazes e moças que queriam saber tudo do Fundo Pitanga e de recursos para inovar e empreender." (RUA, 2016)
}

Tal confiança se desdobrou na formalização de professores orientadores, apoio intensivo da Pró-Reitoria de Pesquisa e, mais importante, um convite para estabelecer a operação sediando-se no Inovalab da Poli-USP, laboratório de inovação da escola de engenharia centrado em empoderamento estudantil para tecnologias. O envolvimento com o Inovalab 
se mostrou como um dos principais momentos do Núcleo, amadurecendo as operações e trazendo à tona um movimento que originou uma frase célebre de um dos professores que coordena do laboratório: 'Aqui os Nerds se encontraram com os empreendedores e isso mudou a cara da inovação na escola de engenharia. NEU e Inovalab é um casamento perfeito.' (retirado de uma conversa informal).

Conforme a espiral positiva de bom posicionamento e atração de pessoas talentosas foi ganhando tração, os resultados se tornaram maiores e de reconhecimento internacional, como o resultado de um dos membros do NEU ganhando uma competição internacional de tecnologia na Europa sendo amplamente divulgado pela universidade e pela Associação dos Engenheiros Politécnicos (AEP, 2016), que muitas vezes apoiou o Núcleo com recursos estratégicos.

Alguns pontos são de importante destaque quando se fala da gênese e da evolução do Núcleo de Empreendedorismo da USP:

-Não limitar as ações justificando com a insuficiência de recursos - parte do fortalecimento de uma organização grassroots para empreendedorismo se prova a partir da capacidade dos membros de organizar e angariar recursos, se adaptando às condições e crescendo a partir dos recursos possíveis existentes.

-Poder das interfaces - a cultura de colaboração e compartilhamento apresentada com grande reforço no embasamento teórico sobre ecossistemas reflete no papel que as interfaces tiveram no NEU. Construir relações sinérgicas com laboratóritos, agentes parceiros, inter-organizações entre outras. foi fundamental para a boa execução das propostas.

-Engajamento de longo prazo liderado por empreendedores - algumas lideranças características por serem compostas por alunos empreendedores (na época donos ou futuro donos de algum negócio) - ficaram à frente do NEU por cerca de 3 anos, postura incomum em movimentos universitários, mas que se fundamenta nas propostas de Brad Feld (2012), também destacadas no referencial teórico. 


\subsubsection{Estrutura organizacional e de operações}

Descrever a estrutura organizacional e o formato da operação do NEU pode ser de grande valia para movimentos que buscam sua replicação, ou até mesmo para gestores de universidades que estão em busca de uma compreensão maior sobre o formato de um movimento desse tipo. Espera-se nesse tópico també cobrir os desafios enfrentados e as soluções até o momento desenvolvidas para o mesmos.

O Núcleo de Empreendedorismo da USP, como natural dos movimentos grassroots citados na teoria, se desenvolveu sob o modelo de trabalho voluntário, independente dos cargos desempenhados, e com carga de trabalho flexível envolvendo 20 horas semanais. A ausência de remuneração se mostrou tanto negativa quanto positiva - negativa por prejudicar a atuação plena de alguns membros cuja limitação financeira se tornou impeditiva, mas positiva por repelir membros que iriam buscar o Núcleo por pura remuneração de fácil desempenho. Tal limitação influenciou também no nível de engajamento dos membros, sendo que é percebida uma motivação maior em membros que estão ali basicamente ligados à missão do Núcleo.

A operação geralmente envolve 10 a 15 pessoas de origem multidisciplinar, mas em momentos de dificuldades o NEU já chegou a ter 2 membros - e a consistência e resiliência dos mesmos garantiu a sobrevivência da organização. A rotatividade de membros sempre foi o principal desafio, sendo a manutenção da gestão e a transferência do conhecimento um problema grave do histórico do Núcleo. Para minimizar tais riscos, tem-se uma atenção maior à transição de gestão, refletindo e dialogando sempre com os membros sobre a continuidade dos mesmos. Uma outra percepção foi o problema ligado às consequências da liderança de longo prazo: a figura de um presidente durante muito tempo de organização fazia com que os membros em ascensão não ficassem motivados a continuar no Núcleo, visto que não conseguiriam ocupar o posto de presidente devido a uma inferior experiência natural da discrepância de tempo de trabalho. Para isso, foi pensada em uma transição de modo a manter o certos papéis positivos deste líder, mas permitir a evolução dos membros tal presidente tornou-se presidente do conselho, passando a influenciar em questões estratégicas e políticas, ao passo que os membros em ascenção tiveram oportunidade de ocupar cargos de presidência e garantir uma cultura de transição. 
A estrutura formal se fez com ênfase na horizontalidade, com alguns poucos cargos sendo hierarquicamente superiores para garantir maior alinhamento estratégico, maturidade e visão de longo prazo. O organograma tem somente três níveis: membros, presidência (presidente e vice-presidente) e conselheiros (4 ex-membros ou empreendedores da rede e 4 professores). São realizadas eleições para fins de formalização, porém, a definição de cargos e funções habitualmente é realizada a partir de diálogos prévios e consenso, de modo a garantir uma transição de conhecimento mais bem estruturada. A seleção do corpo do conselho é feita também de maneira consensual, visando o papel estratégico de cada conselheiro e sendo revisitada no período de eleição. Para a presidência, é esperado um período de gestão de, no mínimo um ano (enfatizando sempre a importância de compromissos de longo prazo). Geralmente há um processo de seleção formal semestralmente e outro informal aberto durante o ano inteiro, no qual entram membros pontuais que se aproximaram do Núcleo de maneira específica. Após a entrada dos membros, é feito um período de treinamento de aproximadamente 15 dias, onde são reforçados os pontos culturais da organização, os projetos e, principalmente, os conteúdos necessário para apoiar empresas nascentes - que pode ser considerado como um mini-curso de empreendedorismo para trazer massa crítica aos entrantes. Um dos grandes problemas que dialoga com o principal desafio da rotatividade - era o estabelecimento da cultura do NEU em um ambiente multidisciplinar. Por sua gênese ter sido baseada entre as escolas de engenharia e de negócios, o Núcleo carrega consigo o que é chamado de 'cultura de execução', na qual a operação é orientada para resultados e prazos, característica não muito comum para membros de outras áreas, especialmente de humanas e biológicas, que acabam tendo dificuldade em adaptar-se. Nisso surge o desafio às lideranças de saber lidar com perfis muito distintos, com certo nível de micro-gerenciamento e outras barreiras que vão surgindo na adaptação cultural. No momento de produção do presente relato, ainda se mostrava essa um dos maiores problemas do NEU, que inclusive impactavam negativamente o clima organizacional da operação.

A comunicação externa é feita a partir de redes sociais com alcance de dezenas de milhares de pessoas. Além disso, o destaque e reconhecimento da organização garantiram maior abertura nas comunicações institucionais, que apoiam e alavancam a comunicação para todos os campi da Universidade (USP, 2015).

Traços da cultura de operação são um dos principais marcos do NEU. A característica da cultura da organização é percebida como um forte elemento para atração de talentos e para 
entrega de serviços de qualidade. Baseando-se no modelo de disseminação de cultura da empresa Facebook (SANDBERG, 2015), diversas mensagens informais são espalhadas pelo ambiente físico e digital do Núcleo (além de repetidas constantemente no dia-a-dia), com o foco de motivar e fortalecer o ethos da operação, sendo algumas delas:

- Ideias são commoditie, a execução delas não.

- The way to get started is to quit talking and start doing.

- Se tudo está sob controle, possivelmente você não está rápido o suficiente.

- Pare de chorar e execute!

- Always deliver more than expected.

- Get out of the building!

- The value of an idea lies in the use of it

A cultura do Núcleo de Empreendedorismo da USP se desenvolveu centrada em autonomia e empoderamento de lideranças, utilizando um modelo configurado pela empresa Spotify (HARASYMCZUK, 2014) que definiu as seguintes influências:

(a) Gestão por projetos: em vez de uma gestão centralizada em gestores de áreas, o NEU se organiza por projetos - cada projeto se configura baseado em algum, ou intersecção de mais de um, pilar (inspiração, capacitação e conexão). Cada projeto tem um líder, chamado de captain, que responde pela gestão do mesmo e se comunica com a presidência em caso de problemas, dificuldades ou oportunidades.

(b) Alinhamento semanal: semanalmente é feito um checkpoint, baseado na metodologia Scrum (RIGBY, SUTHERLAND e TAKEUSHI, 2016), no qual é alinhado o andamento do projeto e planeja-se as entregas para a próxima semana. Tal reunião é feita em pé, de maneira rápida (15 minutos), visando apenas alinhar todos da operação. A prática garantiu ganhos altos em produtividade e comunicação interna, fazendo com que compromissos fossem cumpridos e que o nível de entrega aumentasse - sem ser um modelo desgastante de reunião.

(c) Cultura de autonomia: qualquer membro, independente da hierarquia, pode propor um novo projeto - e assumir a capitania do mesmo. Os projetos, de caráter pouco dependentes, podem testar suas próprias abordagens - em ferramentas, redes de contato, organização funcional entre outras -, que são 
compartilhadas com as outras equipes quando dão certo, de modo a gerar maior ganho de conhecimento para a organização. Cabe reforçar que a cultura de autonomia é compensada por uma grande ênfase em comunicação interna e alinhamento estratégico.

\subsubsection{Atividades desenvolvidas}

Complementando o relato descritivo no qual já se cobriu (i) fatores que motivaram o surgimento, (ii) o histórico do amadurecimento da organização, (iii) elementos da operação e (iv) estrutura organizacional, acreditou-se na suma importância da descrição dos projetos que fizeram o Núcleo de Empreendedorismo da USP se destacar como movimento grassroots. Os projetos, como já apresentado anteriormente, se dividiam em inspiração, capacitação e conexão - dialogando com o processo natural de amadurecimento do empreendedor. Cabe aqui destacar que foi vivenciado pela organização tal amadurecimento de empreendedores que passaram pelos três pilares: inicialmente se motivando com ações inspiracionais, buscando capacitação para transformar uma ideia em negócio e, por fim, sendo conectados à rede de contatos de modo a fazer crescer a empresa. A partir do momento de maturidade e conexão, um grande fato natural foi o retorno dos mesmos para as atividades de inspiração, capacitação e conexão, mas agora como empreendedores maduros retornando ao ambiente que os ajudou no começo - espiral positiva apresentada por Isenberg (2011) e colocada no referencial teórico sobre desenvolvimento de ecossistemas de empreendedorismo.

\section{a) Inspiração}

A proposta do pilar "inspiração" é estimular o interesse dos alunos em empreender. Diversas iniciativas ocorreram nesse sentido - palestras, encontros, vídeos nas bases das redes sociais, divulgação de cases USP de sucesso, contato direto com empreendedores USP, contato com outros empreendedores. Utilizando o modelo de Isenberg (2011), o foco da inspiração envolve a questão de desenvolvimento de uma cultura mais aberta a empreendedorismo e na atração de capital humano para a realidade de criação de empresas. Alguns casos têm formato mais sólido e construíram certo histórico dentro da organização:

(i) Startupapo: O principal evento do Núcleo de Empreendedorismo da USP, atualmente com bases mais capilarizadas, sendo executado em diversos institutos da 
universidade e ultrapassando 20 edições. O Startupapo nasce com o objetivo de aproximar a realidade de empreendedores, geralmente ex-alunos USP, com a realidade dos alunos, trazendo os empreendedores para contar suas histórias de maneira mais próxima e abrindo para um bate-papo. O formato se estrutura em 2 ou 3 empreendedores contanto, em 20 minutos cada, como construíram sua empresa e os principais fatos relacionados a esse processo - desafios, problemas, medos, angústias, paixões, resultados e impacto. Após as falas, os alunos tem espaço livre perguntar abertamente sobre qualquer coisa relacionada a empreendedorismo - um momento onde os mesmos aprendiam bastante e ficavam mais inspirados por receber conselhos e encorajamento por parte dos empreendedores. $\mathrm{O}$ projeto se tornou tão relevante que resultou em um livro, disponível na amazon (FERMINO, 2014). Público alvo de geralmente 50 a 100 alunos.

(ii) Keynote: Os keynotes começaram a surgir com o crescimento do NEU. Grandes empresas passaram a procurar ou se interessar em utilizar o Núcleo como intermediário para a realização de palestras de maior impacto, tal fato ocorreu pelo aumento da capilaridade da organização dentro da USP e, também, pelo amadurecimento da rede de contatos - onde ex-membros do NEU atuavam em grandes empresas e buscavam conectálas com a organização já reconhecendo seu potencial de impacto. O formato se estrutura em uma palestra de aproximadamente 1 hora, com maior profundidade e geralmente com temas mais específicos do que apenas o processo de construção da empresa. Alguns casos famosos, como o vice-presidente de marketing da Rovio (Angry Birds) vindo da Finlândia dando uma palestra na USP fortalecem a importância da maturidade da rede, visto que o mesmo veio devido a um ex-membro do NEU atuar como um dos principais gestores da empresa. Público alvo de geralmente 100 a 200 alunos.

(iii) Almoço Empreendedor: A intenção dos almoços é construir uma cultura sólida de, em um determinado local, em determinada data do mês, sempre terão empreendedores almoçando com alunos USP. Por enquanto, tal cultura não foi construída, mas muitos almoços já ocorreram. O formato tem duração de, aproximadamente, $1 \mathrm{~h} 30$, onde 1 empreendedor é convidado e 5 alunos são selecionados para estar presentes. A proposta é que a conversa seja bastante próxima e pessoal, mais profunda que o modelo do Startupapo, visto que o número reduzido de alunos faz com que a troca seja bastante personalizada, o que agrega bastante em termos de inspiração (e inclusive em capacitação e conexão, devido 
à oportunidade de conselhos mais diretos, indicações de conteúdos e formalização de redes profissionais).

(iv) Conteúdo inspiracional direcionado - Por meio de redes sociais e algumas iniciativas pontuais, a organização busca produzir e direcionar, diariamente, conteúdo focado para empreendedores, especialmente para alunos que estão começando ou interessados em montar um negócio. Os materiais vão de links para matérias, textos, artigos até e-books e guias melhor estruturados. O público atingido estimado está ligado à página da organização no site facebook, que possui uma base de quase 10000 seguidores (uma das principais páginas de organização estudantil do Facebook), com posts que já chegaram a ter centenas de milhares de visualizações. O crescimento da base de seguidores se deu de maneira orgânica, baseada em forte trabalho de curadoria de conteúdo - com investimentos financeiros para aumento de alcance ocorrendo em raras situações (estima-se que, durante toda a história da organização, não se tenha chegado à soma de R $\$ 2000$ gastos em alavancagem de presença digital).

(v) Interface com salas de aula: aproveitando o interesse de alguns professores em empreendedorismo - inclusive algumas disciplinas centradas em empreendedorismo, o Núcleo de Empreendedorismo da USP buscou sinergias de modo a participar ativamente de momentos das disciplinas nas quais poderiam ser realizadas atividades de inspiração. A sinergia proposta foi aproveitar a abertura de professores de modo a trazer palestrantes da rede do Núcleo de modo a trazer inspiração e posicionar a organização em sala de aula. A interface com disciplinas se fortaleceu a ponto de membros do NEU se tornarem monitores de disciplinas ligadas a empreendedorismo e influenciarem de maneira muito profunda. Foi percebido que a interação com alunos dentro de sala de aula trazia bastante resultado, sendo que algumas das startups de sucesso vieram desse tipo de interação - sendo assim a ação considerada como fundamental para o cumprimento da missão.

Outros formatos são constantemente testados e busca-se sempre oferecer liberdade para parcerias com outras instituições da USP, como empresas juniores, grêmios e associações, para prover suporte na construção de programas que tragam inspiração ao aluno interessado em empreender. As parcerias geraram bons resultados, como competições de ideias envolvendo mais de uma escola, palestras organizadas em parcerias com grêmios e outras iniciativas. Com o passar do tempo, o alcance das atividades inspiracionais passou a atrair 
uma ampla gama de patrocinadores - como no festival de empreendedorismo, que trouxe uma associação de cooperação internacional, empresas de tecnologia, fundação vanzolini entre outros (VANZOLINI, 2016).

\section{b) Capacitação}

Este pilar busca aproveitar a reconhecida massa crítica da Universidade de São Paulo para oferecer o maior nível de suporte técnico e ferramental aos alunos interessados em criar negócios. O fato de a USP oferecer bastante conteúdo voltado a diversas áreas faz com que seja possível acionar alunos e professores que possuem distintas competências capazes de sanar dúvidas e oferecer materiais ricos. No modelo de Isenberg (2011), a capacitação abrange a questão do suporte direto ao empreendedor e educação para o capital humano do ambiente em questão - foco dos projetos que neste tópico serão apresentados. Assim como o pilar de inspiração, algumas entregas já têm formato melhor estabelecido e resultados comprovados, que são as seguintes:

(i) Levantamento de disciplinas ligadas a empreendedorismo para matrícula dos alunos de graduação: a equipe do Núcleo de Empreendedorismo da USP analisou a base das disciplinas nos sistemas da Universidade e selecionou as mais úteis entre as escolas que poderiam ter relação com o ambiente de negócios (Faculdade de Administração, Economia e Contabilidade da USP; Escola Politécnica da USP; Escola de Comunicação e Artes da USP; Instituto de Matemática e Estatística da USP; Faculdade de Filosofia, Letras e Ciências Humanas da USP; Instituto de Psicologia da USP; Faculdade de Direito da USP; Faculdade de Arquitetura e Urbanismo da USP). Ao todo, foram cerca de 70 disciplinas levantadas de maneira colaborativa envolvendo diversos alunos de modo a oferecer melhor curadoria - o material está disponível no site do núcleo (NEU, 2016). Com planos futuros de consultas e discussões com docentes, colaboração aberta de alunos e atualização anual.

(ii) NEU Startup Lab - Programa de desenvolvimento de negócios - semelhante a uma pré-aceleração (RIBEIRO, PLONSKI e ORTEGA, 2015) para alunos que apresentam apenas a ideia em estágio inicial. O programa usa uma diversidade de conteúdos para oferecer suporte aos alunos no desenvolvimento de suas ideias, transformando-as em empresas - contando com a infraestrutura do Inovalab para manter os projetos em um ambiente propício e cercado de outros negócios nascentes (bem como uma pequena 
biblioteca do NEU composta por livros ligados ao desenvolvimento de negócios de base tecnológica). Há também uma forte participação de mentores para direcionar e oferecer ajuda a questões pontuais. O programa tem como resultado mais relevante o de um aluno do curso de Fisioterapia, característico pela ausência de contato com disciplinas envolvendo negócios, que foi capacitado e direcionado a transformar sua ideia - uma plataforma virtual de conexão de cuidadores com famílias que precisavam desse tipo de serviço - em empresa. A empresa surgiu, começou a levantar base de clientes e passou por uma fusão com um grupo melhor posicionado do mercado, no qual o aluno passou a exercer a função de CEO (Chief Executive Officer, se assemelha à presidência). Diversos outros casos de sucesso passaram a ocorrer com o ganho de experiência da organização em desenvolver empresas de base tecnológica a partir do programa de pré-aceleração. Foi considerado importante apresentar a estrutura do programa para direcionar outras organizações que tenham interesse em replicá-lo:

- Fase 1 - Compreensão do mercado: como muitas vezes o aluno não possui vivência do mercado no qual pretende-se inserir, a primeira etapa se concentra em aproximar o mesmo do mercado. Nesta fase, o aluno é solicitado buscar informações sobre o mercado, analisar concorrentes, estudar tecnologias existentes em escala global, conversar com pessoas do mercado buscando feedbacks e compreender as dinâmicas (fornecedores, clientes, gargalos e desafios). Alguns mentores inclusive direcionam os alunos a trabalharem no setor, de modo a ganhar experiência, maturidade e know-how sobre os minúcias do mercado. Este é um momento de elevada dispersão, devido ao fato de muitos estarem apenas superficialmente encantados com a ideia - e com as primeiras entregas e desafios perdem o interesse. Tal dispersão é considerada importante pois é percebida como parte do aprendizado do aluno, que muitas vezes não estava preparado em termos de interesse e resiliência para a empreitada. É uma etapa na qual algumas atenções já são dadas à necessidade de uma equipe complementar, envolvendo pessoas que possam assumir área técnica/produto, área de gestão/negócios e área de criação/design - não necessáriamente exigindo que haja pessoas para os três pontos, mas apontando ser necessário e amadurecendo a necessidade de construção de um time sólido.

- Fase 2 - Obsessão pelo usuário: inspirado por um investidor reconhecido internacionalmente, Paul Graham, o termo user obsession é central na segunda fase 
do modelo. Nesta etapa, o aluno é direcionado a realizar entrevistas imersivas para compreender a 'dor do usuário' que se pretende resolver. As entrevistas buscam compreender, baseado no programa Customer Discovery - NEXT powered by Google for Entrepeneurs (NEXT, 2013) - (i) como foi a experiência na última vez em que o problema foi vivenciado, (ii) como a pessoa soluciona hoje, (iii) quais os principais porquês ligados ao problema (aplicação dos '5 porquês' para compreender o que originou o problema). É aconselhada a realização de dezenas de entrevistas - com alguns projetos realizando mais de 60 delas. Este é o momento em que o NEU considera existir o amadurecimento da proposta de valor dos negócios, pois é o momento no qual os alunos compreendem a 'dor do usuário' que irão resolver e como melhor construir uma solução. Neste estágio, espera-se que haja um 'alinhamento problema-solução' para avançar - sendo comum ocorrerem pivots, movimentos que mudam toda a proposta de valor do negócio.

- Fase 3 - Validação do modelo: Aqui são realizados experimentos buscando validar a proposta de valor, prestando o serviço em pequena escala, apresentando o produto em fase de protótipo funcional, criando landing pages para introduzir a proposta no mercado. É a realização dos MVP's (minimum viable products - produtos mínimos viáveis), produtos mínimos viáveis, estágios do produto mais centrados em maximizar a aprendizagem por meio de feedbacks de interação com o mercado. Considera importante a leitura do livro Lean Startup (RIES, 2012) e do texto 'Minimum Viable Product is not a Product, is a Proccess' (BRIKMAN, 2016) para evitar confusões nesse estágio. Com o amadurecimento da proposta de valor e interações com o mercado, espera-se o avanço da empresa para um modelo de comercialização que passe a garantir a formalização da transição de uma ideia para um negócio.

- Fase 4 - Conexão com o ecossistema: Mais maduros e com resultados reais trazidos da validação, os alunos são direcionados para relações comerciais e contatos profissionais com pessoas interessantes do ecossistema de empreendedorismo - potenciais primeiros clientes, investidores, parceiros estratégicos entre outros. Também é incentivada a participação em competições de negócios, buscando ganhar mais feedbacks, conhecer pessoas e, em alguns casos, se beneficiar dos recursos ligados às premiações (viagens, capital financeiro, exposição entre outros.). Até este momento, geralmente as startups se desenvolvem dentro do Inovalab, aproveitando do contato com outros projetos, professores e 
mentores frequentes, porém, o amadurecimento comercial geralmente traz a necessidade de um escritório. O NEU possui diversos contatos ligados a escritórios, buscando assim conectar a empresa a tais locais para maximizar resultados e fortalecer a rede.

(iii) Cursos e workshops - Eventos curtos realizados com a proposta de trazer algum conhecimento específico sobre temas que a organização considera interessante para a capacitação dos alunos, tais como noções sobre o mercado de investidores, desenvolvimento de mercado e metodologias para inovação. Workshops mais longos, como o programa de embaixadores - que visa formar pessoas qualificadas para disseminar conteúdos - também ocorrem, mas de maneira menos periódica.

(iv) Programas em parceria com apoio financeiro - Uma das principais experiências em termos de resultados foram os programas envolvendo parceiros capazes de oferecer suporte financeiro aos projetos nascentes. Geralmente ocorrendo com o envolvimento de algum departamento institucional, uma organização privada e tendo o NEU como agente ligado ao processo de aceleração, suporte aos alunos e disseminação da campanha, os programas trazem maior motivação aos alunos pelo incentivo financeiro - que muitas vezes eram equivalentes a um primeiro investimento (entre $\mathrm{R} \$ 10.000,00$ e $\mathrm{R} \$ 60.000,00$ ). Se mostrou uma grande fonte de empresas nascentes de base tecnológica que conseguiram sustentar seus avanços de maneira sólida e bem sustentada. O principal projeto foi o programa Academic Working Capital (AWC), realizado em parceria com o departamento de mecatrônica da Escola Politécnica da USP e Instituto Tim (TIM, 2016).

(v) Curso online de criação de startups - Visando atingir um maior número de pessoas - alunos e comunidade externa interessada -, foi criado um curso online, inicialmente utilizando a plataforma Youtube (com planos de expansão para plataformas de Massive Online Open Courses - MOOC's). O curso centrou-se em apresentar os pontos principais de atenção que foram percebidos pelo NEU ao longo de seu histórico com startups. Sua estrutura é de curta duração (em média, 5 a 10 minutos por vídeo), com ênfase em oferecer algo palatável para o universo digital - que geralmente não consome vídeos longos - e com riqueza de referências para aprofundamento, indicando textos, livros e outros conteúdos sobre a temática para estudo posterior. As aulas se dividiam em teórica e prática - sendo uma aula voltada para conteúdos teóricos e outra aula com um empreendedor da rede contando sua experiência com o tema. Para melhor compreensão do 
programa, indica-se visitar o portal do curso (NEU, 2016) de modo a conhecer melhor os conteúdos e, de suma importância, os materiais complementares. O curso assim se dividiu:

Tabela 4 - Organização das aulas e objetivos do curso online

\begin{tabular}{|c|c|}
\hline Título da aula & Objetivo e Conceitos \\
\hline $\begin{array}{l}\text { Aula } 1 \text { - Antes de } \\
\text { começar }\end{array}$ & $\begin{array}{c}\text { Apresentar as dificuldades iniciais de um empreendedor, preparar para a } \\
\text { necessidade de resiliência e foco e, principalmente, trazer realismo quanto } \\
\text { aos desafios de empreender. }\end{array}$ \\
\hline $\begin{array}{l}\text { Aula } 2 \text { - Imersão no } \\
\text { mercado }\end{array}$ & $\begin{array}{l}\text { Fazer com que o aluno absorva conceitos de avaliação de uma } \\
\text { oportunidade, envolvendo tamanho de mercado, competidores e dinâmicas } \\
\text { envolvidas na cadeia operacional. }\end{array}$ \\
\hline $\begin{array}{l}\text { Aula } 3 \text { - Modelos de } \\
\text { negócio }\end{array}$ & $\begin{array}{l}\text { Trazer atenção ao ferramental de modelagem de negócios e, mais } \\
\text { importante, destacar o conceito de 'ideias ruins que parecem ser boas' - } \\
\text { buscando evitar repetição de erros iniciais. }\end{array}$ \\
\hline Aula 4 - User obsession & $\begin{array}{c}\text { Direcionar os esforços do participante a conhecer a 'dor do usuário', } \\
\text { buscando - por meio de entrevistas - identificar os problemas vivenciados } \\
\text { e o comportamento do mesmo. }\end{array}$ \\
\hline $\begin{array}{l}\text { Aula } 5 \text { - Validação e } \\
\text { MVP }\end{array}$ & $\begin{array}{l}\text { Destacar a importância fundamental de ter uma mentalidade centrada em } \\
\text { aprendizagem que se utilize dos conceitos de MVP. Aplicação de método } \\
\text { científico para minimizar desperdícios iniciais. }\end{array}$ \\
\hline Aula 6 - How to pitch & $\begin{array}{c}\text { Ensinar a melhor estrutura para apresentar sua empresa para potenciais } \\
\text { interessados (investidores, clientes, parceiros e outros). }\end{array}$ \\
\hline $\begin{array}{l}\text { Aula } 7 \text { - Growth } \\
\text { Marketing }\end{array}$ & $\begin{array}{l}\text { Trazer reflexões sobre estratégias de marketing - especialmente no âmbito } \\
\text { da promoção - para empresas nascentes de base tecnológica, } \\
\text { caracterizadas pela escassez de recursos e excesso de riscos. }\end{array}$ \\
\hline Aula 8 - Growth Product & $\begin{array}{c}\text { Trazer compreensão sobre estágios de desenvolvimento de produto e } \\
\text { pontos importantes de experiência de usuário como fator de crescimento } \\
\text { da empresa. }\end{array}$ \\
\hline $\begin{array}{l}\text { Aula } 9 \text { - Cultura e } \\
\text { Operações }\end{array}$ & $\begin{array}{l}\text { Apresentar a importância da atenção aos aspectos culturais de uma } \\
\text { empresa nascente. Reforçar ferramental e conteúdos sobre } \\
\text { desenvolvimento de uma operação produtiva e motivante. }\end{array}$ \\
\hline $\begin{array}{l}\text { Aula } 10 \text { - Ecossistema e } \\
\text { Rede }\end{array}$ & $\begin{array}{l}\text { Apresentar os elementos de um ecossistema de empreendedorismo e } \\
\text { reforçar os esforços necessários para garantir o bom aproveitamento de } \\
\text { oportunidades por meio de uma rede de contatos. }\end{array}$ \\
\hline Aula 11 - Financiamento & $\begin{array}{l}\text { Destacar os mecanismos de financiamento de uma empresa em estágio } \\
\text { embrionário e os riscos envolvidos em modalidades diversas. }\end{array}$ \\
\hline $\begin{array}{l}\text { Aula } 12 \text { - Ganhando } \\
\text { experiência }\end{array}$ & $\begin{array}{c}\text { Por fim, enfatizar elementos ligados à experiência de desenvolvimento de } \\
\text { uma empresa nascente e principais erros. }\end{array}$ \\
\hline
\end{tabular}

FONTE: Elaborado pelo autor, baseado em NEU (2016).

(vi) Suporte em competições - O apoio dado em competições se mostrou uma maneira de aproveitar a motivação de alunos engajados em competições para capacitar e direcionar para a formalização do projeto de maneira a criar uma empresa. Aproveitando a criticidade e profundidade técnica dos alunos, o NEU se aprofundou em oferecer apoio relativo à estruturação do projeto, à modelagem do negócio (quando necessário) e, principalmente, à lógica de apresentação e argumentação. Tem-se tido êxito com tal ação, sendo um resultado importante a vitória de um grupo de alunos na competição de negócios 
do Prêmio Santander de Empreendedorismo (SANTANDER, 2016), cuja premiação era de $\mathrm{R} \$ 100.000,00$ e disputava-se com cerca de 20.000 outros projetos de todo o país. A vitória, além de sustentar a operação da empresa por um longo período garantindo um pleno amadurecimento do produto até tornar-se comercializável, ofereceu experiência em competições - gerando um mecanismo de retroalimentação, onde os vencedores e envolvidos sabiam os argumentos certos para ganhar outras competições, e assim auxiliaram outros projetos engajados a ganhar competições semelhantes.

(vii) Livro digital - Inicialmente pensado para ser somente o programa de aceleração redigido, de modo mais capilarizado e disseminável na orientação de alunos interessados em criar um negócio, o $E$-book $N E U$ se tornou um guia profundo de suporte aos alunos. $\mathrm{O}$ guia se voltou para a seguinte questão: 'sou um aluno da USP e quero empreender, o que faço?'. Desta maneira, ganhou detalhes ligados a organizações a procurar, ambientes interessantes, comportamentos e habilidades de empreendedores e, por fim, um passo-apasso sobre como desenvolver a ideia de negócio. O impacto do guia foi mais amplo do que o esperado, contando inclusive com centenas de downloads e disseminação via organismos formais, tais como os veículos de comunicação institucional da USP, professores e agentes da Pró-Reitoria de Pesquisa da Universidade.

\section{c) Conexão}

Por último, a conexão potencializa o impacto de projetos mais maduros, conectando empreendedores USP com novos mercados, possíveis parceiros, sócios, agentes de fomento e investidores. Tal mecanismo ocorre por meio de contato direto, eventos e parcerias realizadas com diversas instituições, como empresas juniores, aceleradoras de negócios e fundos de investimento. No modelo de Isenberg (2011), a conexão cobre os pontos relacionados ao contato com o mercado e, em alguns casos, o contato com instituições passíveis de fornecer financiamento. Algumas iniciativas pontuais se destinam especificamente a desenvolver a conexão:

(i) Open pitch: Em alguns eventos, abre-se, ao final, um espaço para alunos subirem ao palco e apresentarem, em um pitch de um minuto, suas ideias e projetos. A proposta é tornar visível a busca por clientes, parceiros, sócios e investidores. Geralmente apresenta resultados bastante interessantes e otimiza consideravelmente o poder do networking dos 
eventos, ocorrendo inclusive situações de contratação devido à conexão gerada através do open pitch.

(ii) Rede NEU: A proposta da rede é organizar, de maneira objetiva e bem estruturada, as conexões do núcleo. Para isso utiliza um grupo virtual que visa otimizar trocas de informações e aprofundamento de contatos, bem como é alocada uma pessoa para organizar esse grupo e mapear as pessoas participantes.

(iii) Vagas em startups: Por meio dos canais facebook, mailing e rede pessoal, a organização procura conectar startups para oferecer experiências de estágios aos alunos. Mais de 1000 alunos inscritos. O desenvolvimento desse projeto passou por diversos desafios, tais como membros ligados à execução do projeto sendo convidados para estagiar nas vagas que divulgavam e outras dificuldades comuns ligadas à tarefa de matchmaking (conexão entre dois players, também conhecida como marketplace). A estratégia que melhor gerou conversão foi a de os membros envolvidos na execução criarem suas próprias listas de alunos amigos reconhecidamente talentosos e fazer a conexão quase que manual desses membros. Espera-se, com os aprendizados ligados ao desenvolvimento manual, compreender mecanismos escaláveis de fazer tal conexão, tais como o uso de grupos no Facebook e posicionamento de um mailing interessante. Tal desenvolvimento manual faz parte de um dos pilares do ethos dos projetos, baseados no texto 'do things that don't scale' (GRAHAM, 2013), que reforça a importância de maximizar a aprendizagem em momentos iniciais de aquisição manual de clientes.

(iv) Conexão com agentes de mercado: alguns eventos são voltados para aproximar investidores e aceleradoras com startups USP, tais como a competição de ideias em parceria com a empresa júnior da FEA (FEA Jr.), onde os finalistas tiveram a oportunidade de apresentar suas ideias para investidores e aceleradoras. Um marco importante foi a aproximação com uma das principais aceleradoras da América Latina - Startup Farm onde foi possível fazer com que startups USP fossem aprovadas no processo seletivo da organização. Como um dos eventos de grande importância na história do NEU, das 4 primeiras colocadas no final do programa de aceleração, 3 eram startups formadas por alunos USP. Outras pontes diversas foram feitas ao longo da história do Núcleo - com investidores, potenciais clientes de grande porte, conexão entre startups nascentes e startups sólidas para contratação e aproximação com grandes empresas, como Porto Seguro (visita 
do Presidente da empresa para conhecer as startups), IBM (visita do CTO com o mesmo objetivo) e outras.

(v) Bate Papo da Rede NEU: Evento mensal, fechado para conectar startups nascentes com startups mais maduras e compartilhar desafios, absorvendo ferramentas, estratégias e contatos. No bate papo há uma troca mais profunda devido ao ambiente mais intimista e de colaboração, havendo inclusive resultados comerciais na conexão de projetos nascentes com empresas maduras. Tal estratégia foi percebida como rica no fortalecimento de laços e criação de uma atmosfera mais colaborativa entre a Rede, tendo sempre uma ênfase temática no encontro para nortear conteúdos, participantes e dúvidas.

Outros métodos de conexão, como a individual peer-to-peer ocorrem com frequência, mas sem formato determinado devido à sua particularidade em termos de ocorrência. Cabe o reforço do papel da Rede na articulação de parcerias e apoios, como uma das startups, a Nubank, trazendo a oportunidade de uma startup do NEU realizar um pitch para o Sequoia Capital, um dos principais fundos de investimentos do mundo (AGUILHAR, 2014).

\subsection{Levantamento de Experiências}

O levantamento de experiências se organizou, como apresentado na seção Metodologia, a partir de entrevistas semi-estruturadas realizadas com membros de movimentos estudantis grassroots voltados para empreendedorismo em Universidades brasileiras. O objetivo foi levantar - a partir de suas experiências vividas na fundação ou à frente da organização histórias, percepções e opiniões sobre o desenvolvimento de uma organização estudantil grassroots para empreendedorismo. As questões específicas distribuíram-se nos três blocos do seguinte modo:

Bloco 1 - O papel da universidade (e dos grassroots) na promoção do empreendedorismo: questões envolvendo (i) o papel da Universidade em ecossistemas; (ii) o papel do movimento grassroots em ecossistemas; (iii) no modelo de Lemos (2012), os papéis mais alinhados à organização.

Bloco 2 - A criação e desenvolvimento de uma organização grassroots para empreendedorismo em uma universidade: questões trazendo: (i) histórico da organização; (ii) atividades realizadas; (iii) resultados e métricas; (iv) desafios e soluções; (v) fatores críticos para a sobrevivência; (vi) desafios para o futuro; (vii) apoio da universidade sem 
tolhir a autonomia do movimento; (viii) relações com outras entidades e agentes do ecossistema; (ix) competências; (x) elemento liderança na história do movimento.

Bloco 3 - O modelo de maturidade proposto pela NACUE e sua aplicação aos casos estudados: questões para validar os elementos do modelo de maturidade NACUE, trazendo (a) a avaliação sobre o alinhamento do indicador ao contexto da organização e (b) autoavaliação da organização no indicador apresentado.

\subsubsection{Sobre as organizações}

(a) Núcleo de Empreendedores da FEA-RP: Entidade estudantil totalmente liderada por alunos e cujo estatuto é de 1997, o que a caracteriza como potencialmente a mais antiga das organizações grassroots para empreendedorismo no Brasil. Surgiu buscando apoiar pessoas da Universidade de São Paulo, campus Ribeirão Preto, na abertura da própria empresa centrando-se no uso do Plano de Negócios como ferramental de suporte. Inicialmente as operações eram bem-sucedidas, mas com o tempo perderam força e praticamente encerrando as operações do Núcleo. Em 2014, a aluna Bruna Toffoli assume a liderança da organização e junto com Pedro Henrique Alves resolvem redesenhar a organização. A entidade se destaca pelo relacionamento com o ecossistema e a rede de relacionamentos criada, envolvendo investidores, movimento empresarial, parque tecnológico da região (SUPERA) e relação com a comunidade.

(b) Centro de Empreendedorismo da UNIFEI: O Centro de Empreendedorismo da UNIFEI surgiu em 2012 e é encabeçado por alunos e professores, baseando no propósito de desenvolver comportamento empreendedor na Universidade por meio da execução de projetos - conceito originado da definição de um dos fundadores da organização, o professor Fabio Fowler, na qual o empreendedor é aquele que cria e gerencia projetos (FOWLER, 1997). Para a organização as empresas nascem como consequência do trabalho no comportamento dos alunos, podendo inclusive gerar fortalecimento no intraempreendedorismo dos atingidos. O Centro atua com três frentes: (i) educação empreendedora, que vem desde a origem da iniciativa, ligada a um curso de empreendedorismo ofertado - e que hoje permeia a grade dos cursos; (ii) comportamento empreendedor, centrando-se em formação complementar, semelhante a um minor, com disciplinas e projetos; (iii) desenvolvimento local e de startups, direcionando para a criação de empresas e geração de impacto na região. A força do movimento está no suporte a 
empresas de hard science (sic), voltadas para química, biotecnologia e outras originadas de pesquisas acadêmicas laboratoriais, e empresas de característica maker (sic), que trabalham com microeletrônica, robótica e tem forte apelo à construção de uma comunidade de interessados. Ambos os focos surgiram de maneira espontânea, com os alunos direcionando para essas áreas e destacando essa vocação da Universidade.

(c) Liga de Empreendedorismo da UNICAMP: A Liga surgiu em 2012 a partir de uma troca de e-mails entre três alunos de Engenharia que perceberam o movimento de outras entidades estudantis voltadas para empreendedorismo surgindo e decidiram formar uma na UNICAMP. Em 2014 passou por um redesenho e perdas de participantes, momento em que centrou-se em diminuir o número de áreas e organizar a operação em presidência (com foco em relacionamento na Universidade), diretoria executiva e membros. Operam com grande força em eventos, executando startup weekends (evento de caráter internacional para criação de startups), eventos de capacitação e treinamento, além de happy hours com empreendedores para fins de compartilhamento de experiências. São bastante conectados com os agentes regionais do ecossistema de Campinas, o que traz aprendizado e melhoria à organização.

\subsubsection{Análise do conteúdo}

Neste tópico, irão ser tratadas as falas apresentadas nas entrevistas de modo a captar a mensagem do entrevistado e expor de maneira coesa e organizada. A análise do conteúdo se baseou nos conceitos de Laurence Bardin, amplamente utilizado cientificamente, que apresenta o processo de análise dos conteúdos das mensagens visando realizar inferências de conhecimentos relativos ao contexto da mensagem analisada (CAREGNATO; MUTTI, 2006). Neste método, busca-se "compreender o pensamento do sujeito através do conteúdo expresso no texto, numa concepção transparente de linguagem" (CAREGNATO; MUTTI, 2006. p. 684). Para fins de tal ênfase proposta na análise do conteúdo, algumas palavras ou trechos são apresentados em sua totalidade - entre aspas - para reforçar a mensagem que o entrevistado buscou dar em sua fala. 


\subsubsection{Papéis a serem desempenhados}

(a) Núcleo de Empreendedores FEA RP: Segundo a fala dos entrevistados, USP Ribeirão Preto poderia desempenhar um forte papel relacionado ao seu ponto forte - o número de patentes geradas e pela profundidade do conhecimento nelas aplicado - especialmente na área médica (farmácia, odontologia e medicina). Porém, o caminho natural de tais projetos na USP Ribeirão Preto é ir para a USP Inovação (Escritório de Transferência de Tecnologia do campus) e "aposentar", nas palavras do entrevistado. Nesse ponto, o papel de desenvolvimento tecnológico singular da Universidade pode vir a ser complementado pelas competências ligadas à mercantilização da tecnologia que o Núcleo detém, tais como visão de mercado e aplicabilidade, negociação, vendas e administração. Ao Núcleo, cabe a tarefa de empoderar e capacitar os alunos interessados - e assim fazer com que os mesmos multipliquem o impacto por si, sendo a organização uma porta de entrada para um "ciclo empreendedor".

Há também uma necessidade percebida pelos entrevistados quanto ao suporte dado às entidades estudantis, sejam acadêmicas ou mais relacionadas ao mercado. Na percepção dos mesmos, tal esforço - em abertura, incentivo e até mesmo direcionamento de recursos públicos - pode vir a trazer o equilíbrio que falta entre teoria e prática na Universidade.

No modelo de Lemos, foi apontado que o Núcleo de Empreendedores da FEA-RP tem funções alinhadas a: conhecimentos e conexões; infraestrutura física; startups; agentes do ecossistema; governo; alunos; professores; portfólio de patentes; tecnologias; incubadoras; faculdade de administração; centro de empreendedorismo.

(b) Liga de Empreendedorismo da UNICAMP: A Universidade tem grande força no conhecimento dos professores, podendo ser um elemento relevante adicionando-os em redes do ecossistema para auxiliar o surgimento de empresas, além disso, disciplinas práticas tenderiam a gerar forte impacto - sendo um exemplo a disciplina que a UNICAMP oferece chamada launchpad com o Fábio Póvoa (um dos entrevistados a aponta como a melhor disciplina do curso). A Instituição também poderia ser mais apoiadora de movimentos, o que hoje não acontece, segundo as entrevistas. A oferta de infraestrutura para entidades e ter apoio da Pró-Reitoria de Graduação em eventos e ações poderia 
alavancar muito o potencial das entidades que se esforçam pelo incentivo do empreendedorismo na Universidade.

O papel da Liga se faz com grande ênfase em capacitação e empoderamento, como apontado também pelo Núcleo de Empreendedores da FEA-RP. A oferta de treinamentos com foco em ensinar metodologias ligadas à construção de soluções de problemas da região (reciclagem, mobilidade, segurança entre outros.), a realização de eventos ligados à criação de soluções práticas e o suporte motivacional no desenvolvimento das pessoas da Universidade são peças-chave para a organização.

No modelo de Lemos, foi apontado que a Liga de Empreendedorismo da UNICAMP tem maior alinhamento com: suporte aos alunos; desenvolvimento e relação com startups; articulação com agentes do ecossistema; relações com público alumni. Em certa medida, o elemento "capital, conhecimento e conexões" é coberto mais em conhecimento e conexões, sendo a liga um catalisador desses dois pontos.

(c) Centro de Empreendedorismo da UNIFEI: Para as entrevistadas, a Universidade tem papel especial na geração de tecnologia a partir do conhecimento gerado em seu ambiente. Nas palavras de uma entrevistada - "transbordar pesquisa em tecnologia, tecnologia em inovação, inovação em empreendedorismo". Cabe, portanto, a Universidade refletir sobre os potenciais papéis a serem desempenhados para tal objetivo - pensar e organizar a Universidade como um ecossistema para promoção do empreendedorismo. Há a atenção à necessidade da criação de formação complementar centrada em empreendedorismo, bem como o treinamento de professores para isso. Ir além da grade curricular é um passo importante que a Universidade Federal de Itajubá tem dado - sendo uma das menores Universidades Federais do país, mas contando com 40 projetos de extensão, sendo 10 deles ligados a competições de tecnologias com reconhecimento nacional e participação internacional (VELOSO, 2013). O apoio da Universidade a estes movimentos é considerado como fundamental para o incentivo ao empreendedorismo, inclusive o CEU é fruto de esforços que foram amplamente apoiados por gestões da Universidade que acreditavam no movimento e no papel do empreendedorismo como chave para uma instituição de pesquisa. Hoje a Universidade conta com um Diretor de Empreendedorismo para maximizar tal atenção dada. 
Quanto ao papel do movimento grassroots para empreendedorismo, é percebido no caso de Itajubá um forte resultado em termos de transbordamento regional. Nas palavras de uma das entrevistadas - "atuamos localmente, reverberamos regionalmente" -, afirmativa que reflete o papel desempenhado pelo Centro de Empreendedorismo da região, que chega a ter articulação até mesmo com a prefeitura da cidade devido ao positivo posicionamento galgado. O papel do CEU tem se mostrado bastante ligado à construção de comunidades, pensando sempre em ecossistemas e articulando suas operações de modo a gerar parcerias e maximizar o impacto a partir das interfaces. A transformação pode vir de diversas maneiras, tais como eventos como startup weekend, programas de ensino baseado em experiências reais e projeto de conexão para alunos estagiarem em startups. Nas entrevistas, a ênfase maior foi dada ao comportamental do movimento: pensar na criação de experiências únicas para os alunos; desconstruir vaidades que impedem a colaboração no ecossistema; operação enxuta e rápida; pensamento de abertura e transbordamento regional. É um trabalho de geração de novos multiplicadores - quando você impacta um aluno, ele se torna multiplicador da causa e do impacto no incentivo do empreendedorismo.

No modelo de Lemos, foram apontados os elementos: Centro de Empreendedorismo; apoio no desenvolvimento de startups; oferta de infraestrutura física; relação com agentes do ecossistema; relação com alunos; relação com professores; desenvolvimento de tecnologias a partir de pesquisa; papel de incubadora; relação com público alumni.

(d) Núcleo de Empreendedorismo da USP: A universidade pode desempenhar diversos papéis, tais como o trabalho mais direcionado para que o aluno veja empreendedorismo como uma carreira - comportamento percebido como não muito presente no caso da USP. O uso da infraestrutura aliada aos movimentos espontâneos para gerar tal engajamento é chave nessa transformação, segundo os entrevistados. Aproveitar a grande disponibilidade de espaços para incentivar a criação de "inovalabs" em diversas escolas - não somente na engenharia -, utilizando incentivo aos movimentos para trazer força e atmosfera vibrante para empreendedorismo nesses ambientes é algo transformador. O conhecimento também deve ser bem canalizado - tanto na formação de mão-de-obra qualificada para atuar em empresas nascentes, quanto na criação de formação aplicada em empreendedorismo - além do papel que a pesquisa acadêmica pode gerar em termos de uma inovação com uso mais intensivo do conhecimento. Um último ponto apresentado nas entrevistas foi a força que a universidade, especialmente a USP, tem na articulação com diversos setores da indústria, 
podendo oferecer redes de contatos e aproximar grandes empresas de potenciais projetos tecnológicos nascentes.

Segundo os entrevistados, o que tange ao papel de uma organização grassroots é o ato de preencher gaps não cobertos pela universidade em um ecossistema de empreendedorismo, e assim reforçar a relevância e o impacto da questão para a instituição. No caso da Universidade de São Paulo, um dos entrevistados aponta que o NEU criou um interessante motor de incentivo a isso: os pilares inspiração, capacitação e conexão. Com eles funcionando, definiu-se a forma de atuação e, a partir daí, foi preciso ser trabalhado o posicionamento do movimento grassroots, não somente se apresentando como um grupo de alunos buscando aprender ("fugindo dessa categorização de alunos" nas palavras do entrevistado), mas sim se mostrando como um grupo que gera real impacto na Universidade. O papel de articulador entre aluno e universidade é um papel relevante para um organismo grassroots, sendo uma peça fundamental na atuação com o ecossistema. Também foi reforçada a necessidade de realmente auxiliar a criação de empresas nascentes, e não somente se manter no campo inspiracional - palestras são interessantes, mas não se mostram com tanto resultado como a criação real de empresas. A atenção a resultados foi colocado como um diferencial do Núcleo no cumprimento dos seus papéis, pois os resultados trouxeram o apoio institucional necessário e alunos muito talentosos dispostos a fazer crescer a organização.

No modelo de Lemos, os entrevistados afirmaram forte alinhamento do Núcleo de Empreendedorismo da USP com as atividades: oferta de capital, conhecimento e conexões; atuação com startups; infraestrutura física; relação com agentes do ecossistema; relação com alunos; relação com professores; aproximação com a Faculdade de Administração; centro de empreendedorismo; relação com público alumni; relação com empresas estabelecidas; relação com parceiros e fornecedores.

\subsubsection{Criação e evolução do movimento grassroots}

(a) Núcleo de Empreendedores da FEA-RP: O Núcleo foi criado em 1997 quando o professor Alberto Mathias começou a identificar que os alunos de Ribeirão Preto tinham forte interesse em criar suas próprias empresas. Como a cidade se encontra muito longe de 
SP, há menos oportunidades em grandes empresas e mais oportunidades de mercado a se explorar empreendendo. Entre 1998 e 2001, uma aluna - Marisa, foi a primeira presidente e oficializou a criação do Núcleo. A partir daí, nasceu um braço de projetos sociais, o PICE (Programa Integrado de Capacitação Empreendedora), que oferece capacitação de microempresários de baixa renda e atinge 60 negócios por ano. Em 2000 foi criado o Empreender, evento para ajudar alunos na criação de suas empresas. O Núcleo de Empreendedores oferece também infraestrutura de coworking para desenvolvimento de startups, possuindo parceria com uma rede de empreendedorismo local e realizando eventos diversos (cursos, workshops e afins), além de executar a Semana Global de Empreendedorismo da região. Dois projetos nascentes são o Infinitos Kill the Box (apresentação das infinitas possibilidades fora da caixa para um aluno) e um Laboratório de Startups, que atuará em um formato de pré-aceleração. Ainda não se tem muitas métricas para mensurar o impacto, mas alguns números já mapeados são os do PICE (anualmente 40 atingidos no PICE Jovens e 20 no PICE). Os eventos atingem cerca de 50 pessoas por dia de realização.

Os principais desafios apresentados estão relacionados à gestão de pessoas e à infraestrutura do Núcleo. Na gestão de pessoas, foram apresentados: (i) o desafio de "disputar" os alunos com outras entidades - havendo uma pressão cultural sobre os alunos para se engajarem em alguma entidade e gerando muita disputa entre as entidades para captação de alunos; (ii) as dificuldades relativas ao engajamento voluntário, que gera alta rotatividade e necessidade de esforços para trazer mais sentido às atividades e obrigações; (iii) consequente dos problemas de engajamento, a complexidade da gestão do conhecimento e os medos relativos à perenidade da organização em casos de sucessão. Têm sido realizados esforços para dinamizar as atividades da organização, tais como criação de um campeonato interno de ideias, organização de grupos de estudo, atração de talentos multidisciplinares e outras. Quanto à infraestrutura, há um ponto ligado às dependências físicas e laboratoriais, porém, o mais presente na mensagem dos entrevistados se deu quanto ao fator financeiro. Há destacado desconforto no que tange à limitação de recursos financeiros do Núcleo, que hoje só consegue captar em eventos e com alguns pequenos patrocínios, o que deixa o caixa da organização em situação bastante frágil.

Nas relações externas ao Núcleo, há uma percepção de apoio por parte da Faculdade de Economia, Administração e Contabilidade da USP Ribeirão Preto. Há também um interesse 
em um apoio maior por parte da USP Ribeirão Preto de uma maneira geral, e interesse específico na articulação com a Agência de Inovação do campus - "poderíamos atuar junto com a Agência USP de Inovação para ajudar a transformar os projetos em negócios". Uma maneira de garantir apoio ao Núcleo sem tolhir a autonomia do movimento seria deixar claras algumas garantias e proteções no estatuto, de modo a evitar problemas ligados a interesses institucionais da Universidade conflitantes com interesses da organização. Com outras entidades, há uma separação relevante, especialmente na FEA-RP, ocorrendo um histórico de pouca colaboração e alinhamento. Contudo, os esforços para minimizar tal problema acontecem e, inclusive, se materializaram na Semana Global de Empreendedorismo organizada colaborativamente por 4 entidades. Há também a percepção de que um laboratório de startups, por seu caráter interdisciplinar e abrangente, poderia ser um elemento de maior aproximação de entidades da USP Ribeirão Preto como um todo.

Fora da Universidade, há uma forte relação com o Mover - Movimento Empreende Ribeirão, organização sem fins lucrativos composta por empresários da região que buscam desenvolver o ecossistema de empreendedorismo da cidade (VIAEPTV, 2014), fato que traz articulação com diversos agentes do ecossistema e catalisa os esforços do Núcleo. Além da relação com o Mover, existem parcerias com algumas empresas da região, com a Fundação Estudar e com o Parque Tecnológico Supera - sendo que há intercâmbio de membros do Núcleo estagiando no Parque e maximizando sinergias.

No que tange às competências esperadas por membros da organização, a atitude empreendedora é a mais forte - envolvendo proatividade, criatividade, liderança e com cultura de execução. Em uma das entrevistas foi destacado três princípios que a gestão do Núcleo gosta de ver nas pessoas: "ver o que ninguém vê, ser capaz de fazer acontecer e ter coragem para viver isso". Há também o papel fundamental de uma liderança na sobrevivência da organização - Bruna Toffoli, que assumiu o Núcleo quando estava "à beira da falência" e organizou recursos para sua reestruturação com novos membros. Sua postura garantiu a continuidade dos trabalhos e, a partir daí, a organização se consolidou com um projeto claro de gestão que atraiu novos membros e fortaleceu o engajamento com o Núcleo de Empreendedores da FEA-RP.

(b) Liga de Empreendedorismo da UNICAMP: Como apresentado no elemento introdutório, a Liga de Empreendedorismo foi criada a partir de uma troca de e-mails entre 
três alunos de engenharia que perceberam a necessidade de um centro focado em empreendedorismo na UNICAMP. A Liga gira em torno dos pilares (i) estímulo, (ii) capacitação e (iii) conexão e as atividades se desdobram principalmente nos eventos (startup weekends, capacitação, treinamentos e happy hours). Como métricas e elementos de validação tem-se: qualitativamente, ser referência para a Fundação Estudar; número de pessoas estimuladas e impactadas (variando de acordo com os eventos); percentual de membros antigos da Liga empreendendo - hoje é de aproximadamente 50\%. No começo do ano, é feito um plano no qual a Liga se atenta também a ter um número mínimo de ações para todos os pilares (estímulo, capacitação e conexão).

O maior desafio apresentado nas entrevistas foi o de gestão de pessoas. Em um determinado momento da operação, houve uma sobrecarga de atividades sobre os membros, e isso gerou um grande movimento de perda de membros - fator que chegou a prejudicar a execução de eventos por saída repentina de envolvidos. Tal desafio gerou o congelamento de alguns projetos e houve também transtornos operacionais, porém estimulou uma reorganização da Liga de Empreendedorismo. A partir dessa dificuldade, o número menor de membros trouxe maior alinhamento, redesenho da estrutura organizacional (sem áreas, norteada a projetos) e estimulou a criação de atividades internas de engajamento e motivação. Com o time mais enxuto e coeso, as atividades melhoraram e desenvolveu-se um esforço para que o membro percebesse crescimento dentro da organização - impactando positivamente no trabalho da Liga. Um dos fatores críticos para o sucesso foi a relação com a rede alumni - que, já no doutorado, voltaram à Liga de Empreendedorismo para ajudar o reerguimento e deram apoio fundamental, especialmente no fator liderança, que estímulo e direcionamento para os membros. O horizonte de desafios agora é fortalecer o posicionamento da Liga, realizando atividades com a bandeira da organização (não mais com parceiros que possam eclipsar a marca) e possuindo casos de sucesso real - envolvendo ganhos financeiros, não somente aparição na mídia, nas palavras do entrevistado - saídos da organização.

Quanto ao envolvimento institucional da UNICAMP sem que a autonomia do movimento grassroot seja tolhida, foram levantados dois pontos: burocracia e infraestrutura. $\mathrm{O}$ processo burocrático envolvido para se realizar eventos, atividades e disciplinas mostra-se muitas vezes impeditivo pela demora que gera e o nível de barreiras encontradas. Quanto à infraestrutura, há a reclamação de altos custos de realização de atividades, como, em um 
exemplo citado por um entrevistado, a cobrança de $\mathrm{R} \$ 10.000,00$ para a utilização de um auditório, fator que impediu a realização da atividade.

As relações são apontadas como um forte diferencial. Dentro da Universidade, há um contato até mesmo informal com o movimento de Empresas Juniores pelo fato de membros das entidades dividirem repúblicas juntos, o que catalisa as relações, mas tal fator também gera o risco de perda de parcerias nas mudanças de gestão - sendo a transição apontada como um desafio, pois os relacionamentos se mostram mais pessoais e menos institucionais. Há saudável troca de contatos e apoios em divulgação com outras empresas juniores, Enactus (movimento grassroots para empreendedorismo social) e MTE (Mercado de Trabalho em Engenharia, também organização estudantil grassroots). Externamente, há uma reforçada articulação com o ecossistema de empreendedorismo de Campinas, um dos mais bem articulados do país (EWERS, 2015): possuindo relações com Baita Aceleradora, Inova UNICAMP, UNICAMP Ventures, Fundação Estudar, Syhus Contabilidade e Startando.

Quanto às competências esperadas pela organização, foi dado destaque ao engajamento e disponibilidade. Mesmo tentando criar alguns mecanismos para membros com pouca disponibilidade, o modelo não funcionou - sendo hoje fator essencial estar engajado e disponível. O número de membros é limitado para a formação de um time alinhado e sólido quanto às competências. No fator liderança, três nomes foram apontados como elementares para a história da Liga de Empreendedorismo da UNICAMP - Mateus Borges, fundador e ex-presidente do Núcleo; Reginaldo Neto, hoje no MIT, fez parte da fundação, possui bastante prêmios de inovação e trouxe forte experiência e conhecimento à organização; Luiz Eduardo Ribeiro, que retornou à organização no momento de perdas de membros para orientar e dar direcionamento.

(c) Centro de Empreendedorismo da UNIFEI: O CEU nasceu em 2012 com a seguinte missão: formar empreendedores a partir de uma perspectiva de ensino transversal de empreendedorismo, em todas as áreas e se estruturando em modelos de ensino vivencial. Hoje, desempenha diversas atividades nesse sentido, dividindo-se em pesquisa, ensino e extensão tendo sido destacados durante a entrevista os seguintes: 
(i) Maio empreendedor - um mês de atividades centradas no tema para atrair atenção de alunos e gerar uma atmosfera vibrante;

(ii) Startup weekend e hackathon hacklab - eventos de mobilização e criação de novas soluções em um final de semana;

(iii) Startup bus e programa de estágio em startups - atividades de aproximação dos alunos com elementos do ecossistema;

(iv) TEDx e eventos/palestras inspiracionais;

(v) Bota pra fazer - incentivo ao empreendedorismo social;

(vi) Estímulo ao ensino de empreendedorismo - ações ligadas à oferta de formação complementar, formação de professores e influência na criação de novas disciplinas;

(vii) Programa de pré-aceleração de startups.

Ao serem perguntadas sobre resultados e métricas, as entrevistadas destacaram que as métricas se mostram mais como qualitativas, mas alguns números são importantes, tais como a criação de 15 a 20 grandes projetos de empreendedorismo na Universidade, quase 2000 mil alunos engajados (o que representa um terço do corpo discente, startups com relativo sucesso saindo do programa de pré-aceleração (agrosmart e awebic) e Bota pra Fazer gerando 50 a 70 projetos sociais ( 5 a 10 continuando a atuar na região depois do programa).

Houveram desafios no surgimento do Centro ligados à necessidade de um espaço dentro da Universidade e torná-lo apto para criar uma atmosfera vibrante e inovadora em um ambiente culturalmente engessado. A solução encontrada foi a conscientização por parte dos gestores da Universidade quanto à necessidade de desburocratizar - não institucionalizando o CEU e permitir liberdade para ousadia, experimentação e inventividade. O relativo isolamento da cidade de Itajubá em relação aos grandes centros econômicos também se mostrou um entrave, até mesmo na atração de apoio governamental e de grandes empresas - trazendo maior necessidade de "fazer mais barulho" para atingir objetivos e atrair olhares, nas palavras de uma das entrevistadas. Os fatores que garantiram a sobrevivência em meio aos desafios, segundo as entrevistas, foram a capacidade de formar empreendedores e engajar pessoas que realmente acreditam no empreendedorismo traços que refletiram na resiliência e capacidade de geração de saídas criativas e alinhadas à missão original do Centro de Empreendedorismo. Para o futuro, entende-se que a solidez 
alcançada fortalece o senso de missão e traz maiores ambições: o Centro apresenta forte interesse em auxiliar na geração de $\operatorname{spin-offs,~fortalecer~a~atuação~da~UNIFEI~na~}$ transferência de tecnologias geradas na pesquisa e trazer mais integração com a indústria. Há um sonho de ser um grande case na educação e, a partir disso, impactar o país como um todo. Nesse sonho, as entrevistadas demonstraram o desejo de que todo aluno da UNIFEI passe por projetos de empreendedorismo na graduação através de, no mínimo, uma disciplina obrigatória de empreendedorismo por curso.

No campo das relações, a atuação em conjunto com a Universidade sem que se tolha a autonomia se dá a partir de um voto de confiança às atividades do Centro, sendo este fundamentado em bastante diálogo de mão dupla e uma visão compartilhada de que o empreendedorismo realmente é fundamental para uma Universidade de pesquisa gerar impacto positivo no ecossistema em que se insere. Segundo uma das entrevistadas, núcleos grassroots precisam de sua autonomia e a Universidade precisa compreender seu modo diferenciado de proporcionar experiências e aprendizagem. Se baseando nessas premissas, a Universidade pode auxiliar por meio de oferta de infraestrutura física, aproximação com professores, indústria e governo, direcionamento de verba para ações, redes de contato e oferecimento de um fundo para pesquisa em empreendedorismo. É necessário que a Universidade compreenda que empreendedorismo gera resultados positivos e riqueza em um ciclo virtuoso - e que as ações de uma organização grassroots auxiliam muito nesse sentido.

Foi demonstrada também ótima relação com as outras entidades da UNIFEI, tendo sido a reitoria um elemento de abertura de portas nas relações com outras organizações, institutos e coordenadorias de curso (o CEU foi apresentado para todas as coordenações de ensino). Há boa relação com as empresas juniores e centros acadêmicos, inclusive com auxílio na complementariedade técnica quando necessária em projetos de outras entidades que demandam expertises específicas do Centro (temas relacionados a empreendedorismo, criatividade e inovação) - fator que gera bastante colaboração. A prioridade, no entanto, são as relações externas - incubadora, rede de mentores, empreendedores, startups (muitas saídas do CEU ou da UNIFEI que passam a colaborar com a organização) e outras universidades da região (Santa Rita do Sapucaí, Pouso Alegre, Poços de Caldas, Varginha, Alfenas, Lorena entre outras). O SEBRAE é uma grande parceria externa, que apoia em eventos e projetos diversos. 
Para as competências exigidas, as respostas penderam para fatores comportamentais de engajamento: "cara de pau"; "amor à causa"; ser direcionada por projetos; ter alta performance; sólido senso de urgência; horário flexível; iniciativa; por fim, ter capacidade de autogerenciamento devido ao caráter horizontal da organização. Duas lideranças foram citadas como marcantes na história da organização e demonstram a positiva influência gerada quando a universidade colabora com os movimentos: o professor Fabio Fowler, um dos principais idealizadores do Centro e renomado por ser o maior advogado da causa (Diretor de Empreendedorismo da UNIFEI) e o ex-reitor Renato Nunes, responsável pela abertura de portas assumida pela Universidade no suporte e incentivo ao desenvolvimento da organização.

(d) Núcleo de Empreendedorismo da USP: A mensagem dos entrevistadores é reforçado por um forte senso de propósito, podendo ser percebido reconhecimento aos esforços e missão apresentada, trazendo pontos como "mudar o mundo de uma forma significativa" e como o sacrifício dos fundadores que abriam mão de oportunidades de emprego/empreendimento para se dedicar à construção da organização. O NEU surge, portanto, com seu propósito norteado à missão de suprir um gap percebido na USP - o estímulo ao empreendedorismo gerando impacto real, mostrando como possibilidade concreta para um aluno e dando o suporte necessário para seu avanço nesse sentido. Atualmente, as atividades do núcleo se dividem entre atividades core (baseadas nos pilares inspiração, capacitação e conexão - com os projetos destrinchados no relato descritivo) e atividades de suporte (comunicação, relação de parcerias, imagem institucional entre outras). Em termos de métricas, o Núcleo ainda carece de mensuração quantitativa profunda, mas qualitativamente há uma percepção de crescimento no posicionamento, de formalização na mentalidade de startup para a operação (que trouxe produtividade e engajamento) e de atenção positiva das autoridades da Universidade para o movimento. Alguns números são mapeados, tais como eventos atingindo a casa dos milhares de ingressos vendidos, 15 startups sendo constantemente desenvolvidas no programa de préaceleração (com startups originadas do programa já destacadas no mercado) e mais de 1000 alunos inscritos no programa de conexão para estagiar em startups. Os entrevistados apontam alguns horizontes de métricas que poderiam ser avaliadas: número de startups; número de pessoas impactadas; número de pessoas que vão trabalhar em startups; número de membros; rotatividade de membros; posicionamento nos números das redes sociais. 
Contudo, já houveram tentativas de acompanhamento que não funcionaram, sendo um desafio à organização.

Aprofundando nos desafios encontrados, o elemento gestão de pessoas no crescimento também foi destacado nessa organização. A alta rotatividade de membros e os problemas de engajamento geraram momentos de instabilidade no Núcleo de Empreendedorismo da USP, inclusive desdobrando-se em problemas de gerenciamento de projetos e super-alocação. Um dos entrevistados apontou que pelo fato de o nível exigido de entrega ao Núcleo ser muito alto, eleva-se o risco de membros perdendo o engajamento. Para tal limitação, o reforço no senso de propósito e a clareza quanto às atividades e projetos core da operação foram fundamentais, pois trouxeram maior motivação e alinhamento de expectativas. Um outro elemento apontado era a limitação financeira, especialmente individual de cada membro. Por ser um trabalho voluntário, a atuação na organização muitas vezes é prejudicada por necessidades pessoais financeiras - nesse caso, a solução encontrada foi a busca por bolsas paralelas (iniciação científica, bolsa da Agência USP de Inovação e afins) para conseguir manter uma atuação em conjunto sem prejudicar o Núcleo com a saída do membro.

Como fatores críticos para o sucesso da organização foram apontados: (i) capacidade de atrair, manter e desenvolver talentos; (ii) reputação por meio de pessoas íntegras, bons professores orientadores e entregas de alto nível; (iii) resultados e posicionamento capaz de engajar e gerar comprometimento nos membros; (iv) velocidade de entrega orientada ao propósito; (v) estabelecimento de boas relações com a Universidade, mercado e alunos. Sobre os desafios para o futuro do Núcleo, os entrevistados destacaram alguns desafios referentes ao crescimento que a organização tem vivenciado, tais como o de realizar uma transição de gestão de maneira sólida e atenta à cultura e dinâmica de entregas, o ganho de escala sem perder o controle das entregas nem da rede de contatos articulada pelo Núcleo e, por fim, o desafio de manter à frente do NEU lideranças "íntegras, bem intencionadas e competentes" para gerir os talentos em ascensão.

Quanto às interfaces, os entrevistados acreditam que a universidade pode apoiar sem tolhir a autonomia, como acontece no caso da USP. Havendo independência financeira e respeito por parte do movimento grassroots, a contrapartida esperada é que haja confiança por parte da universidade - avaliando, apoiando e confiando nas operações, não precisando de um 
aval institucional para se movimentar e nem havendo necessidade de processos que podem travar o dinamismo de uma operação com as características do Núcleo. Um dos entrevistados vivenciou um processo de engessamento em outra organização e destacou a necessidade de confiança plena no apoio oferecido (em forma de infraestrutura e outros recursos vitais). Nas palavras de um dos entrevistados: "enquanto continuar o bom trabalho, continua o apoio". As interfaces com outros organismos dentro da Universidade são apresentadas como um ponto forte do NEU, que é apresentado como rico em relacionamentos institucionais e de entidades, sendo bem posicionado, aberto e constantemente consultado por diversos agentes da USP quando o assunto é empreendedorismo. Há um bom posicionamento com agentes externos, porém, esse posicionamento foi apontado como ligado diretamente a indivíduos, não à organização fator que pode desencadear em problemas futuros com transição de gestão. Apesar do bom posicionamento, os entrevistados destacaram que há pouco contato direto e colaboração com esses agentes externos, justificados pelo fato de desalinhamento cultural entre a mentalidade do NEU e a percebida nos agentes de empreendedorismo da cidade de São Paulo. Um exemplo apresentado sobre o desalinho é o excesso de discussões e eventos do ecossistema paulistano que se distanciam do considerado efetivamente empreender, da cultura de execução defendida pelo Núcleo. Nas palavras de um dos entrevistados: "não temos muito interesse em perpetuar esse modus operandi do ecossistema - acreditamos ser prejudicial".

Ao relatar as competências necessárias, os membros entrevistados afirmaram que é esperada uma participação significativa em relação aos novos entrantes, apontando traços como proatividade, comprometimento, foco e integridade fundamentais. Além de tais competências, foi reforçada a necessidade de conhecimento elevado em empreendedorismo, havendo uma capacitação e estímulo ao estudo de conteúdos desde a entrada de um novo membro, garantindo um patamar alto de entregas. Quanto à existência de líderes que nortearam a história da organização, o nome do Artur Vilas Boas foi destacado em todas as entrevistas como a figura que sobreviveu aos problemas de rotatividade e pouco engajamento, se mantendo presente e garantindo a continuidade da operação e o fortalecimento das relações externas. Além disso, é colocado o fato de sua visão ter definido a forma de cultura e operação, a qualidade das entregas e as atividades desempenhadas. Segundo um dos entrevistados, "foi ele que não deixou morrer - e muito da cara da organização, de como ela trabalha e das coisas que ela se propõe a fazer foram 
desenhadas pela visão dessa pessoa". Além dessa figura, outros nomes como Rodrigo Fernandes (atuou ao lado do Artur no desenho das operações e nas relações externas), Maurício Carneiro (responsável pela estruturação da organização interna do NEU), Giovanna Trindade (atuando na comunicação e marketing da organização, dialogando não só com a Universidade, mas mantendo relações saudáveis com outros grassroots no brasil), Juliana Uechi (responsável pelos programas de desenvolvimento de startups) e Lucas Liupekevicius (responsável pela estruturação da organização de eventos, palestras e realizações que atingiram um grande número de pessoas).

\subsubsection{Validação do Modelo de Maturidade NACUE}

Como terceiro objetivo do estudo, buscou-se a validação de um Modelo de Maturidade criado para movimentos grassroots do Reino Unido ao ser aplicado em um contexto brasileiro. O Modelo de Maturidade NACUE (2012) se estrutura em 11 indicadores divididos em 3 pilares: estrutura da organização; gestão de relacionamentos; atividades e desenvolvimento. Em estrutura da organização, tem-se os indicadores (i) estratégia, (ii) governança, (iii) processos internos, (iv) sucessão e (v) assinatura. Em gestão de relacionamentos inserem-se os indicadores (vi) relações internas e (vii) relações externas. Por fim, atividades e desenvolvimento cobrem (viii) impacto gerado e negócios criados, (ix) portfólio de captação financeira, (x) marketing e branding e (xi) programação de atividades e eventos. No Reino Unido, ele é aplicado em dezenas de organizações filiadas à NACUE (National Association of College and University Entrepreneurs) de modo a gerar avaliações comparativas entre organizações e ao longo do tempo, gerando orientação e compartilhamento de melhores práticas. O uso de Modelos de Maturidade tem se fortalecido no contexto de ecossistemas de empreendedorismo (STANGLER e BELLMATERSON, 2015; CUKIER, KON e KRUEGER, 2015; COMPASS.CO, 2015) por oferecer uma maneira de avaliar distintos graus de ambientes e organizá-los em uma escala de maturidade para direcionamento e categorização mais específicos.

Para a aplicação, foram apresentados os indicadores e suas explicações de modo a orientar o respondente a avaliar o quão relevante é o indicador para sua organização - utilizando uma escala Likert de 5 pontos. Uma segunda pergunta complementar induzia o participante a fazer uma auto-avaliação de teor qualitativo sobre o nível de maturidade da própria organização - dados que serão utilizados apenas para uma breve observação, sem finalidade 
de ser aprofundado na presente dissertação para manter-se centrado no objetivo de somente validar o modelo, não avaliar as maturidades.

Cada indicador continha uma breve explicação, baseada no Modelo de Maturidade NACUE (2012), para esclarecer e evitar posicionamentos errados. As explicações se deram da seguinte maneira:

-Estratégia: desenvolvimento e execução de planos estratégicos de curto e médio prazo para crescimento sustentável;

-Governança: nível de profissionalismo na organização da estrutura de gestão e no corpo de conselheiros;

-Processos internos: efetividade organizacional, incluindo reuniões estruturadas, uso de plataformas para comunicação digital e o desenvolvimento de práticas operacionais;

-Sucessão: desenvolvimento e execução de um plano de sucessão e transição de gestão que garanta a sobrevivência e crescimento da organização a cada ano;

-Assinatura: número de assinantes registrados e associados à organização, bem como o desenvolvimento e execução de um plano de marketing para diversificação da base de assinantes

-Relações internas: força de comunicação e colaboração que a organização possui com o corpo-chave da universidade

-Relações externas: força na comunicação e colaboração que a organização possui com a comunidade local, com os negócios locais e nacionais e outras organizações regionais, nacionais e internacionais;

-Impacto gerado e negócios criados - desenvolvimento e execução de atividades que influenciam diretamente no suporte a empreendimentos ligados à organização, bem como à criação de novos negócios;

-Portfólio de captação financeira: quantidade de caixa e outros tipos de financiamento levantado, bem como a diversidade das fontes;

-Marketing e branding: desenvolvimento e execução de uma estratégia compreensiva e coerente de marketing e branding, de modo a aumentar o engajamento de alunos de maneira sustentável; 
-Programação de atividades e eventos - desenvolvimento e execução de uma série de atividades que ofereçam inspiração, capacitação, aprendizagem experiencial, networking e outras oportunidades para empreendedorismo.

Como tratamento dos dados, utilizou-se o conceito de moda - como já explicado na metodologia, buscando validar a relevância dos indicadores.

Tabela 5 - Tabulação de dados da escala Likert

\begin{tabular}{|l|l|l|l|l|l|l|l|l|c|}
\hline \multicolumn{1}{|c|}{ Indicador } & E1 & E2 & E3 & E4 & E6 & E8 & E9 & E10 & Moda \\
\hline Estratégia & 5 & 5 & 5 & 3 & 5 & 4 & 5 & 4 & $\mathbf{5}$ \\
\hline Governança & 5 & 3 & 4 & 4 & 4 & 5 & 4 & 4 & 4 \\
\hline Processos internos & 5 & 4 & 5 & 3 & 3 & 5 & 5 & 5 & $\mathbf{5}$ \\
\hline Sucessão & 5 & 5 & 5 & 2 & 5 & 4 & 4 & 4 & $\mathbf{5}$ \\
\hline Assinatura & 5 & 3 & 2 & 1 & 5 & 2 & 3 & 3 & $\mathbf{3}$ \\
\hline Relações internas & 5 & 5 & 5 & 4 & 4 & 5 & 4 & 2 & $\mathbf{5}$ \\
\hline Relações externas & 5 & 4 & 5 & 5 & 4 & 4 & 4 & 5 & $\mathbf{4 - 5}$ \\
\hline Impacto gerado e negócios criados & 5 & 5 & 5 & 5 & 5 & 5 & 3 & 5 & $\mathbf{5}$ \\
\hline Portfólio de captação financeira & 5 & 4 & 5 & 4 & 3 & 3 & 3 & 4 & $\mathbf{4 - 3}$ \\
\hline Marketing e branding & 5 & 2 & 5 & 5 & 3 & 5 & 4 & 3 & $\mathbf{5}$ \\
\hline Programação de atividades/eventos & 5 & 5 & 5 & 5 & 5 & 4 & 5 & 4 & $\mathbf{5}$ \\
\hline
\end{tabular}

FONTE: Elaborado pelo autor.

Conforme apresentado acima, há uma predominância da percepção de que os indicadores possuem alta relevância em termos de replicabilidade em um contexto nacional. Dois itens apresentam certo desvio acentuado - o conceito de assinatura e o elemento de captação financeira. Por serem operações ligadas a uma estrutura de trabalho voluntário e com recursos fornecidos pela universidade, os membros parecem dar menor importância a tais necessidades. Na questão de auto-avaliação para o indicador "Assinatura", a maioria dos entrevistados apontou que o não poderia avaliar pois não se aplica ao contexto de sua organização - demonstrando uma possível não adaptação do item à cultura das universidades brasileiras, que não possuem uma modalidade de afiliados que pagam uma quantia mensal ou anual para receber benefícios do órgão grassroots de empreendedorismo.

Como uma maneira de avaliar a distribuição das respostas e verificar a consistência do indicador, fez-se uma análise da distribuição da intensidade de cada nota por indicador, organizando os dados da seguinte maneira: 
Tabela 6 - Distribuição das notas da escala Likert

\begin{tabular}{|c|c|c|c|c|c|}
\hline Indicador & $\begin{array}{c}\text { Completamente } \\
\text { relevante }\end{array}$ & $\begin{array}{c}\text { Muito } \\
\text { relevante }\end{array}$ & Relevante & $\begin{array}{c}\text { Pouco } \\
\text { relevante }\end{array}$ & $\begin{array}{c}\text { Nada } \\
\text { relevante }\end{array}$ \\
\hline Estratégia & $63 \%$ & $25 \%$ & $13 \%$ & $0 \%$ & $0 \%$ \\
\hline Governança & $25 \%$ & $63 \%$ & $13 \%$ & $0 \%$ & $0 \%$ \\
\hline Processos internos & $63 \%$ & $13 \%$ & $25 \%$ & $0 \%$ & $0 \%$ \\
\hline Sucessão & $50 \%$ & $38 \%$ & $0 \%$ & $13 \%$ & $0 \%$ \\
\hline Assinatura & $25 \%$ & $0 \%$ & $38 \%$ & $25 \%$ & $13 \%$ \\
\hline Relações internas & $50 \%$ & $38 \%$ & $0 \%$ & $13 \%$ & $0 \%$ \\
\hline Relações externas & $50 \%$ & $50 \%$ & $0 \%$ & $0 \%$ & $0 \%$ \\
\hline $\begin{array}{c}\text { Impacto gerado e } \\
\text { negócios criados }\end{array}$ & $88 \%$ & $0 \%$ & $13 \%$ & $0 \%$ & $0 \%$ \\
\hline $\begin{array}{c}\text { Portfólio de captação } \\
\text { financeira }\end{array}$ & $25 \%$ & $38 \%$ & $38 \%$ & $0 \%$ & $0 \%$ \\
\hline Marketing e branding & $50 \%$ & $13 \%$ & $25 \%$ & $13 \%$ & $0 \%$ \\
\hline $\begin{array}{c}\text { Programação de } \\
\text { atividades/eventos }\end{array}$ & $75 \%$ & $25 \%$ & $0 \%$ & $0 \%$ & $0 \%$ \\
\hline
\end{tabular}

FONTE: Elaborado pelo autor.

$\mathrm{Na}$ distribuição das respostas, pode-se perceber uma maior concentração de respostas que trazem inconsistência ao item "Assinatura", sendo que o item "Portfólio de captação financeira" se mostrou mais consistente e equilibrado positivamente, eliminando uma possibilidade de desconsideração do item em um Modelo de Maturidade brasileiro. Os outros itens confirmaram sua consistência pela predominância de percepções positivas referentes à relevância dos indicadores.

Desta forma, pode-se afirmar que a utilização do Modelo de Maturidade NACUE, com a retirada do item "Assinatura", apresenta relativa consistência metodológica e poderia se mostrar válido em um contexto de organizações grassroots para empreendedorismo nas universidades de pesquisa brasileiras. 


\section{CONSIDERAÇÕES FINAIS}

Este capítulo tem como objetivo organizar os aprendizados de maneira coesa e condensada, de modo a guiar o leitor pelos aprendizados gerados pela pesquisa dos múltiplos casos e reforçar os principais conceitos que se mostraram como padrões ao longo da execução das entrevistas e do relato descritivo.

\subsection{Da prática à teoria: relações identificadas no referencial teórico}

Alguns elementos se mostraram bastante presentes nas entrevistas realizadas e demonstraram profunda relação da prática com a teoria. Tal fato ocorreu seja por inspiração por parte de líderes das organizações que se embasaram na teoria, seja pelo natural curso da produção teórica com boas raízes metodológicas - que fez com que os resultados obtidos demonstrassem idoneidade com os resultados obtidos por estudos similares, embora esta dissertação não tenha tido como objetivo a replicabilidade de tais experimentos.

Na realização da imersão teórica, diversos pontos tocaram no papel e nas competências das lideranças para desenvolvimento de ecossistemas de empreendedorismo. Para Brad Feld (2012), há um reforço no argumento de que ecossistemas são bem desenvolvidos quando liderados por empreendedores, cujas competências ligadas à habilidade de estabelecer compromissos de longo prazo e à habilidade de construir redes de apoio se mostram fundamentais. Outros elementos ligados à competência foram destacados por Kon et al (2014), ao apontar traços como paixão por fazer diferença, comunicação autêntica e nãohierárquica, predisposição ao risco e resiliência nos elementos culturais do desenvolvimento destas comunidades. Por fim, Etzkowitz (2013) acrescentou ao presente estudo a habilidade das lideranças de organizar recursos de modo a orientar o desenvolvimento do ecossistema em que estavam inseridas.

Tais elementos apresentaram-se tanto no levantamento de experiências quanto no relato descritivo - com informações apresentadas sobre (i) momentos nos quais a resiliência das lideranças manteve a operação funcionando em meio aos riscos e incertezas, garantindo a sobrevivência e o sucesso da organização; (ii) horizontalidade, habilidade de motivar e nortear os esforços por meio de paixão, além de uma cultura de operação enxuta e ágil; (iii) compromisso de longo prazo por parte de líderes - que muitas vezes voltaram à organização 
para auxiliar e dar suporte em momentos de crise. Neste tópico também dialogam os principais desafios apresentados pelas organizações: alta rotatividade, pessoalidade e gestão do conhecimento. Pelo fato de a vida estudantil ser aspecto central dessas organizações, construir uma operação com tais características em paralelo às atividades ligadas à formação dos alunos se mostra um profundo desafio a ser resolvido. Algumas organizações apresentaram soluções com estratégias de governança melhor estruturada, atenção constante à transição de gestão e capacitação de membros e elementos sólidos de gestão do conhecimento para ambientes de grande rotatividade.

Um outro elemento no qual a teoria dialoga com a prática é a importância de uma visão orientada a ecossistemas, como proposto por Lemos (2012). Uma análise aprofundada dos papéis apresentados por cada organização no modelo de Lemos pode trazer melhores perspectivas sobre sinergias no direcionamento de uma universidade de pesquisa para um papel efetivo no incentivo ao empreendedorismo. Houve uma marcante repetição de mensagens na análise do conteúdo que destacaram o interesse das organizações grassroots em participar em conjunto com Escritórios de Transferência de Tecnologia para um trabalho mais intensivo com projetos ligados à pesquisa. Tal interesse por parte de organizações autônomas, que, portanto, não representam custo excessivo para a universidade, pode ser uma maneira de potencializar resultados e otimizar a utilização de recursos. Além deste tópico ligado ao modelo de Lemos, foi percebido que a vinculação das atividades dos movimentos grassroots com outros elementos do ecossistema - rede de alumni, laboratórios, parceiros externos e afins - se mostrou bastante poderosa em termos de sinergia, sendo um exemplo a relação do Núcleo de Empreendedorismo da USP com o Inovalab da Poli. Um terceiro ponto ligado à visão orientada a ecossistemas é a compreensão dos spillovers de Isenberg (2011) - os feedbacks positivos que naturalmente acontecem quando uma organização começa a se movimentar, tais como a atração de outras iniciativas, o envolvimento de outras instituições, a aceitação por parte dos governantes (no caso das universidades, por parte do corpo diretor) e a tração espontânea gerada pelo estímulo a uma cultura de empreendedorismo, todos pontos presentes nos relatos levantados. Um dos feedbacks positivos percebidos foi o fato de uma startup inicialmente apoiada pelo NEU no início das operações, a Nubank, sendo patrocinadora e conectora em outros eventos, conforme apontado em notícias apresentadas pelo relato.

Finalizando o compilado de relações identificadas entre teoria e prática, temos o estudo dos 
movimentos grassroots. Goldberg e Somerville (2012), bem como Maeda (2016), destacam o potencial de movimentos estudantis na identificação de tendências e novas maneiras de resolver problemas antigos, característica presente em muitos relatos levantados quanto ao histórico de criação das organizações - a percepção de um gap sobre o qual percebiam que a universidade não estava resolvendo da melhor maneira. Considerou importante para o presente capítulo trazer a listagem das abordagens grassroots no ensino superior (KEZAR, GALLANT e LESTER, 2011) de modo a fazer um comparativo com o percebido nos relatos:

Tabela 7 - Relação entre base teórica e dados levantados

\begin{tabular}{|c|c|c|}
\hline & $\begin{array}{l}\text { Elementos teóricos } \\
\text { sobre grassroots }\end{array}$ & Contexto prático dos casos \\
\hline Inspiração e Liderança & $\begin{array}{c}\text { Força orientada por uma } \\
\text { visão }\end{array}$ & $\begin{array}{l}\text { Sobrevivência baseada em uma visão } \\
\text { maior e no papel das lideranças }\end{array}$ \\
\hline $\begin{array}{l}\text { Abordagem para } \\
\text { influência em ensino, } \\
\text { pesquisa e serviços }\end{array}$ & $\begin{array}{l}\text { Esforços e ações } \\
\text { centradas no aumento de } \\
\text { consciência coletiva }\end{array}$ & $\begin{array}{l}\text { Esforços e ações centradas em } \\
\text { conscientização coletiva, além do uso } \\
\text { de redes de relacionamentos } \\
\text { estratégicos. }\end{array}$ \\
\hline $\begin{array}{l}\text { Processos de } \\
\text { fortalecimento e } \\
\text { posicionamento da } \\
\text { organização }\end{array}$ & $\begin{array}{l}\text { Criação de redes de } \\
\text { contatos / } \\
\text { empoderamento de } \\
\text { outros líderes / } \\
\text { construção de } \\
\text { relacionamentos }\end{array}$ & $\begin{array}{l}\text { Ênfase nas redes de contatos e } \\
\text { relacionamentos estratégicos. Uso de } \\
\text { redes sociais como elemento-chave } \\
\text { para posicionamento e alcance. }\end{array}$ \\
\hline $\begin{array}{l}\text { Construção de cultura e } \\
\text { governança }\end{array}$ & Mobilização de pessoas & $\begin{array}{l}\text { Mobilização de pessoas e uso de } \\
\text { processos claros orientando. }\end{array}$ \\
\hline $\begin{array}{l}\text { Mecanismos de garantia } \\
\text { de recursos }\end{array}$ & $\begin{array}{l}\text { Acúmulo orgânico de } \\
\text { recursos }\end{array}$ & $\begin{array}{l}\text { Acúmulo orgânico e aquisição de } \\
\text { recursos externos via patrocínio, bolsas } \\
\text { e parcerias. }\end{array}$ \\
\hline $\begin{array}{l}\text { Expansão e influência } \\
\text { externa }\end{array}$ & $\begin{array}{l}\text { Uso de persuasão e } \\
\text { influência }\end{array}$ & $\begin{array}{c}\text { Influência por meio de mídias digitais e } \\
\text { parcerias com agentes regionais e } \\
\text { governamentais. }\end{array}$ \\
\hline
\end{tabular}

FONTE: Elaborada a partir de Kezar, Gallant e Lester (2011)

\subsection{Estrutura de atividades e métricas das organizações}

Para fins de melhor organização e apresentação visual, preferiu-se organizar as atividades e métricas quantitavas das organizações em uma tabela resumida e distribuída pelos pilares de ação percebidos nos casos estudados. Tanto as atividades quanto as métricas foram apresentadas na análise do conteúdo ou no relato descritivo. 
Tabela 8 - Atividades e potenciais métricas quantitativas

\begin{tabular}{|c|c|c|c|}
\hline & Inspiração/estímulo & Capacitação/ensino & Conexão/estrutura \\
\hline $\begin{array}{c}\text { Núcleo de } \\
\text { Empreendedorismo } \\
\text { da USP }\end{array}$ & $\begin{array}{l}\text { Palestras; } \\
\text { Almoço com } \\
\text { empreendedor; } \\
\text { Conteúdo inspiracional; } \\
\text { Interface com sala de } \\
\text { aula. }\end{array}$ & $\begin{array}{l}\text { Levantamento de } \\
\text { disciplinas ligadas a } \\
\text { empreendedorismo; } \\
\text { Pré-aceleração; } \\
\text { Cursos e workshops; } \\
\text { Parcerias com apoio } \\
\text { financeiro aos alunos; } \\
\text { Vídeo-aulas; } \\
\text { Suporte em } \\
\text { competições; } \\
\text { Livro digital. }\end{array}$ & $\begin{array}{l}\text { Rede NEU - grupo } \\
\text { virtual com toda a rede } \\
\text { de contatos; } \\
\text { Open Pitch para a } \\
\text { Rede; } \\
\text { Conexão para vagas } \\
\text { em startups; } \\
\text { Conexão com agentes } \\
\text { do mercado; } \\
\text { Bate papo da Rede; } \\
\text { Coworking. }\end{array}$ \\
\hline $\begin{array}{c}\text { Centro de } \\
\text { Empreendedorismo } \\
\text { da UNIFEI }\end{array}$ & $\begin{array}{l}\text { Maio empreendedor } \\
\text { (atrair atenção de } \\
\text { alunos); } \\
\text { Startup Weekend; } \\
\text { Hackathons; } \\
\text { TEDx; } \\
\text { Palestras. }\end{array}$ & $\begin{array}{l}\text { Bota pra Fazer; } \\
\text { Estímulo ao ensino de } \\
\text { empreendedorismo; } \\
\text { Pré-aceleração; } \\
\text { Coworking. }\end{array}$ & $\begin{array}{l}\text { Startup bus - visita a } \\
\text { startups; } \\
\text { Programa de estágio } \\
\text { em startups; } \\
\text { Coworking. }\end{array}$ \\
\hline $\begin{array}{c}\text { Núcleo de } \\
\text { Empreendedores da } \\
\text { FEA/RP }\end{array}$ & $\begin{array}{l}\text { Semana Global de } \\
\text { Empreendedorismo; } \\
\text { Apresentação de } \\
\text { possibilidades para } \\
\text { alunos; } \\
\text { Eventos de inspiração; }\end{array}$ & $\begin{array}{l}\text { Capacitação regional } \\
\text { para baixa renda; } \\
\text { Pré-aceleração; } \\
\text { Treinamentos e cursos } \\
\text { para alunos. }\end{array}$ & $\begin{array}{l}\text { Coworking; } \\
\text { Rede de } \\
\text { Empreendedores } \\
\text { Locais; }\end{array}$ \\
\hline $\begin{array}{c}\text { Liga de } \\
\text { Empreendedorismo } \\
\text { da Unicamp }\end{array}$ & $\begin{array}{l}\text { Eventos de inspiração e } \\
\text { motivação; } \\
\text { Startup Weekend. }\end{array}$ & $\begin{array}{l}\text { Treinamentos em } \\
\text { metodologias; } \\
\text { Capacitação em } \\
\text { empreendedorismo; }\end{array}$ & $\begin{array}{l}\text { Happy Hours; } \\
\text { Rede alumni. }\end{array}$ \\
\hline $\begin{array}{l}\text { Possíveis métricas } \\
\text { quantitativas } \\
\text { apresentadas pelas } \\
\text { organizações }\end{array}$ & $\begin{array}{l}\text { Número de pessoas } \\
\text { atingidas nos eventos; } \\
\text { número de atividades } \\
\text { realizadas; número de } \\
\text { projetos nascentes } \\
\text { gerados. }\end{array}$ & $\begin{array}{l}\text { Número de projetos } \\
\text { externos auxiliados; } \\
\text { número de startups } \\
\text { completando a pré- } \\
\text { aceleração; número de } \\
\text { projetos nascidos } \\
\text { sobreviventes. }\end{array}$ & $\begin{array}{l}\text { Percentual de } \\
\text { membros antigos } \\
\text { empreendendo; } \\
\text { número de } \\
\text { organizações } \\
\text { parceiras. }\end{array}$ \\
\hline
\end{tabular}

FONTE: Elaborado pelo autor. 


\subsection{Modelo de Maturidade para organizações estudantis grassroots voltadas para empreendedorismo}

Como elemento final da proposta da presente dissertação, a validação de um modelo de maturidade para o cenário de universidades de pesquisa brasileiras se deu com base em todos os dados organizados a partir dos múltiplos casos - de modo a, por fim, orientar organizações grassroots voltadas para empreendedorismo quanto aos estágios de maturidade e as etapas necessárias para cada estágio. Os elementos do modelo de maturidade foram baseados no tratamento de dados feito com a validação no modelo NACUE, que, adaptado ao contexto nacional, se formatou em 10 indicadores: (i) estratégia, (ii) governança, (iii) processos internos, (iv) sucessão e (v) relações internas, (vi) relações externas, (vii) impacto gerado e negócios criados, (viii) portfólio de captação financeira, (ix) marketing e branding e (x) programação de atividades e eventos. Outros elementos identificados no presente estudo também foram acrescentados e, baseando-se nas propostas de Cukier, Kon e Krueger (2015) e Compass.co (2015), propõe-se um modelo de maturidade com quatro estágios: nascente, em consolidação, maduro e autossustentável. O modelo compila e propõe uma segmentação para pontos identificados na teoria que ajudam a responder a pergunta de pesquisa, pontos apresentados no relato descritivo e pontos apresentados nos relatos de experiência.

Tabela 9 - Características encontradas nos estágios de maturidade de organizações estudantis grassroots para empreendedorismo

\begin{tabular}{|c|l|}
\hline $\begin{array}{c}\text { Estágios de } \\
\text { maturidade }\end{array}$ & \multicolumn{1}{c|}{ Características apresentadas para os estágios } \\
\hline Nascente & $\begin{array}{l}\text { Identificação dos gaps da universidade que podem ser cobertos; } \\
\text { Compreensão dos conceitos envolvendo empreendedorismo; } \\
\text { Realização de primeiras atividades de inspiração/estímulo; } \\
\text { Mapeamento de rede de apoiadores; } \\
\text { Atração de membros para o movimento. }\end{array}$ \\
\hline \multirow{2}{*}{ Em consolidação } & $\begin{array}{l}\text { Formação de lideranças com compromisso de longo prazo; } \\
\text { Início da organização de processos nas operações; } \\
\text { Aumento no volume de atividades e início de atuação com capacitação/ensino e } \\
\text { conexão/estrutura. }\end{array}$ \\
\hline
\end{tabular}




\begin{tabular}{|c|l|}
\hline Maduro & $\begin{array}{l}\text { Estrutura de governança e lideranças estabelecidas frente a situações de crise; } \\
\text { Solidez no posicionamento e na rede de apoiadores; } \\
\text { Atividades nos três pilares estruturadas e primeiros casos de sucesso; } \\
\text { Transbordamento de ações com impacto regional efetivo; } \\
\text { Cultura e operações bem definidas, com início de acúmulo de recursos. }\end{array}$ \\
\hline Autossustentável & $\begin{array}{l}\text { Impacto e participação efetiva nos esforços institucionais; } \\
\text { Posicionamento/branding com destaque, atraindo membros para a organização, } \\
\text { alunos para atividades e relacionamentos estratégicos; } \\
\text { Fontes sólidas e diversificadas de recursos; } \\
\text { Gestão de conhecimento, sucessão e governança com processos claros; } \\
\text { Reconhecimento regional pelo volume de casos de sucesso. }\end{array}$ \\
\hline
\end{tabular}

FONTE: Elaborado pelo autor

O Modelo de Maturidade do National Association of College and University Entrepreneurs (NACUE) do Reino Unido se desenvolveu com o objetivo de permitir à organização uma maneira de avaliar e direcionar os esforços das participantes - na época do modelo, 2012, 83 organizações. Adaptando ao fenômeno recente nacional - sem uma associação nacional com força e recursos para implementação de avaliações em escala similar, esperou-se mais um marco referencial para nortear as organizações grassroots brasileiras, bem como os gestores relacionados às instituições de ensino em que se inserem, quanto aos pilares e estágio de desenvolvimento de cada elemento em um processo de maturidade. Deste modo, além dos estágios, propõe-se uma organização relativa ao que é esperado das organizações em cada estágio de maturidade para os pilares do modelo NACUE validados pelo estudo de casos em um contexto brasileiro.

Tabela 10 - Estrutura do Modelo de Maturidade NACUE adaptada: Pilares x Estágios de Maturidade

\begin{tabular}{|l|l|l|l|l|}
\hline & \multicolumn{1}{|c|}{ Nascente } & \multicolumn{1}{|c|}{ Em consolidação } & \multicolumn{1}{c|}{ Maduro } & \multicolumn{1}{|c|}{ Autossustentável } \\
\hline Estratégia & $\begin{array}{l}\text { Identificação de } \\
\text { gaps e ações }\end{array}$ & Definição de missão & $\begin{array}{l}\text { Estratégias e visão de } \\
\text { longo prazo }\end{array}$ & $\begin{array}{l}\text { Foco em expansão e } \\
\text { impacto }\end{array}$ \\
\hline Governança & Inexistente & Estágio inicial & Bem estruturada & Efetiva \\
\hline $\begin{array}{l}\text { Processos } \\
\text { Internos }\end{array}$ & Inexistentes & Estágio inicial & Processos organizados & $\begin{array}{l}\text { Cultura de execução } \\
\text { clara }\end{array}$ \\
\hline Sucessão & Inexistente & $\begin{array}{l}\text { Foco em formação de } \\
\text { lideranças }\end{array}$ & $\begin{array}{l}\text { Madura após crises e } \\
\text { rotatividade }\end{array}$ & $\begin{array}{l}\text { Gestão do } \\
\text { conhecimento }\end{array}$ \\
\hline $\begin{array}{l}\text { Relações } \\
\text { internas }\end{array}$ & $\begin{array}{l}\text { Ações de atração de } \\
\text { membros }\end{array}$ & $\begin{array}{l}\text { Parcerias com outras } \\
\text { iniciativas }\end{array}$ & $\begin{array}{l}\text { Reconhecimento na } \\
\text { Universidade }\end{array}$ & $\begin{array}{l}\text { Influência na } \\
\text { Universidade }\end{array}$ \\
\hline
\end{tabular}




\begin{tabular}{|l|l|l|l|l|}
\hline $\begin{array}{l}\text { Relações } \\
\text { externas }\end{array}$ & $\begin{array}{l}\text { Mapeamento de } \\
\text { apoiadores }\end{array}$ & $\begin{array}{l}\text { Construção de uma } \\
\text { rede de apoio }\end{array}$ & $\begin{array}{l}\text { Rede forte e gerando } \\
\text { conexões }\end{array}$ & $\begin{array}{l}\text { Reconhecimento e } \\
\text { impacto regional }\end{array}$ \\
\hline $\begin{array}{l}\text { Impacto } \\
\text { gerado / } \\
\begin{array}{l}\text { Negócios } \\
\text { criados }\end{array}\end{array}$ & Inexistente & $\begin{array}{l}\text { Primeiras ações de } \\
\text { suporte e conexão }\end{array}$ & $\begin{array}{l}\text { Primeiros casos de } \\
\text { sucesso }\end{array}$ & $\begin{array}{l}\text { Reconhecimento pelo } \\
\text { volume }\end{array}$ \\
\hline $\begin{array}{l}\text { Portifólio de } \\
\text { captação } \\
\text { financeira }\end{array}$ & Inexistente & $\begin{array}{l}\text { Mapeamento de } \\
\text { potenciais fontes }\end{array}$ & $\begin{array}{l}\text { Saudável para } \\
\text { executar projetos }\end{array}$ & $\begin{array}{l}\text { Diversificado e } \\
\text { gerando caixa }\end{array}$ \\
\hline $\begin{array}{l}\text { Marketing e } \\
\text { branding }\end{array}$ & $\begin{array}{l}\text { Esforços ligados a } \\
\text { atração }\end{array}$ & $\begin{array}{l}\text { Grande ênfase no uso } \\
\text { de mídias }\end{array}$ & $\begin{array}{l}\text { Comunicação ampla e } \\
\text { eficaz }\end{array}$ & $\begin{array}{l}\text { Responsável por forte } \\
\text { atração }\end{array}$ \\
\hline $\begin{array}{l}\text { Programação } \\
\text { de atividades e e } \\
\text { eventos }\end{array}$ & Grande ênfase & $\begin{array}{l}\text { Amadurecimento e } \\
\text { personalização }\end{array}$ & $\begin{array}{l}\text { Alto impacto e } \\
\text { transbordamentos }\end{array}$ & $\begin{array}{l}\text { Alto impacto e } \\
\text { transbordamentos }\end{array}$ \\
\hline
\end{tabular}

FONTE: Elaborado pelo autor

\subsection{Conclusão da dissertação}

O tópico de encerramento desta pesquisa trata-se e um exercício de navegação em maneira reversa pelo trabalho produzido, visando melhor esclarecimento e resposta à pergunta de pesquisa proposta: como os movimentos grassroots, liderados por alunos, podem desempenhar um papel efetivo no incentivo ao empreendedorismo em universidades de pesquisa brasileiras?

A resposta, em seu escopo metodológico, tinha como objetivo descrever boas práticas de múltiplos casos e apresentar um marco referencial que pudesse nortear os esforços de tais organizações a partir de um Modelo de Maturidade reconhecido internacionalmente ambos objetivos que tiveram seu cumprimento realizado do ponto de vista científico. Indo além, realizando o exercício de navegação reversa pelo trabalho - mesmo que de modo superficial e com finalidade de consolidar aprendizados - pode-se tirar alguns pontos conclusivos:

- Na imersão teórica, o leitor pode compreender com maior detalhamento a caracterização dos conceitos de empreendedorismo e a importância dos ecossistemas de empreendedorismo. Tais elementos se mostram úteis quando carregam consigo a reflexão sobre parceiros estratégicos para uma organização grassroots de incentivo ao empreendedorismo e quando estimulam ações de mapeamento e ativação de relacionamentos.

- Os pontos sobre os papéis da universidade em ecossistemas de empreendedorismo e os exemplos de universidades reconhecidas como referências no incentivo ao empreendedorismo auxiliam gestores - de universidades, de organizações e até 
mesmo gestores públicos - a melhor compreender a diversidade de papéis que podem ser desempenhados por universidades em um papel efetivo no incentivo à criação de empresas. Carregam consigo também a importância de se construir comunidades e, a partir da geração de caso de sucessos, aumentar o potencial de novos casos com os transbordamentos positivos de Isenberg.

- A elucidação do fenômeno grassroots para empreendedorismo ao redor do mundo, bem como a apresentação da história de embrionário sucesso de variados casos brasileiros, mostram a relevância do tema para as universidades do País - e servem como orientação para que universidades brasileiras aprendam a fomentar esse tipo de organismo sem tolhir a autonomia do mesmo.

- Os aspectos comportamentais, humanos e relacionados às redes de relacionamento reforçam a importância das pessoas nas organizações, especialmente de incentivo a empreendedorismo e inovação. Para o estímulo a esse tipo de iniciativa, espera-se muito mais que investimento e infraestrutura e apoio: os relatos reforçam que é necessário o devido cuidado com o fator humano e com os talentos envolvidos.

Cabe a compreensão do processo evolutivo estrutural do modelo grassroots, que inicialmente começa como um movimento de interessados realizando atividades e atraindo colegas interessados, evolui para uma iniciativa mais formalizada, porém sem estrutura jurídica e, por fim, se formaliza (se apropriando de CNPJ e de uma rede estratégica) como organização grassroots. Quando organização madura, desempenha profunda influência na capacidade de ouvir os alunos e enxergar novas soluções, de apoiar professores no desempenho de atividades e de influenciar as estratégias institucionais. Sendo esta evolução de suas atividades em um caminho bottom-up, ao invés da abordagem institucional, cujo caminho se dá top-down. Ao longo dos relatos e levantamentos nos casos, também foi percebida uma tensão dentro do paradoxo existente no papel da universidade frente ao desenvolvimento de movimentos grassroots: um apoio valioso para garantir a plena evolução do movimento versus o risco de se fagocitar o mesmo e fazer com que perca força e acabe. À universidade, o estudo sinaliza sugerir uma compreensão dos movimentos, uma atenção aos seus estágios de maturidade e os seguintes mecanismos e cuidados frente a desafios: 
Tabela 11 - Tensão entre suporte e risco na ação institucional para com o desenvolvimento do modelo grassroots

\begin{tabular}{|l|l|l|l|}
\hline \multicolumn{1}{|c|}{$\begin{array}{c}\text { Estágio de } \\
\text { maturidade }\end{array}$} & Desafios enfrentados & Suporte institucional & Riscos aos grassroots \\
\hline Nascente & $\begin{array}{l}\text { Falta de posicionamento; } \\
\text { falta de experiência. }\end{array}$ & $\begin{array}{l}\text { Conexão com } \\
\text { professores e } \\
\text { parceiros; } \\
\text { comunicação ampla. }\end{array}$ & $\begin{array}{l}\text { Dependência e perda de } \\
\text { autonomia para agendas } \\
\text { institucionais. }\end{array}$ \\
\hline Em consolidação & $\begin{array}{l}\text { Falta de infraestrutura; } \\
\text { falta de consistência em } \\
\text { ações. }\end{array}$ & $\begin{array}{l}\text { Infraestrutura; } \\
\text { direcionamento de } \\
\text { oportunidades. }\end{array}$ & $\begin{array}{l}\text { Influência e exigências } \\
\text { excessivas; barreiras } \\
\text { burocráticas e } \\
\text { financeiras. }\end{array}$ \\
\hline Maduro & $\begin{array}{l}\text { Problemas de } \\
\text { rotatividade e } \\
\text { dificuldades na escala. }\end{array}$ & $\begin{array}{l}\text { Suporte em recursos; } \\
\text { co-realização de } \\
\text { atividades maiores; }\end{array}$ & $\begin{array}{l}\text { Interesse em } \\
\text { institucionalização e } \\
\text { engessamento; perda de } \\
\text { protagonismo. }\end{array}$ \\
\hline Autossustentável & $\begin{array}{l}\text { Ampliação de impacto e } \\
\text { expansão física. }\end{array}$ & $\begin{array}{l}\text { Suporte à expansão } \\
\text { física, atração de } \\
\text { parceiros maiores e } \\
\text { co-desenho de } \\
\text { estratégias } \\
\text { institucionais. }\end{array}$ & $\begin{array}{l}\text { Erros envolvendo grande } \\
\text { volume de atingidos; } \\
\text { riscos envolvendo } \\
\text { representação de uma } \\
\text { marca institucional. }\end{array}$ \\
\hline
\end{tabular}

FONTE: Elaborado pelo autor

Uma outra conclusão importante está ligada aos resultados provenientes da capacidade de execução dos organismos grassroots. Sendo os mesmos diferenciados pela autonomia e menores níveis de burocracia devido à característica informal em seus primeiros momentos, espera-se maior potencial de execução por parte dos mesmos - fator que atrai para si bons resultados e, consequentemente, apoiadores de maior relevância institucional. Ao passo que as entregas passam a ser realizadas, cresce o nível de confiança e capacidade sinérgica com mecanismos institucionais - característica central do amadurecimento dos grassroots. Deste modo, uma postura reativa por parte destes organismos (esperando que tenham infraestrutura completa para pleno desenvolvimento de suas funções, por exemplo) contraria a necessidade central de seu processo de gênese: a autonomia proativa e a capacidade de atuar como protagonista no ambiente em que se insere.

Quanto à contrapartida institucional, cabe às universidades brasileiras compreender o poder de transformação que vem das raízes, de baixo para cima, e catalisar tal potencial com clareza e consistência. Como na teoria foi apresentado, há uma crescente compreensão do potencial destes grupos por parte de alguns professores, gestores 
educacionais e pesquisadores - sendo este um trabalho fundamental para gestores educacionais no sentido de melhor compreender as dinâmicas evolutivas e interesses estudantis presentes na instituição. O mapeamento das entidades estudantis de uma maneira geral (empresas juniores, grupos de competição, entidades para empreendedorismo entre outros) mostra-se como um exercício importante para catalisar resultados e, inclusive, otimizar a utilização de recursos da universidade.

Permitindo o desenvolvimento pleno dessas organizações, a presente dissertação trouxe o que se comprometeu no planejado: um elemento descritivo para melhor elucidar ações (relatos e aprendizados compilados) e um elemento normativo para nortear a evolução dos grassroots estudantis para empreendedorismo (modelo de maturidade validado e contextualizado). Cabendo, a partir disto, às universidades e às organizações estudantis grassroots para empreendedorismo o trabalho mútuo de uma missão em comum ligada ao ato de elevar a competitividade e a economia da nação.

Como limitações do estudo, ressalta-se a natureza exploratória e a abordagem qualitativa do mesmo - escolhida para valorizar a profundidade das experiências vividas e abrir caminhos para estudos futuros, mas que traz consigo riscos envolvendo vieses pessoais que poderiam ser melhor minimizados utilizando métodos quantitativos com tamanho amostral estatisticamente significativo. O método escolhido, Estudo de Múltiplos Casos, também carrega seus riscos em termos de generalização de contextos individuais, além dos outros riscos supracitados. Um outro elemento ligado à capacidade de alcance na amostra dos entrevistados é o caráter regional - concentrando a atuação no Sudeste brasileiro, podendo haver pontos cegos encobrindo elementos que podem vir a ser relevantes em outras regiões do país.

Deste modo, a primeira sugestão para estudos futuros é o avanço do presente estudo para uma abordagem quantitativa: buscando abordar as dezenas de organizações grassroots nascentes em universidades brasileiras e aprofundar a validação do Modelo de Maturidade, inclusive propondo métricas tangíveis para potenciais esforços de avaliação desses organismos - podendo gerar ferramentas úteis, como mapas de radar, gráficos comparativos entre outros. Uma outra expansão do uso do Modelo de Maturidade pode vir a ser a exploração de um Modelo voltado para a evolução de universidades rumo a empreendedorismo no Brasil, sendo a força dos grassroots um dos indicadores estratégicos a ser considerado. Ademais, com o crescimento do tema grassroots para 
empreendedorismo, espera-se que se abram horizontes para estudos mais específicos, tais como estudos de caso apresentando sucesso na relação institucional versus grassroots, estudos com boas práticas e ferramentas para grassroots, bem como revisões de literatura mais aprofundadas, como já encontrado modelo similar na bibliografia da presente dissertação. Reforça-se aqui o caráter do modelo grassroots, que pode se aplicar para outros mecanismos - como iniciativas de professores já percebidas durante o estudo ou como a criação de entidades não diretamente vinculadas a empreendedorismo (empresas juniores, grupos de competição e outros). Estes plurais formatos podem também se beneficiar de muitos elementos apresentados no presente estudo, visto que o fenômeno grassroots trata-se de uma abordagem na qual se desenvolvem iniciativas organizadas, não somente se limitando a entidades ligadas a empreendedorismo dentro de universidades de pesquisa. 


\section{REFERÊNCIAS BIBLIOGRÁFICAS}

ACS, Z. J.; DESAI, S.; HESSELS, J. Entrepreneurship, economic development and institutions. Small Business Econonomic. 2008.

AEP. 2016. Alunos da Poli e da EESC USP vencem competição de tecnologia na Europa. Associação dos Engenheiros Politécnicos. Disponível em:

$<$ http://politecnicos.org.br/index.php/noticias/alunos-da-poli-e-da-eesc-usp-vencemcompeticao-de-tecnologia-na-europa/> Acesso em: 29/07/2016.

AGUILHAR, L. 2015a. Startups em busca de mais espaço na USP. Link - Estadão.

Disponível em: <http://link.estadao.com.br/noticias/geral,startups-em-busca-de-maisespaco-na-usp,10000029250> Acesso em: 29/07/2016.

. 2015b. Maior cena de startups brasileira; São Paulo é marcada por pulverização.

Link - Estadão. Disponível em: < http://link.estadao.com.br/noticias/inovacao,maior-cenade-startups-brasileira-sao-paulo-e-marcada-por-pulverizacao,10000029554> Acesso em: 29/07/2016.

2014. USP terá 'força-tarefa' para criar startups neste fim de semana. Link -

Estadão. Disponível em: <http://link.estadao.com.br/blogs/start/usp-tera-forca-tarefa-paracriar-startups-neste-fim-de-semana/> Acesso em: 29/07/2016.

ALEXANDRE, J. W. C. et al. Análise do número de categorias da escala de Likert aplicada à gestão pela qualidade total através da teoria da resposta ao item. XXIII Encontro Nacional de Engenharia de Produção. 2003.

ANDREASSI, T. et al. Global Entrepreneurship Monitor. Empreendedorismo no Brasil: 2011. Curitiba: IBPQ, 2011.

ASSOCIATION, S. V. H. 1992-2016. Hewlett-Packard Company History. Silicon Valey Historical Association. Disponível em: $<\underline{\text { http://www.siliconvalleyhistorical.org/\#!hewlett- }}$ packard-company-history/c38e> Acesso em: 20/06/2014. 
BESSANT, J.; TIDD, J. Inovação e Empreendedorismo. Porto Alegre: Ed Bookman, 2009.

BOOKER, L. C. Encouraging Entrepreneurship: Brazil's Bid in Latin America. Journal of International Affairs. Columbia. 2013.

BORISON, R. 2014. The Most Successful College Fraternities In Tech. Business Insider. Disponível em: <http://www.businessinsider.com/the-most-successful-frats-in-tech-20146? op $=1>$ acesso em: 20/06/2014.

BROWN, T. Design Thinking - Uma Metodologia Poderosa para Decretar o Fim das Velhas Ideias. Campus. 2010.

CARDWELL, W. 2012. Designing Entrepreneurial Aalto. International Conference on Fostering entrepreneurship and innovation ecosystem. Kaunas University of Technology. Disponível em: < http://www.slideshare.net/willcardwell/designingentrepreneurial-aalto-ktu-12-11-30> Acesso em: 20/05/2015.

CAREgnATO, R. C. A.; MUTTI, R. Pesquisa Qualitativa: Análise de Discurso versus Análise de Conteúdo. Texto Contexto Enferm. Florianópolis. Out-dez, 15 (4): 679-84. 2006.

CHWOLKA, A.; RAITH, M. G. The value of business planning before start-up - A decision-theoretical perspective. Journal of Business Venturing, 27: 385-399. 2012.

CLARYSSE, B., BRUNEEL, J.; WRIGHT, M. Explaining Growth Paths of Young Technology-Based Firms: Structuring Resource Portfolios in Different Competitive Environments. Strategic Entrepreneurship Journal, 5: 137-157. 2011.

CLARK, B. R. Development of the Sociology of Higher Education. Sociology of Education. American Sociological Association. v. 46, n. 1, p 2-14,1973. 
CHEN, L. 2014. Startup Schools: America's Most Entrepreneurial Universisties. Forbes Lists. Disponível em: < http://www.forbes.com/sites/liyanchen/2014/07/30/startup-schoolsamericas-most-entrepreneurial-universities/ > Acesso em 20/05/2015.

COMPASS.CO. Waterloo Startup Ecosystem Report. The Startup Ecosystem Report Series. 2015.

CORTELLA, M. S. Educação, convivência e ética: audácia e esperança! Cortez Editora, 2015.

CUKIER, D.; KON, F.; KRUEGER, N. Software Startup Ecosystem Maturity Model Technical Report. PROFES'2015 Workshop on Software Startups: State of the Art and State of Pratice. 2015

DAHLSTRAND, A. L. Technology-based entrepreneurship and regional development: The case of Sweden. European Business Review. Bradford, v. 19, n.5, p 373-386, 2007.

DRUCKER, P. F. Inovação e espírito empreendedor (entrepreneurship): prática e princípios. 5. ed. São Paulo: Pioneira, 1985.

ENDEAVOR. O Empreendedorismo Nas Universidades Brasileiras. Endeavor Brasil, 2012.

ETZKOWITZ, H. et al The future of the university and the university of the future: evolution of ivory tower to entrepreneurial paradigm. Research Policy, 29, p 313-330. 2000 .

MIT and the Rise of Entrepreneurial Science. Studies in Global Competition Series. Routledge. 2003.

. Stanford and Silicon Valley: The Co-Evolution of Technology Transfer and Regional Absorptive Capacity. Triple Helix IX International Conference: Silicon Valley: Global Model or Unique Anomaly? Stanford University. Jul, 2011. 
. StartX and the 'Paradox of Success': Filling the gap in Stanford's entrepreneurial culture. Social Science Information, 52, p 605-627. 2013.

EWERS, J. 2015. Líder do interior, Campinas traz na história sua vocação para inovação. Inovação Revista Eletrônica em P,D\&I. Disponível em:

$<$ http://www.inovacao.unicamp.br/especial/lider-do-interior-campinas-traz-na-historia-suavocacao-para-inovacao/> Acesso em: 13/02/2016.

FELD, B. Startup Communities: building na entrepreneurial ecosystem in your city. Ed. Wiley. 2012

FERMINO, R. 2011. Centro Minerva de Empreendedorismo Poli/USP. Blog - Roberto Fermino. Disponível em: <http://www.robertofermino.com/blog/>. Acesso em: $15 / 06 / 2014$.

. Startupapo: Conversas com Empreendedores Digitais. Amazon Digital Services. 2014.

FOWLER F. R. Programa de Desenvolvimento de Empreendedorismo - PDEs. Um Estudo de Caso. FEA-USP e DUBS. São Paulo, 1997.

FU, E.; HSIA, T. 2013-2016. "Universities and Entrepreneurial Ecosystems: Elements of the Stanford-Silicon Valley Success". Kauffman Fellows Press. Disponível em: $<$ http://www.kauffmanfellows.org/journal_posts/universities-and-entrepreneurialecosystems-stanford-silicon-valley-success $>$ Acesso em: 16/03/2015.

GARTNER, W. B. A conceptual framework for describing the phenomenon o new venture creation. Academy of Management Review, v. 10, n. 4, p 696-706, 1985.

GAZZONI, M. 2014. Easy Taxi vai de startup a múlti presente em 30 países. Revista Exame. Disponível em: $\quad<$ http://exame.abril.com.br/pme/noticias/de-startup-amultinacional-presente-em-30-paises> acesso em: 29/07/2016.

GEDI. Gedi Index. Global Entrepreneurship Development Institute. 2014. 
GIBB, A. A. Entrepreneurship and small Business Management: Can we afford to neglect them in the twenty-first century business school? British Journal of Management, 7:4, p 309-324, 1996.

GLAESER, E. L.; KERR, W. R. What Makes a City Entrepreneurial? Policy Briefs. Rappaport Institute/Taubman Center. Harvard Kennedy School, 2010.

GOLDBER, D.; SOMERVILlE, M. A Whole New Engineer: The Coming Revolution in Engineering Education. ThreeJoy Associates Inc. 2014.

. 2012. Three Habits at Three Levels for Improved Engineering Education.

Huffpost Education- The Huffington Post. Disponível em: < http://www.huffingtonpost.com/david-goldberg/3-habits-at-3-levels-for-_b_1751699.html> Acesso em 18/10/2015.

GONÇALVES, E. P.. Iniciação à pesquisa científica. (4. ed.) - revisada e atualizada. Campinas, SP: Editora Alínea. 2007.

GRAHAM, R.. Creating university-based entrepreneurial ecosystems: evidence from emerging world leaders. MIT Skoltech Initiative. Jun, 2014.

GRAHAM, P. 2013. Do thing's that don't scale. Paul Graham Essays. Disponível em < http://paulgraham.com/ds.html> Acesso em 18/10/2015.

HAAN, U. GOLANY, B. The land of milk, honey and ideas: What makes Israel a hotbed for entrepreneurship and innovation? In: Global Perspectives on Technology Transfer and Commercialization. Edward Elgar Publishing. 2011.

HARASYMCZUK, M. 2014. Spotify Engineering Culture part 1 (Agile Enterprise Transition with Scrum and Kanban). Disponível em: < https://www.youtube.com/watch?v=Mpsn3WaI 4k> Acesso em: 18/10/2015 
HARMAN, D. 2013. The Technion: Israel's Hard Drive. The New York Times -

Education Life. Disponível em:

$<\underline{\text { http://www.nytimes.com/2013/04/14/education/edlife/inside-the-technion-israels-premier- }}$ technological-institute-and-cornells-global-partner.html> Acesso em 20/05/2015.

HOSSAIN, M. Grassroots Innovation: A Systematic Review of Two Decades of Research. Journal of Cleaner Production. July, 2016.

ISENBERG, D. How to Start an Entrepreneurial Revolution. Harvard Business Review, 2010.

. The Entrepreneurship Ecosystem Strategy as a New Paradigm for Economic Policy: Principles for Cultivating Entrepreneurship. The Babson Entrepreneurship Ecosystem Project, 2011

KATZ, J. A. The chronology and intellectual trajectory of American entrepreneurship education: 1876-1999. Journal of Business Venturing. vol. 18. p. 283-300. 2003.

KASABOV, E. Start-Up Difficulties in Early-Stage Peripheral Clusters: The Case of IT in an Emerging Economy. Entrepreneurship Theory and Pratice, 39(4): 727-761. 2013.

KEZAR, A; GALLANT, T. B.; LESTER, J.. Everyday people making a difference on college campuses: the tempered grassroots leadership tactics of faculty and staff. Studies in Higher Education, vol. 36, issue 2, 2011.

KIRBY, D. A. Entrepreneurship Education: Can Business Schools Meet the Challenge? Internacional Councill of Small Business. $47^{\text {th }}$ World Conference, 2002.

KLICH, T. B. 2014. Top 50 Universities for VC-Baked Entrepreneurs. Entrepreneur. Disponível em: < http://www.entrepreneur.com/article/236912> Acesso em: 20/05/2015.

KON, F. et al. 2014. A panorama of the Israeli Software Startup Ecosystem. Social Science Research Network. Disponível em:

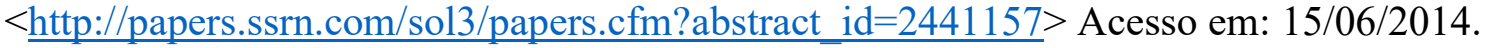


KRAKAUER, P. V. C. Ensino de Empreendedorismo: Estudo Exploratório sobre a Aplicação da Teoria Experiencial. Tese de Doutorado. Faculdade de Economia e Administração da Universidade de São Paulo, 2014.

LAREDO, P. Toward a third mission for Universities. The third mission of Universities. UNESCO Workshop. 2007.

LEHDONVIRTA, V. The Helsinki Spring: an essay on entrepreneurship and cultural change. Discussions. Research on Finnish Society. Vol. 6, p. 25-28. 2013

LEMOS, P. A. B. Universidades e ecossistemas de empreendedorismo: a gestão orientada por ecossistemas e o empreendedorismo da Unicamp. Editora Unicamp. 2012.

LEVIN, J. 2015. Venture Capital Heads to Brazil, Defying Economic Slump. Bloomberg Business. Disponível em: <http://www.bloomberg.com/news/articles/2015-05-05/venturecapital-heads-to-brazil-defying-economic-slump > Acesso em: 20/05/2015.

LOW, M. B.; MACMILLAN, I. C. Entrepreneurship: Past Research And Future Challenges. Journal of Management, 14, n-2, p. 139-161. 1988.

MAEDA, J. 2016. Is Business School the New Design School? Crunch Network. Aol Inc. Disponível em: $\quad<$ https://techcrunch.com/2016/06/21/is-business-school-the-new-designschool/> Acesso em: 25/06/2016.

MATTAR, F. N. Pesquisa de Marketing. 4. ed. São Paulo: Atlas, 2007.

MARCOVITCH, J. Pioneiros e Empreendedores - A saga do desenvolvimento no Brasil Vol. 3. São Paulo: Editora da Universidade de São Paulo \& Editora Saraiva, 2007.

MARTINS, P. S. Spin-offs da ciência: terras raras do empreendedorismo acadêmico brasileiro? Dissertação (Mestrado) - Escola Politécnica da Universidade de São Paulo. São Paulo. 2014. 
MAZZON, J. A. Análise do programa de alimentação do trabalhador sob o conceito de marketing social. Tese (Doutorado) - Faculdade de Economia, Administração e Contabilidade da Universidade de São Paulo. São Paulo. 1981.

MCKEON, T. K. A College's Role in Developing and Supporting an Entrepreneurship Ecosystem. Journal of Higher Education Outreach and Engagement, v. 17, n.3, p.85, 2013.

MORRIS, R.; PENIDO, M. How did Silicon Valley Became Silicon Valley? Three Surprising Lessons for Other Cities and Regions. Endeavor Insight. Jul, 2014.

NACUE. Nacue in a Nutshell. NACUE - Stimulating university enterprise. 2009. . Maturity Model Annual Report. National Consortium of University Entrepreneurs. 2012.

NADGRODKIEWICZ, A. Building Entrepreneurship Ecosystems at Creating the Environment for Entrepreneurial Success. Center for International Private Enterprise. 18-21. 2014.

NEU. 2013. Núcleo de Empreendedorismo da USP. Disponível em: $<$ http://www.uspempreende.org $>$ acesso em 07/06/2014.

NEU. 2016. Núcleo de Empreendedorismo da USP - Youtube. Disponível em: < https://www.youtube.com/channel/UCatZIOtce2CNt-ykMibS1nA/videos > Acesso em: $13 / 02 / 2016$.

NEXT, S. 2013. NEXT Customer Discovery Program - What Do You Ask with Justin

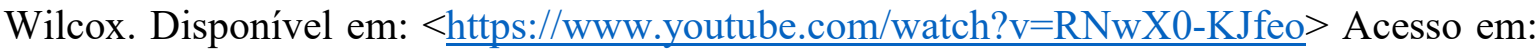
$18 / 10 / 2015$.

NYMAN, G. S. University-business-government collaboration:from institutes to platforms and ecosystems Triple Helix Journal. (2:2), 2015. 
OLIVEIRA, C; CASTRO, T. 2015. Empreendedorismo na USP: alunos se aventuram no universo das startups. CIETEC Notícias. Disponível em: < http://www.cietec.org.br/empreendedorismo-na-usp-alunos-se-aventuram-no-universo-dasstartups/>. Acesso em: 29/07/2016.

ORTMANS, J. 2012. What's next for Finland? Global Entrepreneurship Network. Disponível em: < http://bw.gew.co/what's-next-finland> acesso em: 14/06/2014.

OSTERWALDER, A.; PIGNEUR, Y. Business Model Generation: A Handbook for Visionaries, Game Changers, and Challengers. John Wiley and Sons. 2010.

PENWARDEN, B. Society Impact Report. NACUE - National Consortium of University Entrepreneurs. 2013.

PERES, S. 2016. Following Maimonides. The Jerusalem Post. Disponível em: $<$ http://www.jpost.com/Opinion/Following-Maimonides-462071>. Acesso em: 29/07/2016.

PITTAWAY, L. et al The role of entrepreneurship clubs and societies in entrepreneurial learning. International Small Business Journal. vol. 29 no. 1 37-57. Fev. 2011.

PLONSKI, G. A.; CARRER, C. C. A Inovação Tecnológica e a Educação para o Empreendedorismo. In USP 2034: Planejando o Futuro - Organizadores: Suely Vilela, Franco Maria Lajolo. - São Paulo: Editora da Universidade de São Paulo, p 107, 135. 2009.

PURSULA, M. The Grand Challenges - challenging universities of technology to change. Cesaer Grand Challenges Seminar. Aalto University, Finland. 2010.

QUAINO, L. 2013. Edital de chamada pública para 'Start-Up Brasil' é lançado no Rio. G1, disponível em: < http://g1.globo.com/economia/pme/noticia/2013/03/edital-de-chamadapublica-para-start-brasil-e-lancado-no-rio.html> acesso em: 14/06/2014.

REGELE, M. D.; NECK, H. M. The Entrepreneurial Education Sub-Ecosystem In the United States: Opportunities to Increase Entrepreneurial Activity. Journal of Business and Entrepreneurship, Winter, p 25-47. 2012. 
RIBEIRO, A. T. V. B.; PLONSKI, G. A.; ORTEGA L. M. Um fim, dois meios: Aceleradoras e Incubadoras no Brasil. XVI Congresso Latino-Iberoamericano de Gestão da Tecnologia. 2015.

RIES, E. The Lean Startup: How Today's Entrepreneurs Use Continuous Innovation to Create Radically Successful Businesses. Crown Business. 2011.

RIGBY, D. K.; SUTHERLAND, J.; TAKEUCHI, H. Embracing Agile. Harvard Business Review. 2016.

RITONDALE, C. A. Visões de um Educador. Clube de autores. 2008.

ROBERT, E. B.; EESLEY, C. Entrepreneurial Impact: The Role of MIT. Kauffman - The Foundation of Entrepreneurship. 2009.

RUA, C. 2016. O NEU tem muitas histórias de sucesso para contar. Ciência na Rua. Disponível em: < http://ciencianarua.net/o-neu-tem-muitas-historias-de-sucesso-paracontar/> Acesso em: 29/07/2016.

SANDBERG, S. 2015. How does Sheryl Sandberg plan her day? Quora. Disponível em: < https://www.quora.com/How-does-Sheryl-Sandberg-plan-her-day> Acesso em: 13/02/2016.

SANTANDER. 2016. Prêmio Santander Universidades. Santander Universidades. Disponível em: $<\underline{\text { https://www.santanderuniversidades.com.br/premios/paginas/default.aspx }}>$ Acesso em: $13 / 02 / 2016$.

SAXENIAN, A. "The origins and dynamics of production networks in Silicon Valley." Research Policy 20, no. 5: 423-437. 1991.

SEELIG, T. Se eu soubesse aos 20. São Paulo: Editora da Boa Prosa, 2011. 
SENOR, D.; SINGER, S. Nação Empreendedora - O milagre econômico de Israel e o que ele nos ensina. Editora Évora, 2011.

SCHUMPETER, J. A. Capitalism, socialism and democracy. London: Routledge, 1942.

SINGER, S.; AMORÓS, J. E.; ARREOLA, D. M. Global Entrepreneurship Monitor Global Report 2014. Babson College, Universidad Del Desarrollo, UniversitiTun Abdul Razak, Tecnológico de Monterrey, London Business School. 116p. 2015.

SMITH, M. 2011. The Rise Of A Grassroots Entrepreneurial Movement. Management Innovation Exchange. Disponível em <http://www.mixprize.org/story/rise-grassrootsentrepreneurial-movement? challenge $=14226>$ Acesso em 18/10/2015.

SOCIETY, A E. About Aaltoes. 2016. Aalto Entrepreneurship Society. Disponível em: < http://aaltoes.com/about/> Acesso em: 13/02/2016.

STANGLER, D.; BELL-MATERSON, J. Measuring an Entrepreneurial Ecosystem. Kauffman Foundation Research Series on City, Metro and Regional Entrepreneurship. 2015.

STARTUPAPO. 2011. Núcleo de Empreendedorismo da USP. SlideShare. Disponível em: $<$ http://www.slideshare.net/startupapo/neu-ncleo-de-empreendedorismo-da-usp $>$ Acesso em: 29/07/2016.

STENSAKER, B.; VALIMAA, J.; SARRICO, C. (ed). Managing Reform in Universities: The Dinamics of Culture, Identity and Organisational Change. Palgrave Macmillan. 2012.

TELLES, R. A efetividade da "matriz de amarração" de Mazzon nas pesquisas em Administração. Revista de Administração, São Paulo v.36, n.4, p.64-72, out/dez. 2001

TEPPER, G. 2013. Peres envisions Middle East as 'startup region'. The Times of Israel. Disponível em: < http://www.timesofisrael.com/peres-envisions-middle-east-as-start-upregion/> Acesso em 14/06/2014. 
TORNATZKY, L. G.; RIDEOUT, E. C. 2014. Innovation U 2.0 - Reinventing University Roles in a Knowledge Economy. Innovation U 2.0. Disponível em: $<$ http://www.innovation-u.com/> Acesso em: 13/02/2016.

THIOLlENT, M. Metodologia da pesquisa-ação. São Paulo, SP: Cortez, 2011.

TIM, I. 2016. Academic Working Capital. Instituto Tim. Disponível em < http://awc.institutotim.org.br/ > Acesso em 13/02/2016.

TYLER, R. 2011. Student entrepreneurship 'matures'. The Telegraph. Disponível em: $<$ http://www.telegraph.co.uk/finance/yourbusiness/8279664/Student-entrepreneurship-

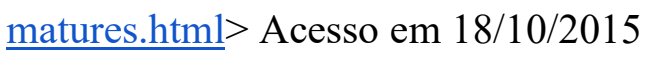

UDASIN, S. 2015. WATCH: Shimon Peres throws a paper airplane in the name of education. The Jerusalem Post. Disponível em: $<$ http://www.jpost.com/IsraelNews/Culture/WATCH-Shimon-Peres-throws-a-paper-airplane-in-the-name-of-education413706> Acesso em: 18/10/2015.

USP. 2012. Poli/USP leva suas iniciativas inovadoras ao USPiTec. Escola Politécnica da Universidade de São Paulo. Disponível em: < http://www.poli.usp.br/fr/comunicacao/noticias/arquivo-de-noticias/1066-poliusp-levasuas-iniciativas-inovadoras-ao-uspitec.html> Acesso em: 29/07/2016.

2015. Processo Seletivo NEU Startup Lab recebe inscrições. Comunidade USP. Disponível em: < http://www5.usp.br/100262/processo-seletivo-neu-startup-lab-teminscricoes-abertas/> Acesso em: 29/07/2016.

VANZOLINI, F. 2016. Fundação Vanzolini apoia Festival de Empreendedorismo da USP. Fundação Vanzolini. Disponível em: <http://vanzolini.org.br/noticia/fundacao-vanzoliniapoia-festival-de-empreendedorismo-da-usp/> Acesso em: 29/07/2016.

VELOSO, M. 2013. Equipe mineira vence competição com aviões em SP e vai representar o Brasil no exterior. Jornal Hoje em Dia. Disponível em: < 
http://cms.hojeemdia.com.br/preview/www/2.602/2.616/1.217102> Acesso em: $18 / 10 / 2015$.

VIAEPTV. 2014. Empresários criam grupo para ajudar empreendedores de Ribeirão Preto. Jornal A Cidade. Disponível em: < http://www.viaeptv.com/noticias/noticias internaNOT.aspx?idnoticia=969539> Acesso em: 18/10/2015.

WOOLLARD, D.; ZHANG, M.; JONES, O. Creating Entrepreneurial Universities: Insights from a new university business school. Institute for Small Business \& Entrepreneurship. 2007.

WRIGHT, M. et al Academic Entrepreneurship and Business School. J Technol Transf, 34, p 560-587, 2009.

YIN, R. K. Estudo de caso - planejamento e métodos. (2Ed.). Porto Alegre: Bookman. 2001. 


\section{APÊNDICE}

APÊNDICE 1 - Roteiro utilizado na entrevista 


\section{ROTEIRO UTILIZADO NA ENTREVISTA}

\section{Entrevistado:}

\section{Cargo:}

\section{Tempo de organização:}

\section{Curso:}

-Pré-entrevista: apresentar o porquê da entrevista, explicar do que se trata e solicitar permissão para gravação. Iniciar a gravação reforçando a permissão, apresentando o entrevistado e iniciando formalmente a entrevista.

Sobre a organização, pontos importantes e momento atual:

Bloco 1: O papel da universidade (e dos grassroots) na promoção do empreendedorismo

-Na sua percepção, como a universidade pode auxiliar o ecossistema de empreendedorismo da região em que está inserida?

-Na sua percepção, como uma organização grassroots pode auxiliar o ecossistema de empreendedorismo da região em que está inserida?

-(Apresentar o modelo de Lemos) Quais são os papéis que se alinham completamente com as funções desempenhadas pela organização?

Bloco 2: A criação e desenvolvimento de uma organização grassroots para empreendedorismo em uma universidade

-Comente sobre o surgimento da organização e as motivações principais dos fundadores.

-Fale um pouco sobre as atividades realizadas pela organização.

-Fale um pouco sobre os resultados já alcançados e métricas utilizadas.

-Ao longo do desenvolvimento da organização, quais os principais desafios encontrados e soluções empreendidas para tais?

-Quais os fatores críticos para a sobrevivência da organização por você percebidos?

-Quais os principais desafios sobre o futuro por você percebidos?

-Na sua percepção, como a universidade pode apoiar a organização sem tolhir a autonomia?

-Como são as relações institucionais e as interfaces com outras entidades dentro da universidade? 
-Como são as relações com outros elementos do ecossistema de empreendedorismo em que estão inseridos?

-Quais competências esperadas pelas pessoas da organização?

-Na imersão teórica, foi encontrado um ponto relativo ao papel das lideranças no desenvolvimento de iniciativas grassroots. No caso da sua organização, houve a presença de alguma liderança marcante?

Bloco 3: O modelo de maturidade proposto pela NACUE e sua aplicação aos casos estudados

(Indicadores estão em negrito para explicação ao entrevistado)

Estratégia - desenvolvimento e execução de planos estratégicos de curto e médio prazo para crescimento sustentável.

-Avaliando o indicador de 0 a 5 (sendo 0 muito pouco e 5 completamente), quão relevante é para a sua organização?

-Se pudesse fazer uma auto-avaliação, qual seria a nota da organização? Por que? Qual a métrica utilizaria? Qual seria um modelo ideal nesse indicador?

Governança - nível de profissionalismo na organização da estrutura de gestão e no corpo de conselheiros

-Avaliando o indicador de 0 a 5 (sendo 0 muito pouco e 5 completamente), quão relevante é para a sua organização?

-Se pudesse fazer uma auto-avaliação, qual seria a nota da organização? Por que? Qual a métrica utilizaria? Qual seria um modelo ideal nesse indicador?

Processos internos - efetividade organizacional, incluindo reuniões estruturadas, uso de plataformas para comunicação digital e o desenvolvimento de práticas operacionais

-Avaliando o indicador quão relevante é para a sua organização?

de 0 a 5 (sendo 0 muito pouco e 5 completamente),

-Se pudesse fazer uma auto-avaliação, qual seria a nota da organização? Por que? Qual a métrica utilizaria? Qual seria um modelo ideal nesse indicador?

Sucessão - desenvolvimento e execução de um plano de sucessão e transição de gestão que garanta a sobrevivência e crescimento da sociedade a cada ano

-Avaliando o indicador quão relevante é para a sua organização?

de 0 a 5 (sendo 0 muito pouco e 5 completamente), 
-Se pudesse fazer uma auto-avaliação, qual seria a nota da organização? Por que? Qual a métrica utilizaria? Qual seria um modelo ideal nesse indicador?

Assinatura - número de "assinantes" registrados e associados à organização, bem como o desenvolvimento e execução de um plano de marketing para diversificação da base de assinantes

-Avaliando o indicador quão relevante é para a sua organização?

de 0 a 5 (sendo 0 muito pouco e 5 completamente),

-Se pudesse fazer uma auto-avaliação, qual seria a nota da organização? Por que? Qual a métrica utilizaria? Qual seria um modelo ideal nesse indicador?

Relações internas - Força de comunicação e colaboração que a sociedade possui com o corpo-chave da universidade

-Avaliando o indicador quão relevante é para a sua organização?

de 0 a 5 (sendo 0 muito pouco e 5 completamente),

-Se pudesse fazer uma auto-avaliação, qual seria a nota da organização? Por que? Qual a métrica utilizaria? Qual seria um modelo ideal nesse indicador?

Relações externas - Força na comunicação e colaboração que a sociedade possui com a comunidade local, com os negócios locais e nacionais e outras sociedades regionais, nacionais e internacionais.

-Avaliando o indicador quão relevante é para a sua organização?

de 0 a 5 (sendo 0 muito pouco e 5 completamente),

-Se pudesse fazer uma auto-avaliação, qual seria a nota da organização? Por que? Qual a métrica utilizaria? Qual seria um modelo ideal nesse indicador?

Impacto gerado e negócios criados - desenvolvimento e execução de atividades que influenciam diretamente no suporte a empreendimentos ligados à sociedade, bem como à criação de novos negócios.

-Avaliando o indicador quão relevante é para a sua organização?

de 0 a 5 (sendo 0 muito pouco e 5 completamente),

-Se pudesse fazer uma auto-avaliação, qual seria a nota da organização? Por que? Qual a métrica utilizaria? Qual seria um modelo ideal nesse indicador?

Portifólio de captação financeira - quantidade de caixa e outros tipos de financiamento levantado, bem como a diversidade das fontes. 
-Avaliando o indicador quão relevante é para a sua organização?

de 0 a 5 (sendo 0 muito pouco e 5 completamente),

-Se pudesse fazer uma auto-avaliação, qual seria a nota da organização? Por que? Qual a métrica utilizaria? Qual seria um modelo ideal nesse indicador?

Marketing e branding - desenvolvimento e execução de uma estratégia compreensiva e coerende de marketing e brading, de modo a aumentar o engajamento de alunos de maneira sustentável

-Avaliando o indicador quão relevante é para a sua organização?

de 0 a 5 (sendo 0 muito pouco e 5 completamente),

-Se pudesse fazer uma auto-avaliação, qual seria a nota da organização? Por que? Qual a métrica utilizaria? Qual seria um modelo ideal nesse indicador?

Programação de atividades e eventos - desenvolvimento e execução de uma série de atividades que ofereçam inspiração, capacitação, aprendizagem experiencial, networking e outras oportunidades para empreendedorismo.

-Avaliando o indicador quão relevante é para a sua organização?

de 0 a 5 (sendo 0 muito pouco e 5 completamente),

-Se pudesse fazer uma auto-avaliação, qual seria a nota da organização? Por que? Qual a métrica utilizaria? Qual seria um modelo ideal nesse indicador?

\section{(Últimas questões para finalização da entrevista)}

-A partir dos 11 indicadores, elenque, do mais importante para o menos importante, os indicadores que melhor fazem sentido para o progresso e maturidade de sua organização.

(Estratégia, Governança, Processos Internos, Sucessão, Assinatura, Relações internas, Relações externas, Impacto gerado e negócios criados, Portifólio de captação financeira, Marketing e branding, Programação de atividades e eventos.)

-Quais fatores-chave você considera que deva possuir uma organização para se considerar madura? Existiria algum grau de importância para os mesmos?

Pós-entrevista: agradecer o respondente e encerrar a gravacãa. 